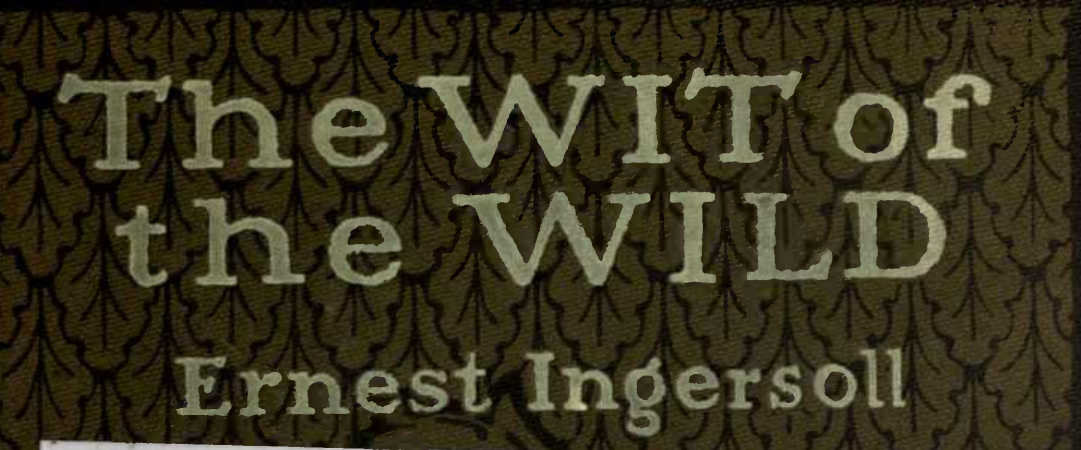
UC-NRLF

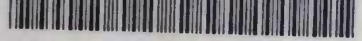
B $3 \quad 300994$ 1) IfAsidy 5)

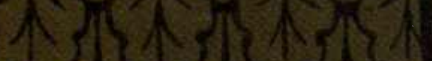
S. 


\section{The Wit of the Wild}

\section{\&}

stories alleged, yet he might almost as well do so, for the slightest touch will cause their needlelike barbed points to adhere to any soft surface, and they are pulled out and carried away by the enemy as souvenirs of a fruitless encounter far more difficult to get rid of than to acquire.

Few of the woodland animals are unaware of this, and consequently nothing but the foolishness of youth, or the desperation of extreme hunger, will lead any beast of prey to forget the warning of the rattling quills and leap upon their tender-fleshed but bristling owner. Some of the smaller ones, like the fisher marten, do, however, get him by strategy,-creeping beneath the snow in winter and seizing his unprotected throat or belly in a fatal nip. Against such an attack, by what soldiers would call "sapping and mining," the poor porcupine can make little defense.

A good many bugs and some caterpillars and crustaceans have an armament somewhat similar to that of the "fretful porcupine," but these behave more like the hedgehog, simply rolling up so that their points stand out in every direc- 


\section{Birds and Beasts that Bluff}

\section{\&}

tion and defy the enemy to find an exposed point for attack.

There is one sort of fish, however, represented by several species in Northern seas, as well as many in the tropics, which combines a strong disposition to bluff with a very good "hand." This is the tribe of globe-fish or porcupine fish, of which the little puffer or swell-doodle of our Atlantic coast is a good example.

These fishes when quiet look much like others, except that they have a rough, leathery skin instead of a scaly one, and are everywhere (except along the abdomen) covered with bristlelike appendages. Let one of them be alarmed in any way, however, and an almost instantaneous change takes place. It sucks in water by rapid gulps until it swells into a ball studded with stiff spikes. In this condition it rises to the surface of the water and spins and bobs about, giving queer audible grunts, and making a most extraordinary and to our eyes comical appearance.

This is enough to make 'most any thoughtful fish repent the error of its intention, and 


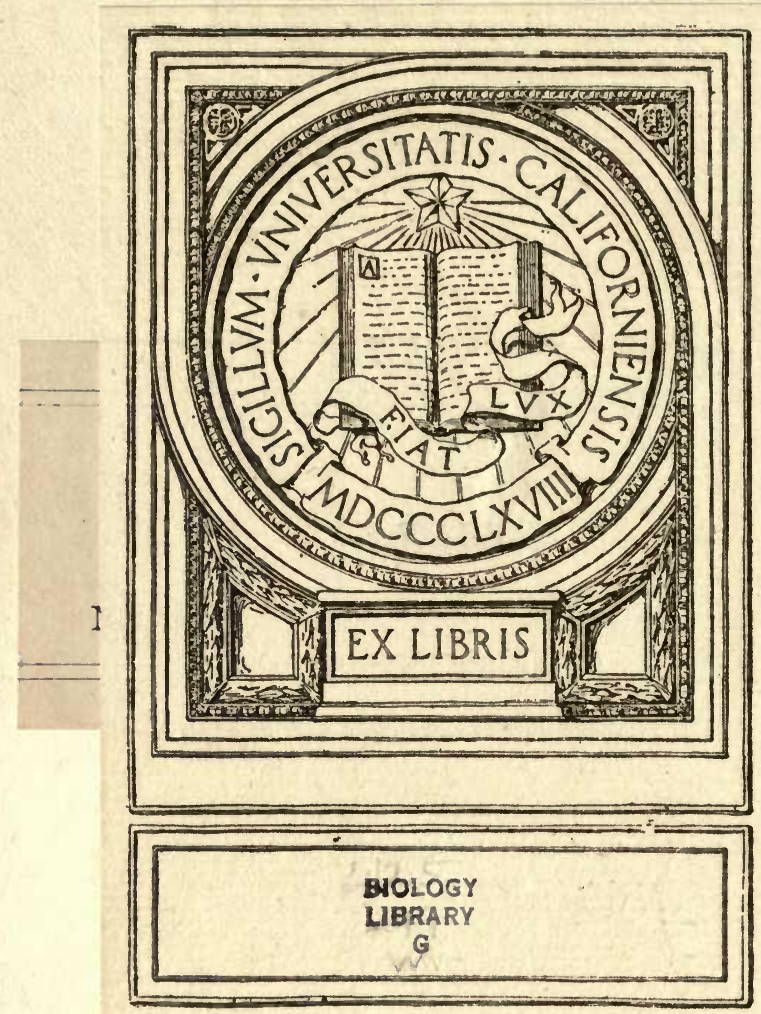


$\because 4$ 

The Wit of the Wild

$$
\begin{gathered}
\text { P.L. Ulabter. } \\
\text { 1906. }
\end{gathered}
$$





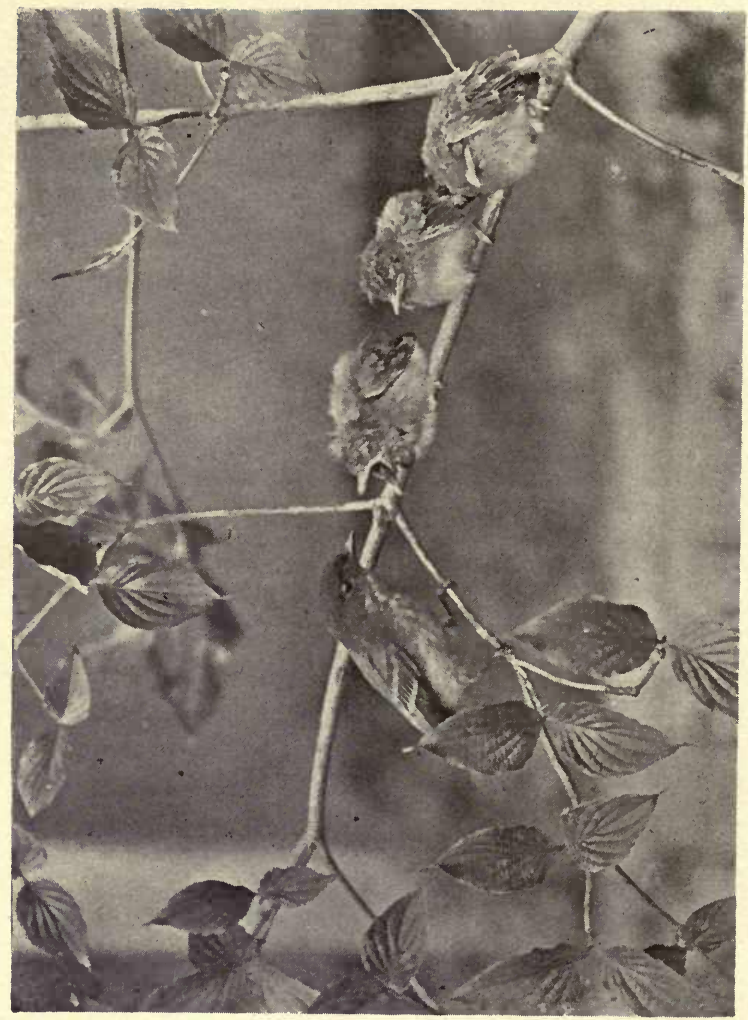

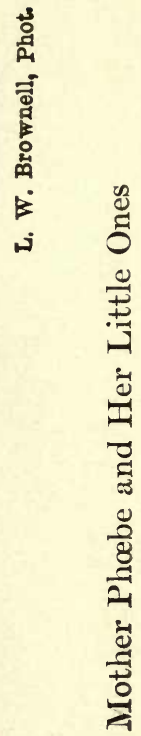




\title{
THE
}

\section{WIT OF THE WILD}

\author{
By \\ ERNEST INGERSOLL \\ Author of "The Life of Mammals," \\ "Wild Neighbors," "Wild Life of \\ Orchard and Field," Etc.
}

\section{Illustrated}

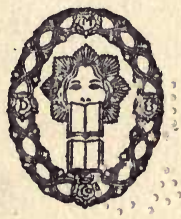

NEW YORK

DODD, MEAD AND COMPANY

1906 


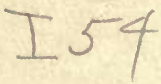

BIOLOGY LIBRARY

G

Coprright, 1906, BY

ERNEST INGERSOLL

Published, September, 1906

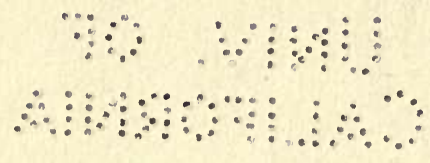




\section{To \\ HELEN \\ The Chatelaine \\ of}

Rimrocks 



\section{Prefatory Note}

\&

Tre substance of many of the chapters in this little book first appeared as articles in the Sunday edition of The World, New York; in The Field, of London, and in The Youth's Companion, of Boston; and the author acknowledges with cordial thanks the courtesy of the publishers of these periodicals in permitting him to revise and make renewed use of the material.

E. I. 



\section{Contents}

\section{\&}

The Way of a Weasel (- Pa" Madame Redbelt . . . . . . . . 13

Life Insurance for Wasps . . . . 26 The Squirrel's Thrift, and How It Was Learned . . . . . . . . . . 87 The Seamy Side of Bird-Life . . . 49 Three Tragical Bird-Romances . . . 59 A Tiny Man-o'-War . . . . . . . 70 My Snake-Stick . . . . . . 82 Animals that Advertise . . . . 102 Animals that Wear Disguises . . . 114 Birds and Beasts that Bluff . . . 122 A Good Habit Gone Wrong . . . 182 Animals that Set Traps . . . . . 141 Animal Partnerships . . . . . . 151 The Bird that Whips Poor Will . . 162 ix 5 


\section{Contents}

\section{\&}

Birds of a Feather . . . . . 186 Do Animals "Commit Suicide"? . . 196 A Turn-Coat of the Woods . . . . . 211 The Biggest Bird's-Nest and Its Maker 226 The Phœbe at Home . . . . . . 237 The Haymakers of the Snow Peaks . . 250 A Kitten at School . . . . . . 262 Catching Menhaden off Montauk . . 270 Gull Dick . . . . . . . . 281 


\section{Illustrations}

\section{\&}

Mother Phœebe and her little ones - Frontispiecs

raciNa PAGN

A squirrel in the door of his storehouse 46 Chickadee's nest in the top of a hollow. stump . . . . . . . 52 A ruined bird house . . . . . 56 Portuguese man-o'-war . . . . . 72 A copperhead, drawing himself into a coil 94 A twig-like walking-stick insect . . 118 A bluffing sphinx caterpillar . . . . 124 "That harmless braggart, the hog-nosed snake" . . . . . . . . . . 128 Two opossums feigning death . . . 134 Sapsucker work on an apple tree. . 148 Nests of wild eave, or cliff swallows . 192 The winter castle of the muskrat . . . 204 The changeable tree-frog . . . . 220 Phœebe's nest . . . . . . . . 246 "If we keep quite still, sister, he won't see us on this old gray $\log "$. . 256 of xi 



\section{The Way of a Weasel}

\section{\&}

A I was hurrying down the path past my neighbor's summer lodge, "Slab1 sides," at the edge of the rocky woods, this morning, I heard a commotion in the brush, and an instant later saw rushing across the road ahead of me a pullet closely followed by a weasel, the latter going very easily as compared with the chicken's frantic haste.

My neighbor happened to be standing by his doorstep, and, running forward to meet the pair, stamped his foot on the weasel just an instant after it had leaped upon the hen, whose gray feathers were already flying. The marauder's first stroke had had almost the deadly effect of a charge of shot, and although the pullet struggled away into the shelter of some vines (not thinking of coming to us for protection), I suspect she never got well.

Reaching down, my neighbor released and

$$
\rightarrow 1 \text { so }
$$




\section{The Wit of the Wild}

\section{\&}

lifted the weasel by the nape of the neck, and held him out at arm's length between his thumb and finger-an image of impotent rage. His head was like a round wedge, his ears lay flat back, his round black eyes glowed like jet, and the white, long-whiskered lips, flecked with blood, were drawn back from a jagged row of needle-pointed teeth, ivory-white, in a snarl that portrayed a prisoner caught but not conquered. He writhed and squirmed in the man's firm grasp, trying his best to get his teeth into the detaining fingers, and did succeed in scratching them with the nails of a paw already red with the blood of the wounded pullet.

It would be hard to make a finer picture of baffled fury than that little carnivore presented. He knew he was doomed, for he remembered other chickens he had caught and killed; and if he had acted like a coward he would simply have been drowned in the horse-trough or had his brains dashed out on a rock. But his bold spirit against overwhelming odds-his unquenchable courage-won him a nobler fate; and calling his dog my friend gave the bandit 


\section{The Way of a Weasel \\ \&}

a chance for a hero's victory or death in honorable battle.

The little weasel, not one-twentieth the weight of the terrier, accepted the challenge without a breath of hesitation. The instant he was thrown down before the dog, he faced the foe with fur on end, feet braced and jaws wide open -never a thought of running away in his plucky heart.

The terrier rushed in only to have the weasel leap straight at his open mouth and fasten its teeth in his nose. This was disconcerting, and the dog squealed with surprise and pain; but he also was courageous, and, shaking off his tormentor, seized it again, only to have it wriggle a second time out of his jaws and make a valiant effort to escape from this unequal contest. The dog darted after it and got a fresh hold, but so did his undaunted and pertinacious foe, and Nip had to whirl the weasel round and round his head, while it hung to his torn lip by its teeth, before he could shake it loose and a third time seize its body in an effective grip. Even when, crushed at last under major force, the 


\section{The Wit of the Wild}

\section{\&}

weasel lay at the point of death among the bruised and bloody weeds, an indomitable spirit still glared from the black eyes, the sharp teeth were bared as defiantly as ever in the face of his big conqueror, and it died like a hero.

These weasels, which are substantially the same as the European stoats, whose coats, turning white (except the black tail-tip) in winter, in northern countries, give us the " $\mathrm{er}-$ mine" of the furriers, are one of the few kinds of wild quadrupeds which seem not only to maintain themselves against civilization, but actually to profit by it. This they can do because of their small size, their clever wits, developed by a life of constant cunning, their hardihood and fearlessness.

Finding some cranny to their liking among the rocks or within an old stone wall, a weasel family will furnish it with bedding of dried grass and make a home as snug as it is secure. An exceedingly narrow doorway will serve them, for their loose and lithe bodies can creep through a very small and tortuous aperture, which may be defended against any enemy un- 


\section{The Way of a Weasel \&}

able to tear the place apart. A snake, indeed, is the only hostile thing (except another weasel) that can get into such an intricate den. I believe a weasel would not hesitate an instant in attacking it if it came; and I guess he would overcome the worst snake of our woods. I have never seen a battle between a serpent and an ermine, but I have no doubt the mammal, small as he is, could avoid the reptile's fangs by his leaping agility - for he is acrobat and contortionist in one-and destroy it by his lancet-like teeth.

By the same token, as Irishmen say, the animal is able to follow the mice and other of its lesser prey along their runways, and into their narrow and winding burrows and hidingplaces, careless of depth, or darkness or danger.

It is characteristic of so courageous a creature that it should be a faithful ally. A pair will stand affectionately and nobly by each other in danger, and a weasel mother will defend her young to the last gasp. I once met in the spring, in the woods, a family of minks -only another sort of weasel-consisting of a 


\section{The Wit of the Wild \\ \&}

mother and four little ones, perhaps a quarter grown. In the first surprise the mother darted under a rock, whining a danger-signal to her children, one of which I knocked on the head to add as an instructive specimen to my collection of skins; while the others, too young to understand their danger, dodged about among the leaves.

The instant I stooped to pick up the dead kitten the mother rushed at my hand, and I had to draw back quickly to escape her. She stopped at my feet and sat up on her haunches, her lips drawn back, her eyes gleaming, and every hair on end, whining and daring me to come on. I stood perfectly still, and in a minute she dropped down on all fours, and, always keeping her eye upon me-a giant to her apprehensive view-coolly began to collect her babies, and carry them off, one by one, in her mouth, to a place of safety under a rock, where perhaps was their home. A lion could not have shown more clean courage and indifference to danger than that small mink mother.

'A relative of mine, a preacher and truthful, 


\section{The Way of a Weasel \&}

relates that he was sitting in an upper room of his house at Easthampton, Mass., one afternoon, when he saw a weasel come up the stairs, enter the room and saunter about, examining everything within reach of his nose, including the parson's square-toed boots, with careful attention. Having completed this survey, it quietly withdrew, pattered softly down stairs, and the dominie went on with his sermon. Whether his visitor also went to hear the sermon, I do not know; and it is a pity, for then perhaps we should learn whether it really were possible to " catch a weasel asleep."

Ferocity marks all that the weasel does. $\mathrm{He}$ constantly kills more than he can eat, seemingly just for the joy of seizing and killing, and a pair that make their residence near a poultry-yard will destroy the flock in a short time if not prevented. They are the terror of the wild birds-one of the worst of their daylight foes, especially for the ground-keeping birds; and here again they arouse the anger of the sportsman, whose wild poultry, the quails and grouse and woodcock, they kill before he 


\section{The Wit of the Wild \\ \&}

himself can get a chance to do so with his gun. I have known one recently to conquer a halfgrown house-cat.

Thus, between their coveting the value of his fur and their vexation at his depredations upon the farmyard and the game-preserve, most men are at enmity with the weasel and compel him to be on his guard whenever he goes abroad. Yet so secretive and sly is he, so exceedingly alert, quick, and courageous, that he maintains himself in great numbers everywhere outside of towns; and even in large villages you may find his tracks on the snow on winter mornings, - " a chain that is blown away by the wind and melted by the sun, links with pairs of parallel dots the gaps of farm fences, and winds through and along walls and zigzag lines of rails," as Rowland Robinson says.

Civilization, indeed, has helped rather than hurt him and his tribe. His food does not consist altogether, or perhaps mainly, of birds, but even if it did he would be benefited by the human clearing and cultivation of the wilderness, because these bring about a multiplica$\rightarrow 0$ so 


\section{The Way of a Weasel \\ \&}

tion of the total number of birds in a locality, in spite of the fact that a few species are lessened or extinguished. But man's operations also tend to increase the total of small mammals, such as rabbits, gophers, squirrels, and mice, upon all of which the weasel preys with avidity, and none of which can wholly escape hirn, for he can race the swiftest of them with success, can pursue the squirrels to the topmost tree-boughs, though he dare not follow them in lofty jumping, and can chase into their utmost burrows those creatures that seek safety in holes or by digging. Of mice he kills hundreds in the course of a year, no doubt, and thus repays the husbandman for the chickens and ducks he steals, and he will clear a barn of rats in a short time. The chipmunk is a tidbit he is extremely fond of, and probably more of these pretty ground-squirrels fall beneath his teeth than in any other single way.

Of what, indeed, is this bold little carnivore afraid?-for fear may honorably quicken the beating of a heart where cowardice finds no residence. 


\section{The Wit of the Wild}

\&

In the New England, or Middle States, almost nothing exists to alarm him, except man and his guns, dogs, and traps. Where wildcats range the woods, he no dcubt falls into their grasp now and then, and then sells his life as dearly as possible; and that he would "die game" even within the jaws of a wolf one may be sure who has seen his sturdy, undaunted struggle with a dog. I have read and have seen pictured accounts of birds of prey having seized weasels of one kind or another that in turn fastened upon the bird's throat or body, and so were carried up into the air until they had gnawed the bird's life away, and both came tumbling to earth locked in mutual murder. It is quite possible something of this sort may occasionally happen, but I have never seen it, nor can I find any evidence of a predatory bird in this country ever having seized a weasel, even by mistake, for something easier to handle.

This animal's endowment of especial valor seems, therefore, superlative, and tending to needless slaughter and cruelty in nature. But this quality is probably an inheritance from 


\section{The Way of a Weasel \\ \&}

the distant past, when the race of weasels dwelt in the midst of a world of fighting against conditions and enemies which they have survived by means of these very virtues; and it may be that here, as sometimes happens elsewhere, virtues have changed into vices through change of exterior circumstances.

Yet this leads us into what is really a wrong and illogical position, for what we are calling vices, namely, the weasel's acts of rapacity and unnecessary slaughter, are only so from our point of view and in his relation to us.

Apart from the fact that the excessive slaughter of which we call him "guilty" may have a beneficent purpose and effect in keeping down the too rapid multiplication of mice and other noxious pests whose other natural enemies have been unduly diminished in cultivated regions, it must be remembered that he is doing only what it is the business and need of his life to do; and that we hate him principally because he becomes a rival and interferes with our own plans in the same direction. Hence the vengeful spirit in which my farmer- 


\section{The Wit of the Wild \\ \&}

friend this morning damned him and hurled him down before his dog was as illogical as it was unkind.

On the whole, philosophically considered, the difference between the weasel's acts and our own cannot be regarded as really great-at any rate to the victims! 


\section{Madame Redbelt}

\section{\&}

T. WAS sitting on the stone wall waiting for the August sun to knock off its day's 1 work, and idly watching a gray spider that had spread a gauzy net across an opening among the loose slabs, when Madame Redbelt came and sat down beside me.

I looked for trouble at once, for Madame Redbelt is a wasp, and many wasps have a habit not only of dining off spiders, but of preferring them as food for their babies, which has made hard feeling between the two branches of the insect race, from which only the most enlightened members are free. Therefore $I$ was anxious, but when I saw the visitor coolly running about underneath the web, while the gray spider peered down with languid wonder at her activity in the heat, apparently not fearing her at all, I aroused myself to sharper attention. 


\section{The Wit of the Wild}

\section{\&}

Then I saw that she was not one of the broad-winged brown wasps so numerous about this house in the edge of the woods, but a slender, thread-waisted one, exceedingly active afoot, and carrying her wings like two slats along her back; in fact, each was folded up like a fan of three sticks.

Right behind the flexible rod of a waist, where the body swelled again, was a bright red band; and so I called her Madame Redbelt, for I did not then know her book-name, which is Ammophila urnaria. You may read scientific history of her, if you wish, in that fine treatise, "The Instincts and Habits of the Solitary Wasps," by George W. and Elizabeth G. Peckham.

A wide crack in the top of the wall, under the web, was filled with dry earth in which a few small weeds grew, and this tiny garden seemed greatly to interest the little lady, who darted hither and thither examining every inch.

Suddenly she halted and began to scratch with her foremost feet, sending the grains of 


\section{Madame Redbelt \\ \&}

sand flying backward and deepening a hole precisely as does my fox-terrier Waggles when he hopes he has found the hiding place of a chipmunk.

In a minute or so she changed her method and began to dig with her jaws. She would scrape down a quantity of earth, gather it into a bundle between her chin and elbows, so to speak, and then backing out, would carry it well back from the entrance and fling it away with a quick flirt, as though glad to be rid of it. Now and then she would pause and choose where she would next drop her load, or stop and push away the loose earth to prevent its rolling back toward her trench, and all together her movements were most human and interesting.

I leaned down close to her without her caring, yet every few minutes she would stop work and walk all about her narrow domain, and sometimes make short flights here and there, as if to make sure no danger were near; but these halts were brief, and at the end of twenty minutes or so she had almost disappeared in her excavation-just the tip of her body with 


\section{The Wit of the Wild}

\section{?}

its sting showing at the top of the ground, and two hind feet clinging to the surface.

Now it was plain why her wings were folded so snugly on her back-the ordinary shape would never do for a miner, like this industrious little lady.

She worked on as hard as ever, bringing up earth and pebbles, piling them in a ring around her, and then diving after more; and all the time she sang a low, contented, humming song which told of hope and joy. Why not? She was constructing a home-a place for her babies, where the first object of her existence, the limit of her desire and ambition, should be satisfied. The sun shone, the ground was dry and warm, no parasites were near to make her anxious nor enemies to alarm her. Why shouldn't she sing of her content and gladness?

For some time then I noticed that she went no deeper, so I concluded that she was hollowing out a chamber at the end of her sloping drift, and I was right.

It was just half an hour by the watch from os 16 so 


\section{Madame Redbelt \\ \&}

the time she began (5 p.m.) until she quit digging. Then Madame Redbelt looked tired as she shook and brushed the dust from her black satin dress and sauntered out into the sunshine to rest a while.

But this was only the first stage of her proceedings. Soon she was running about with her head down, evidently in search of something. Every pebble she came to she would measure with her feelers, as a workman uses a pair of calipers. Presently one seemed to suit her and she picked it up in her jaws and trotted off in great haste. Now, try to lift a stone twice as big as your head and you will appreciate the strength of this tiny miner, who carried her burden in her teeth a good deal easier than you could carry a proportionate weight in your arms-indeed, you could scarcely lift a proportionate weight.

Running straight to her hole she dropped the pebble into its mouth, where it lodged neatly in the funnel-shaped top, forming a plug, or cover. I could see, however, that a crevice remained at one side, and Madame Redbelt saw 


\section{The Wit of the Wild \\ \&}

it, too, and at once found a smaller pebble with which to stop the gap.

Then turning her back she scraped over the stones a quantity of loose earth until all traces of a hole were concealed. And now, having shut and locked her door, Madame Redbelt ran 'round and 'round as if to make sure nobody had seen her do it, and then flew away.

I sat watching until dark. Every half an hour or so the owner came back, looked at her property and left it untouched. Then I put some bits of leaf on the spot, so that I might know of any disturbance, and said good-night.

Next morning (the 28th) the leaves had been thrown aside, but I saw nothing of Madame Redbelt until late afternoon, when she half dug another tunnel, close by the first one. This she finished on the 29th, but I did not see her again until the third morning (30th) about eight o'clock (when the sun first reached that spot), when I found her busily closing a new nest between the other two. She put into it a pebble that nearly filled it, then slowly packed armfuls of clay, bits of stick and stone over it, 


\section{Madame Redbelt \\ \&}

forcing the latter well into the ground. Often she would try a bit that would not fit the place to her liking, and it was amusing to see her toss it aside with an impatient gesture, just as a man does when choosing proper stones for a wall.

She was very suspicious now, and at my least movement would dart away, but quickly return.

It was ten o'clock when she finished filling in the nest, and then she departed for half an hour as if to rest, and probably to get a drink, which such wasps take frequently. In her returning, by the way, she almost always arrived from a certain direction and first alighted on a particular stone, where she cautiously surveyed the land before going in a roundabout way to her holes.

At 10.30 a.m. she began a fourth tunnel within an inch or two of the others, and worked at it with feverish haste, often lying on her back to dig, until the chamber was completed, as before, in just thirty minutes.

She then went out upon a warm stone and quietly rested for a few minutes, then ran away 


\section{The Wit of the Wild}

into the grass, but by 11.20 she was back again and carefully examining every nook and corner of her estate, now and then entering and repairing the two open holes. Her movements were quick and cautious, and my least change of attitude alarmed her, whereas when she was digging she seemed careless of my presence; and soon she disappeared, leaving the last tunnel quite open. This, I fancied, was because she had been unable to find any suitable cork, so I gathered a few little pebbles of about the right size and laid them near the nest, when to my dismay one rolled halfway down the sloping tunnel.

Now that her quarters seemed prepared something interesting was likely to follow, so I got an umbrella and stayed in the hot sun to see what it might be. A half hour of patience met its reward. Suddenly Madame Redbelt alighted upon the accustomed stone, astride of a smooth, yellow caterpillar, gripped near its head in her jaws.

I have never been able, among the rocky ridges here, to follow and watch an Ammo- 


\section{Madame Redbelt \\ ?}

phila catch a caterpillar, but I know from what others have seen how it is done. The capture may be made so far from the nest that an hour or more must be spent in bringing home the prey.

When the wasp finds a caterpillar she springs upon it and a fight for life begins. The poor worm leaps and curls and thrashes about, using every art and weapon it possesses, but to little avail, for the wasp, striding over it and seizing its head in her jaws, drives in her sting until movement ceases and the caterpillar lies outstretched and quiescent. Sometimes a single thrust of the sting suffices, the poison acting like an electric shock; sometimes seven or eight stings are given into several segments.

It all depends upon whether the wasp pierces the central nervous system, which runs along the ventral side of the caterpillar in the form of a cord thickened into a "ganglion" in each segment. Some kinds of wasps seem to know how to strike certain ganglia every time; and this wasp, lifting the larva from the ground so that she may curve the tip of her abdomen underneath it, seems to try to do so, but she is

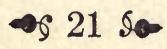




\section{The Wit of the Wild \\ s}

by no means sure in her aim. When the victim has become limp and quiet (though perhaps not dead, but only paralyzed), the wasp usually squeezes its neck in her jaws until that part is thoroughly crushed.

Now, what does she want of the caterpillarwhy all this labor and trouble? Because a caterpillar, in her instinct-opinion, is the only thing suitable upon which to lay an egg that needs to be packed away in the earthen chamber so carefully prepared for it, in order that it may hatch in safety; and also because the larva thus to be bred must have food ready for it.

Having subdued her prey, the wasp stands over it lengthwise, picks it up by the neck in her jaws and partly carries, partly drags it, going quickly or slowly according to its weight and the difficulties of the way; and if you interfere she will let it go and fight, but afterward hunt up the lost prey and continue the journey.

No animals have a better sense of locality and direction than the wasps and their relatives, the bees. It is plain that they study the place 


\section{Madame Redbelt \\ $६$}

where their nests are, familiarizing themselves with all its features. Any disturbance of these is sure to be noticed; but experiments designed to ascertain how much of their behavior in this respect arises from discriminating memory and intelligence have had varying results.

Prof. Jacques Loeb tells how an Ammophila laden with a caterpillar too heavy to lift off the ground went around the wall she was accustomed to flying over and worked her way afoot to her nest by an unknown route, then betrayed much stupidity because the hole had been concealed by a clover-blossom. But other individuals have been more clever at detecting deceits practiced upon them by inquisitive naturalists.

Madame Redbelt carried her captive to the mouth of the fourth hole, and, letting it drop, hastily entered the nest, where she at once ran against my fallen pebble, and pulled it out without more ado.

Doubtless she thought it a mere accident, not noticing, or caring nothing for, any odor of my hand that may have lingered about it. 


\section{The Wit of the Wild \\ \&}

This done, she seized the lifeless caterpillar by its head and dragged it backward into the hole, humming a song of success the while. For a whole minute she stayed there, doubtless engaged in producing and affixing an egg to the caterpillar's abdomen as it lay coiled in its sepulcher.

And as the captor came out and excitedly crowded stones and sticks and lumps of earth down the cavity, and finally scratched over it the hiding dust, I pondered upon the strangeness of this arrangement-its careless cruelty and boundless sacrifice of the present for the sake of a future the exact and diligent worker would never share-perhaps never see. For the worm is buried there to serve as food for the larval wasp that, some sixty hours hence, will be hatched from the egg and find itself fiercely hungry.

Sometimes this wasp will take a pebble in her jaws and with it pound and smooth the surface of the hidden pit, the better to destroy traces of digging.

Since that afternoon I am not sure that I 


\section{Madame Redbelt \\ \&}

have seen Madame Redbelt. Now and then, it is true, I catch a glimpse of an Ammophila flitting about the stone wall, and perhaps it may sometimes have been she, who rememberswhy not? - the very hot days and the gray spider overhead, and the colossal figure that so strangely scrutinized all the work in the tiny triangular garden where her hopes lie buried, and who anxiously watches for their fulfillment. 


\section{Life Insurance for Wasps}

\section{\&}

【1

IFE insurance is an arrangement by which the results of a person's labor may be stored up for the benefit of others who are to come after him. This is supposed to be, and is, among men, a device of modern and the most civilized society, but it has been practiced in effect by certain animals ever since they came to be what they are.

The best examples of animal life insurers are to be found among those wasps and bees which are called "solitary," because they do not live in companies, making combs or cooperative nests in which the young are reared from the egg and cared for until they are grown, which is the custom of the "social" hymenopters.

The solitary wasps, on the other hand, arrange single chambers of one sort or another in which one egg is laid and provision is stored 


\section{Life Insurance for Wasps \\ \&}

ready to be eaten by the young one that will develop from the egg, and which must spend a considerable time in the confinement of its nursery before it has grown big enough to go abroad. This custom involves some of the most ingenious arrangements and most wonderful instincts in the whole range of life.

For example: Last August $I$ found in the edge of the woods an old pail, on the inside of which were plastered structures of dried mud which looked as if they had been made by braiding clay cords into miniature imitations of halfround drain tiles. Each was as broad as my finger, with walls rather less than a sixteenth of an inch in thickness, and there were five or six side by side, the longest measuring some six inches, and containing five compartments of equal length, separated by thick cross-partitions of clay.

These were the safety-deposit vaults of a large black mother-wasp, in which she had left her treasures for the use of an assignee yet unborn. I recognized them because I had been watching for a fortnight a similar mud-wasp 


\section{The Wit of the Wild}

\section{\&}

building and filling similar treasure-houses under my porch roof. The main difference was, that while this black wasp of the woods spread its cells out flat, the blue ones in the veranda piled theirs into a heap, and finally hid the heap and protected it from enemies under a general rough coat of mud.

As soon as the really warm weather of summer arrives each of these wasps (all of which are fertile females that have survived the winter by hibernating in some snug retreat, and have been spending a month or two in elegant leisure sipping nectar and getting other dainties) feels that the time has come to lay her quota of eggs, and begins to build cells of mud, each just big enough to contain her own body.

Their skill in fabricating these out of pellets of clayey earth, mixed with saliva and drawn out by the complicated mouth-organs into ribbons of glutinous mud as they are laid on, is admirable, but not so surprising as what follows:

As soon as the cell is finished the fresh open end is usually closed by a temporary dab of 


\section{Life Insurance for Wasps}

\section{\&}

mud, to exclude strangers and mischief-makers, and the wasp goes hunting-takes out its first policy of insurance for the benefit of the intended occupant of this domicile.

Before long, if she is fortunate, she finds a spider. What is its name does not matter, nor does its size, so that it be not too large; but big ones are sometimes sheared of legs or dismembered in order to be made manageable. She darts at it, whereupon the spider probably drops like Newton's apple, by which ruse it may escape, or it may not. If it fails to drop quickly enough or far enough the wasp catches it in her jaws, drives in her sting once or twice, and carries it off in the grasp of her mouth and forefeet-not, however, directly to her home. Instead, she first alights on some convenient perch and there rolls her captive about until she has it in a position she likes, and then stings it once, deliberately and forcibly. This done she picks it up, takes it home and stuffs it down into the bottom of the cell. Then she rushes away for another, seeking one of the same kind as a preference, but if they are scarce catch- 


\section{The Wit of the Wild \\ \&}

ing any other spider not too large for her usenone are so big as to scare her. Thus in two or three hours of a July afternoon she will pack solidly into her cell ten to twenty spiders, big and little, until at last it can hold only one more.

Having caught this last one, the wasp pauses on her threshold and performs the crowning act for which all that has gone before has been simply a preparation. She deposits and glues a single egg upon the abdomen of this latest victim, and then crowding it on top of the rest, concludes her labors by bringing mud and sealing the chamber as tightly as possible.

This done, she goes her way and leaves her venture to its fate, but next day she builds and stocks a second chamber close beside it, or in continuation of it, and so on until her number is complete.

Responsibility for her young ceases with the mother's insurance to them of shelter and food until they " come of age."

Now, what happens in that dark cell? Well, in two or three days, depending on the tem- 


\section{Life Insurance for Wasps \\ \&}

perature, the egg hatches, and a tiny white grub emerges, which at once begins to feed upon the nearest spider, eating the soft parts first, then proceeding to the next, and so on, taking the tidbits of its store first, and eating the harder parts later. By this time ten days have passed, and the grub has grown nearly as big as its room. It feels, then, that the time has come for a change, and spins about itself a capsule-shaped cocoon of glutinous silk, in which it slumbers quietly for several days as a chrysalis until perfected.

Then it wakes, bursts its cerements, gnaws a hole through the clay walls of its nursery prison, and emerges into the world as a brilliant wasp. It is at first limp and hardly able to fly, yet it knows perfectly well how to sting you if you arouse its easy anger.

Now this simple story is really a marvelous one when you ponder its details. 'The motherwasp was born the previous summer, too late to see the method of building the adobe houses. So were all her companions. There was no one to teach her architecture, nor to suggest the 


\section{The Wit of the Wild \\ \&}

proper time and place, or even the need for doing such work. Yet at just the right season the insect collected the materials - a pretty thing to watch-and accomplished her task as neatly and effectively as had her dead-and-gone mother and grandmothers, themselves guided only by that inborn knowledge we term instinct.

Such an instinct has many parallels among animals, which know intuitively how to make homes for themselves or nests for the care of their young; but what shall be said of the next move? How can the wasp foresee (if she does) the end of all preparations-a history to come in which she will take no part? Why must she lay up spiders, and only spiders, while other wasps are content with nothing but flies, and still others with caterpillars, or plant lice, or something else?-for the methods and the provisions are almost as various as the species.

And here comes in another most extraordinary feature. Many wasps do not, except by accident, kill their prey. After catching them they sting them with such consummate art in certain nervous centers that they are not 


\section{Life Insurance for Wasps \\ \&}

killed, but paralyzed, and so are packed away alive and remain fresh during the many days when some of them are awaiting the use of the grub.

One of the most conspicuous examples of this is the European mud-dauber, and that insect always attaches its egg to the first spider-the one stowed away in the furthest end of the cell, so that when the grub begins to eat it devours first the oldest provisions, while those kept to the last are the freshest. Our own mud-wasp does not seem to use this paralyzing method.

Three-fourths of its spiders are killed outright and dry up in the store-house; nor does our wasp lay its egg until the last spider is put in, by which plan it escapes a large risk from destructive parasites.

We do possess certain wasps, however, which paralyze their prey rather than kill it as often as they can. One of these is the largest of our wasps-a great golden fellow, half as big as a humming-bird, which digs a tunnel in the ground, which I have sometimes found to be three feet long, and deposits in a chamber at 


\section{The Wit of the Wild \\ \&}

the end a single cicada, as big as my lady's thumb, with an egg safely tucked under its thigh.

This cicada is always buried alive, and remains comatose until the wasp-grub it carries hatches and begins to devour its vitals; and it finally succumbs to this horrid vivisection.

Another example of paralyzation stinging is found among the potter-wasps, a common kind of which in this country makes little jugs of almost microscopic grains of quartz solidly cemented by its own saliva. Like the graceful Ammophila, whose burrows are to be seen in almost every garden, it invests in an insurance in caterpillars, only in this case they must be wee ones, for the jug is not so large as a thimble and often is balanced upon a twig.

The French entomologist, Fabre, disclosed the very curious secrets of this race. With great care he opened a window in the side of the jug, so that with a magnifying glass he could see what was going on. By repeated observations he thus discovered that it was half full of caterpillars, all of which showed more 


\section{Life Insurance for Wasps \\ \&}

or less life. The egg had not been laid by the mother-wasp on one of these captives, as usual elsewhere, but had been suspended by a gossamer thread from the apex of the chamber. When the grub hatches, it, too, hangs by a thread, attached to a sort of ribbon, whence it reaches down and takes a bite from one of the caterpillars, which squirms under the infliction.

A mere stir is not attended to, but if the half-benumbed worm is aroused enough to rear its head and thrash about the grub pulls itself up by the thread and glides into the " ribbon," which is hollow (for, in fact, it is the abandoned egg-shell), and forms a refuge from the fury of the paralyzed, but not wholly inert, caterpillars. When it gets larger, the larva drops down and feeds at will, regardless of the writhing of its food.

This wonderful system of insurance for the benefit of their children, of which a great variety of further examples may easily be found and studied during the summer all over the United States, is the outcome of the growth 


\section{The Wit of the Wild \\ i}

of instincts that have been perfected through unnumbered ages by means of natural selection-instincts that, on the whole, are perhaps the most complicated and surprising in the world. 


\section{The Squirrel's Thrift, and How it was Learned}

\section{\&}

$\mathrm{O}$ NE of the poetic and pleasing incidents of autumn in the woods is the eager industry of the squirrels in gathering and carrying to their habitations quantities of nuts, acorns, rose-hips, grains of corn, and other dainties. We say they are "storing food" for the winter, and we know that the mice beneath the meadow grass, the beaver in his forest-girt pond, the weasel within the stone wall, and now and then a woodpecker or jay, are taking similar precautions against a coming season of scarcity.

The poets and moralists long ago took this incident to heart, more or less incorrectly; but, so far as I can recall, the philosopher has not considered it, nor offered any explanation of what is in reality a remarkable phenomenon. 


\section{The Wit of the Wild}

\section{\&}

We speak lightly of an animal foreseeing the winter, and even of having prophetic knowledge of what its character is to be. Proverbial weather-lore is founded on this popular faith, as witness such sayings as that the muskrats build their houses twenty inches higher and far thicker before early and long winters than in view of short and mild ones; and that chipmunks store a larger supply of nuts than ordinary in anticipation of a hard winter. Perhaps nothing in folk-lore is more fixed and widespread than this class of beliefs, despite the discouragement of many adverse statistics. Yet what evidence have we that any one of the small mammals or birds that interest us at the moment have any conscious anticipatory thought of winter ahead, or a conception of winter at all? The associative memory of older and superior animals may bring back from time to time a recollection of the last or previous ones, but we can hardly suppose that these mice and squirrels-many too young to have seen snow and ice-have any realization of the fact of the succession of seasons, or are able to rea- 


\section{The Squirrel's Thrift \\ \&}

son out with conscious intelligence that the scenes of a twelvemonth ago will surely be repeated-that again, by and by, the green leaves will change to brown, the flowers and fruits will wither and fall, the soft odorous earth and rippling water will turn to stone, and the world become a place of starvation for squirrels unless they bestir themselves.

Any one who stops to consider the little beasts, and measures how much knowledge, experience, and brain-work are implied in their alleged "foreseeing," must conclude that it is very unlikely the squirrels have any perception of the facts at all, much less a superhuman capability of knowing what is to be the next season's particular character and of providing against it. If this is so, it follows that the apparently careful, and certainly effective, provision of shelter and food which so many of them make previous to the descent of winter, is an automatic performance-the result of an instinctive impulse wholly independent of foreknowledge or any anxiety about impending scarcity. The fact that in some of its higher 


\section{The Wit of the Wild \\ \&}

manifestations a good deal of intelligence seems to be exercised-the curing and garnering of its hay by the pika, for example-is not at all incompatible with this view of the case.

That this view is right seems plain, and an alteration of circumstances would, no doubt, prove it; for should a sudden change of climate by obliterating winter remove all need of their exertion, the rodents would doubtless continue for hundreds of years to come to heap up stores in the season of abundance, just as that oldfogey woodpecker of southern California still hammers hundreds of acorns into holes in the bark of sugar pines preparatory to a time of scarcity which no longer arrives, so that the bird of the present day will never need nor care to make use of a single one of its treasures. The European hamsters toil to lay up astonishing masses of grain underground, not a tenth of which, it is said, do they eat, because now they sink into the cold trance and sleep for months beside their almost untouched stores. Here, as in the case of the opossum, elsewhere described, an instinct has overshot its mark, 


\section{The Squirrel's Thrift \\ \&}

and a heritage once essential has become an affliction to each new generation.

In northern countries, however, the majority of mice, squirrels, gophers and the like, are still face to face annually with famine, and must starve to death or create a hoard of food against that contingency. Nor can the matter be left to individual precaution. Chipmunks and pocket-mice are irresponsible folk, and could hardly be trusted to look out for themselves in so momentous a matter. How, then, has Nature impressed upon their giddy minds the necessity for the "foresight" we admire, and kept them faithful in execution of the idea? It appears to me that the beneficial habit of doing what they must do, if they are to survive in our cold climate, has been inculcated in some such way as this:

It is the natural custom of most small animals, not mere grazers or flycatchers, to take as much of their food as they well can to some favorite eating place. This trait is noticeable in a wide range of creatures-ants, bees, crabs, crocodiles, crows, fruit-bats, monkeys, certain 


\section{The Wit of the Wild \\ \&}

carnivores (notably the fox), and a large number of rodents. One finds all along streams frequented by muskrats heaps of mussel shells, and other refuse, indicating where day after day the musquash has brought his catch and dined. Little hillocks and stumps are favorite refectories, perhaps because they afford an easy outlook; and I have given in my Life of Mammals* a photographic illustration of such a dining-room on and about a stump beside a stream.

This practice may be followed from various motives, such as the wish to be alone so as not to suffer robbery between bites, or to be in a suitable place to lie down and sleep at the end of the meal. In the case of flesh-eaters-the beasts or birds of prey-there is added to this, at any rate in the season when their off spring are young, the impulse to carry some of the plunder to the family.

Now, one of the strongest feelings animating animal conduct is the desire to do things by

* The Life of Animals: the Mammals. The Macmillan Company, New York, 1906. 


\section{The Squirrel's Thrift \\ \&}

rule, to go accustomed rounds and repeat acts and operations in precisely the same way, the intelligent recognition of which is the secret of the good hunter's success.

... Use and habit are powers

Far stronger than passion in this world of ours,-

even among the wild rangers of the woods and fields. Hence the habit of seeking the same place, for an often-recurring necessity or function is quickly confirmed. Wild horses and the African rhinoceros, for example, are said to go daily to certain spots to leave their dung until a large heap forms. I have observed that dogs in the country have a similar regularity.

If this tendency is well marked in animals more or less nomadic, and whose residence in a locality is temporary, how much stronger and more noticeable will it be in the case of an animal with a permanent abiding-place, as a resident bird like the fishhawk, eagle, or rook, whose nests are occupied year after year as well as more or less continuously between breeding seasons. In the British rook, for example, 


\section{The Wit of the Wild \\ \&}

and in the jackdaw and other birds of the crow tribes, this habit leads them not only to accumulate a quantity of edible things in and about the nest long after the young have left it and are taking care of themselves, but to pick up and deposit there any bright object which attracts their restless eyes and minds.

But still more conspicuous examples of the power of habit in regulating the routine of daily life are to be found among those smaller mammals, mainly rodents, which have acquired the habit of making and living in permanent burrows, or in such houses as that of the beaver. These animals, almost without exception, are feebly endowed with powers either of defense or of escape outside their habitations, and when gathering their food (seeds, bark, etc.) they are in constant terror of enemies. They must be as quick about the task as possible, and cannot stop to eat much out there, but must merely gather what they can carry, and hasten to the safety of their doorways, at least, so as to be able to dodge back into harbor at the first alarm. This is the reason why surviving species

$$
\infty 445
$$




\section{The Squirrel's Thrift}

\section{\&}

of such animals have mostly acquired capacious cheek-pouches in which they can transport a fair supply of food to be eaten at leisure.

During the larger part of the year the pickings are scanty, and these mice, gophers, and the like, are driven by hunger to seek and try to save every bit of nutriment they can find; and some seem to be imbued with so much anxiety, or such superabundant restlessness and energy, that they bring to their homes quantities of things not edible, as well as far more food than they are able to eat. The well-known habit of the South American viscacha, as described by Darwin, Hudson, and others, of dragging to its burrow bright pebbles, flowers, lost trinkets, and all kinds of orts and ends, strikingly exhibits this sort of a disposition; and the crow tribe the world over is noted for miserly propensities-witness the sacrilegious jackdaw of Rheims.

Now, in some cases this secretiveness may redound, quite unintentionally or unexpectedly on his part, to the benefit of the busybody, and in that case would be likely to increase in effec- 


\section{The Wit of the Wild \\ \&}

tiveness. Thus, as has been intimated, the European rooks heap up in their old nests piles of acorns, bones, potatoes, and whatnot, which they find on the ground in the fall and do not care to devour at the moment. Should the winter weather set in with unusual severity, and these birds find themselves unable to obtain their natural insect food from the frozen ground, their hunger leads them to peck at the stuff they have left lying in the old nest, which continues to be a sort of headquarters for each family group. If the hard weather long continues the savings will be mostly or wholly consumed. Should the season be open, however, the purposeless "stores" will scarcely be touched, and when the time of "spring cleaning" arrives, in preparation for a new brood, the neglected and decayed accumulation will be cast out.

In the case of the store-saving mice, hamsters, squirrels, and beavers, necessity and advantage have led to a more advanced development of the habit, until finally it has become an instinct necessary to the preservation of the 

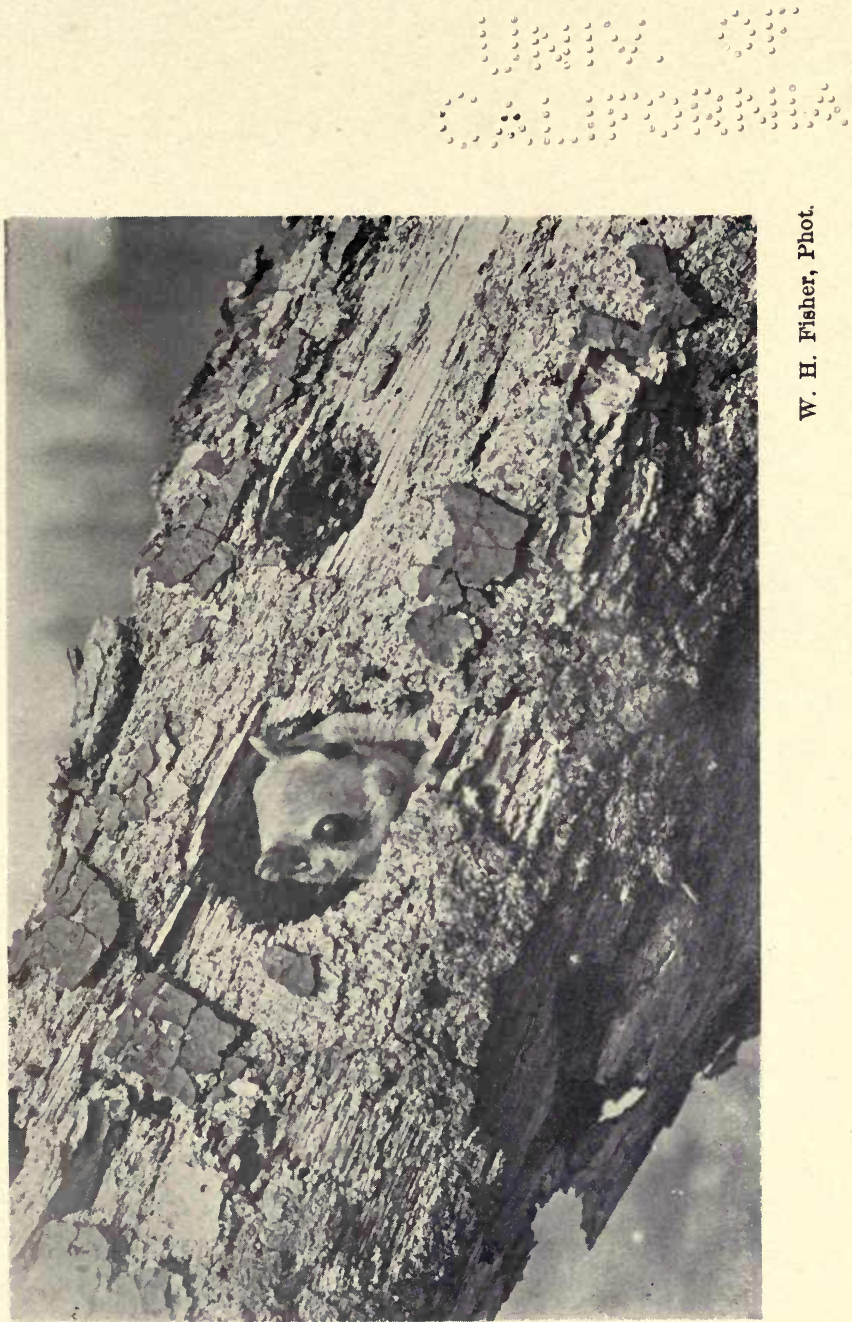

苛 


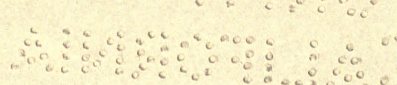




\section{The Squirrel's Thrift}

\section{\&}

species. One may reasonably infer the process of acquirement of this instinctive habit to have been something like this: Remembering that the restless search for and eager utilization of food constitute the foremost characteristic of these little animals, we may believe that this activity would be increasingly stimulated as the ripening season of the seeds, nuts, etc., on which they depend, advanced; and the acquisitive impulse urging them to incessant industry, so necessary during the poorer parts of the year, would then be over-excited and over-worked, and each animal in its haste to be up and doing would constantly bring to its home much more food than would be daily consumed, so that a lot of it would accumulate in the accustomed diningroom, which, in the case of the burrowers, is mostly a chamber underground, especially after the weather begins to grow too inclement in the autumn to make it comfortable to eat out of doors. In the ensuing winter the gradual failure of outdoor food-resources, and the growing drowsy indisposition to go abroad, which more or less incapacitates most small animals at this 


\section{The Wit of the Wild}

\section{\&}

time of the year, would lead to the utilization of those supplies casually saved in or near the burrow or house.

The animal which had been most busy, indefatigable, and clever in gathering food would then be the one having in possession the largest amount of these leavings of his autumnal feasts. Having the most food, he would be among those in the colony or neighborhood most likely to survive, and to perpetuate in his descendants the industrious qualities which had been his salvation. He would probably also be one of the strongest and fattest of his kind, and hence in general more fit to stand the strains of existence.

The action of natural selection would after due time increase in the line of descent from such an ancestor the transmitted greed for gathering food in the fall, until, quite unknown to itself in each passing individual, and, therefore, implying no creditable virtue of character, the mere busybody of old times would develop into our model of thrift. 


\section{The Seamy Side of Bird-Life}

:

T DO not know how many song-sparrows there are in this township-say one hun1 dred pairs for a guess. Each of these will lay on an average five eggs every spring. If all the eggs of every pair hatched and the young survived, we should have next year two hundred and fifty pairs, supposing all the parents to have died. The second year a similar success would furnish us with twelve hundred and fifty pairs, and the third year our township would contain over twelve thousand song-sparrows. So the increase would go on, by larger and larger leaps, until soon the hosts would hardly have room to fly, not to speak of finding food.

Experience shows that no such a thing happens. The census of song-sparrows, and of all other birds, remains about the same, showing that the births only equal the deaths.

\section{or 49 soc}




\section{The Wit of the Wild \\ \&}

Assuming that the average life of one of the woodland songsters may be five years, one-fifth perish annually, and only one in five of the eggs or young survives, or needs to do so, in order to replace the mortality. As a matter of fact, however, the proportion of eggs and nestlings saved is less than one in five, for most small birds attempt to rear two or sometimes three broods a year, and, moreover, the breeding lives of many pairs may continue through several seasons. It would not be too much to say, then, that for every success the birds of our fields and woods suffer seven or eight failures. In some classes the proportion is greater, in others less. Many seabirds rear chicks from nearly every egg they produce, so safe are the conditions surrounding their nesting life.

Now, this mortality is not equally distributed. Birds do not find a part of their eggs infertile, nor do a part of each set of nestlings die, so that each family loses some and saves some of its offspring, but ordinarily they succeed wholly or else wholly fail in respect to each brood; and every such failure is tragic, how- 


\section{The Seamy Side of Bird-Life \&}

ever much utility it may serve, secondarily, in providing some other creature with needed food. Bright and lissome, gay and careless as our birds seem to be, their lives are burdened by dread, and that which should be the most joyous season is most frequently fraught with sorrow.

Yesterday, for example, we found dead in the road a fledgling, beaten down, chilled and destroyed by the cold rains that for two or three days have pelted the earth. Undoubtedly many such an accident has happened, and it is probable that in hundreds of nests the young have been drowned, or chilled, or starved to death by this same unseasonable storm.

I remember that once a foolish chickadee nestled in the top of a hollow stump, where her chamber was a perfect pocket, and while she was sitting a tremendous rain fell. I am sure her brood would have been drowned in their bed had I not thought of them and fixed a temporary pent-house to shield their domicile.

Long-continued rains do immense damage to the robins' early mud-built nests by melting 


\section{The Wit of the Wild \\ \&}

them down, and that is probably the main reason why this bird so persistently seeks the shelter of our porches. The cliff swallows, too, suffer in that way in wild regions, where they plaster their earthen bulb-like homes in dense colonies on the face of a cliff or clay bank, whence I have seen them slough off by the score when dampened; but they, too, "know enough to come in when it rains" and wherever civilization has gone they have abandoned their precarious native method for nesting sites beneath the eaves of barns and have even modified their architecture in adaptation to the new and safer positions.

Gales sometimes upset nests and hurl them out of the trees, though this is not so frequent an accident as one might expect. Sometimes, however, birds place their nests most insecurely. A robin last summer built a nest near me in a clump of maples, and was so foolish as to rest it upon two near-by branches, one of which belonged to one tree and one to another. Of course the first high wind, moving the trees at variance, wrenched the nest apart. I saw a 


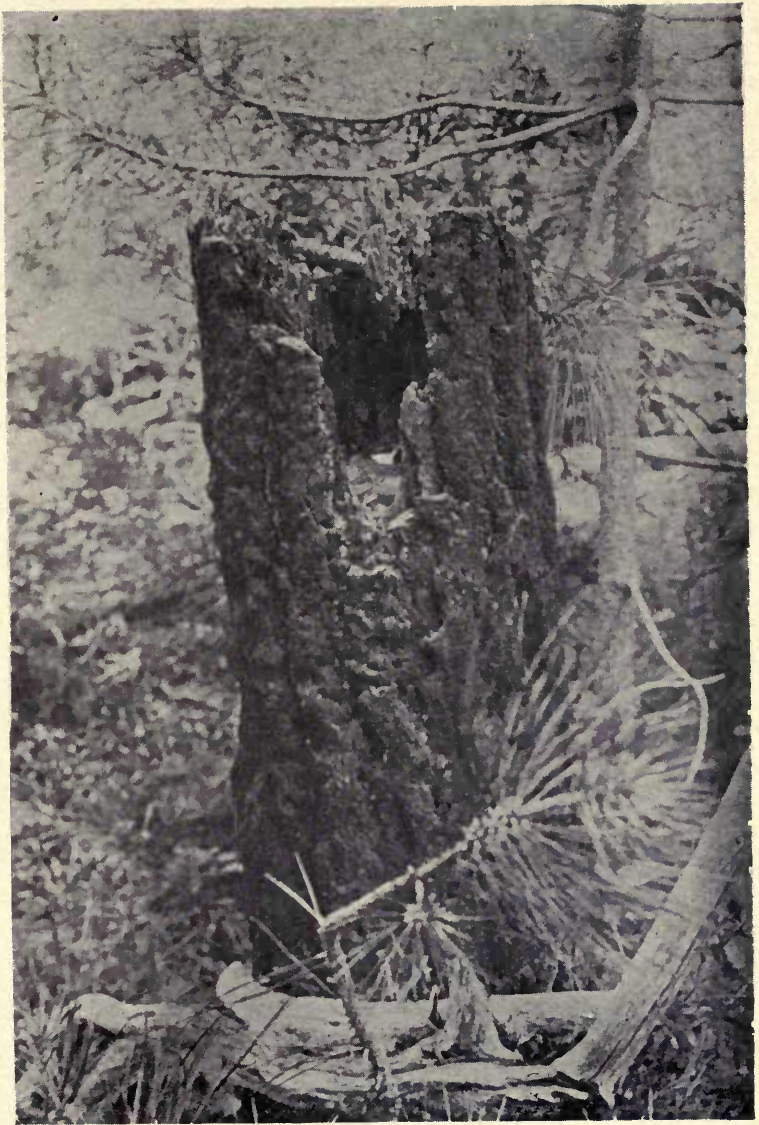

C. Barlow, Phot.

Chicadee's Nest in the Top of a Hollow Stump 



\section{The Seamy Side of Bird-Life \&}

blue jay's nest lately subject to a similar accident. A dove's nest that I had been watching, because of its unusual position on the edge of a ledge of rocks, came to an end by the eggs being rolled over the cliff in a gust of a thunderstorm.

The only nest of those among tree branches really safe in respect to gales is the pendent purse of the Baltimore oriole, which sways with the elastic twigs at the extremity of which it hangs, and suffers no harm as long as they hold their form. This nest is secure against many other dangers to which most are exposed, and probably the comparative abundance of this beautiful denizen of our parks and orchards and rural highways is largely due to this fact.

Misfortunes that befall bird families through physical agencies, such as rains, floods, gales, forest fires and the like, play but a small part, however, in the "infant mortality" of the woods, beside the loss from marauders of various sorts, from the bird's-nesting boy or cattle's crushing foot to the minute insect vermin that sometimes compel small species to abandon their 


\section{The Wit of the Wild \\ \&}

hair- or wool-lined nests before the proper time.

Eggs and young birds form a large item upon the bill of fare of many animals in the early half of the year. Hardly any carnivore will refuse to rob a bird's nest, and many diligently search for them. I was passing through a thicket the other day with my terrier at my heels when a field sparrow jumped away from my feet in a manner indicating that she had just left her nest. While I was searching about for it I glanced at my dog and saw the little rascal-who is by no means thievish-with his nose in the poor sparrow's snug home in a low bush, licking up the remains of the last egg.

This momentary return to primitive ways on Waggles's part reminded me that in the Arctic regions the foxes grow fat in spring after their winter famine by feasting upon the eggs and young of the marsh-breeding water-fowl, and nearer home the foxes doubtless help to decimate our nesting game-birds.

The mink, badger, skunk, muskrat and woodrat are all robbers of ground-built nests, and 


\section{The Seamy Side of Bird-Life \&}

even the mice destroy many small ones, while the wildcat, weasel, raccoon and red squirrel, climb trees in a systematic search for eggs and squabs, subsisting largely at this season (when, indeed, other food for them is scarce) upon these delicacies. The chipmunk does some similar damage, but the gray and fox squirrels are innocent of it, else it would prove most mischievous to cultivate them in city parks and village streets.

Yet none of these animals, nor in thickly settled districts all of them together, equal domestic cats in this rapine. Night and day, in the neighborhood of towns not only, but upon farms, they range the woods and fields searching high and low for birds' nests. No single agency - with the possible exception of the English sparrow-has done so much to drive away and diminish our village birds as these useless and dreadful "pets."

I was told by an intelligent man, who took pains to "keep tabs" on Tabby, that one single house-cat in western New York last summer destroyed sixty-eight nests within a radius of 


\section{The Wit of the Wild \\ \&}

a mile from the farm-house. Every lover of birds and all Audubon societies should organize the fiercest kind of a crusade against vagrant cats as the prime movement in every plan for bird preservation.

Several birds are nest robbers, the most arrant offenders in the United States being magpies, crows (especially the Southern fish-crow), jays and, along the seashore, certain gulls. These destroy thousands of sets of eggs in each district every spring. In a special sort of way, and locally, the English sparrows belong in this criminal list, for they often tear nests to pieces in order to rebuild them for themselves or to use the materials. The worst sufferers from these bandits are the barn swallows, which have been greatly lessened in many localities in the East by this means.

The birds of prey are active at this season, too, especially the owls, which pounce at night upon the sitting mothers and, dragging them from their nests, leave the little ones to starve or, perhaps, to form a second course of the meal. 


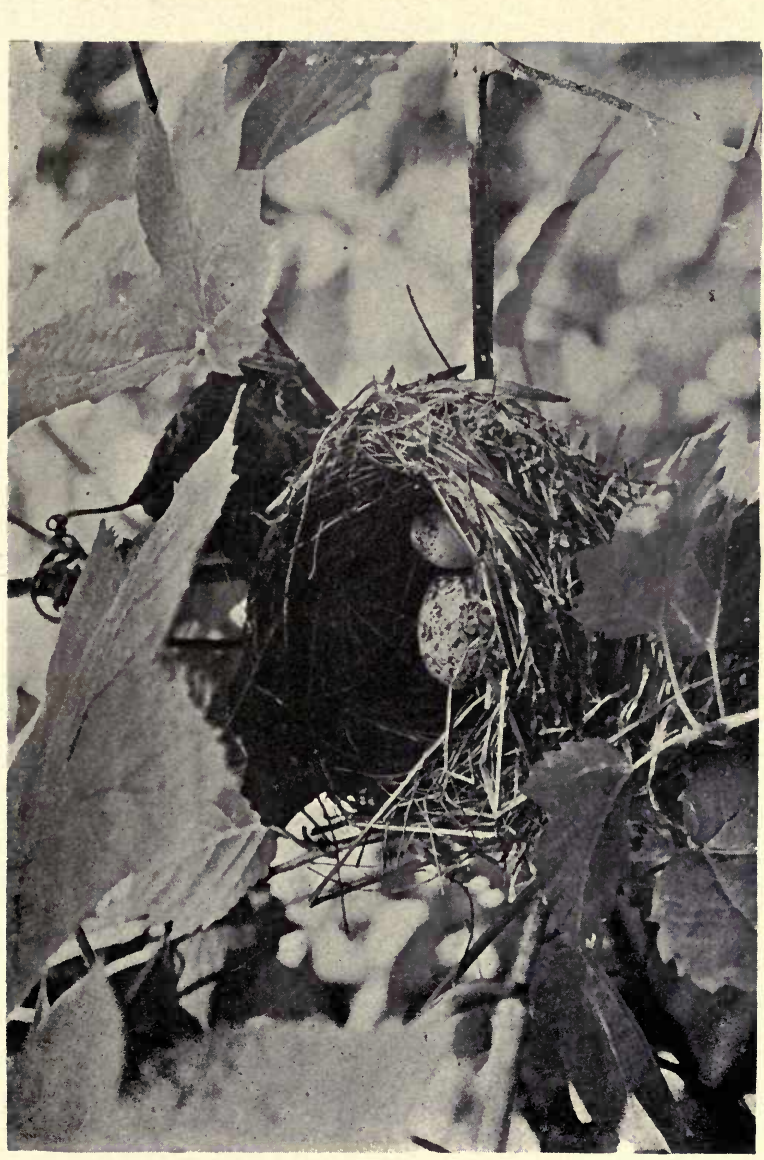

혐

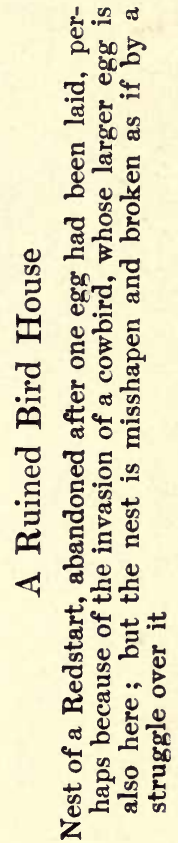





\section{The Seamy Side of Bird-Life}

\section{\&}

Even worse are the snakes. An African serpent feeds so exclusively upon eggs that it has a mouth especially fitted for breaking and consuming them. Birds breeding on the ground are especially liable to this foe, and it is the natural hostility all birds feel toward this enemy that leads them to attack it, of ten with such recklessness that people say the snake "fascinates" them within reach of its stroke.

In our country the most persistent and successful nest-hunter is the blacksnake, which is an expert climber. Every ornithologist can tell of dozens of nests he has known to be despoiled by this sable marauder; yet it often fails. I saw one knocked from a high limb within a yard of our house porch by a couple of robins who came home just in time to protect their property. Blacksnakes will ascend to astonishing heights, explore the tree-tops with great skill in festooning their weight across the slender branches, and search woodpeckers' holes and every cranny for a variety of prey. It is this serpent, instead of the rattlesnake, which never climbs trees, that Audubon should have repre- 


\section{The Wit of the Wild \\ \&े}

sented in his spirited but erroneous picture of the brown thrashers defending their home in a bush.

When all these dangers are thus passed in review, one begins to understand how perilous an experience is a bird's attempt at domestic life, and how needful are all possible circumstances and qualities guarding and favoring it. 


\section{Three Tragical Bird-Romances}

\section{\&}

THAVE certain rural friends in the Hudson Valley, in whose society I delight so 1 much that I am accustomed to jot down from time to time memoranda of their doings. Thus after a while I find myself in possession of little stories whose very simplicity of truth constitutes a charm often lacking in elaborate fiction. Such is the record of the midsummer affairs of three familiar birds who gave me their confidence or gained my sympathy.

June 22.-Four days ago the pair of phœbe flycatchers which had been investigating the porch for some days, always together, suddenly began in great haste to settle themselves on one of the timber-ends that support the overhanging roof of the south gable. But which one? There were a dozen there just alike. Poor little Phœbe couldn't select among them, 


\section{The Wit of the Wild}

\section{\&}

and made a beginning on one only to turn discontentedly to the next one, until every timber on one side of the gable was spotted with muddy semicircles. I showed this situation to a literary neighbor, and he immediately wrote a very pretty and moral essay upon it, but he totally neglected to explain by what criterion, philosophical or sentimental, one timber was at last chosen, so that now a nest is really being completed. The literary essays that deal with nature are often most disappointingly deficient, as I have observed, in respect to the very things I most want to know. If I could find out just what the phoebes need or prefer, I should be delighted to furnish them with precisely suitable quarters, for the sake of their society.

One day I noticed that the male no longer appeared, but the female went on doing all the work, as probably she would choose to do in any case, tearing up thread-like moss by the roots, and bringing it, with as much attached mud as possible, to be plastered into a cup-like structure, where the moss continues alive and keeps green and growing. She worked all day, 


\section{Three Tragical Bird-Romances}

\section{\&}

mostly upon and within it, patting with her feet, pulling and pushing with her beak, and molding the form to the eager breast, with every appearance of fond enjoyment, but progress was slow. At last the task was finished, and I was looking forward to the opportunity for convenient and minute study of her method of rearing her young, when she suddenly ceased to flutter about the gable or perch confidingly on the clothes-lines; and I never saw her again.

June 21.-Robins have been making a home for some days past, not far from the busy phobes, in the top of a maple close by the corner of the kitchen porch. 'A branch of an adjacent poplar runs through the maple-crotch in which the nest rested, and hence through the nest itself, which is thus bound to the limbs of two separate trees. This will make trouble the first time the wind blows.

June 22.-I have been keeping an eye for some time on a nest full of young worm-eating 


\section{The Wit of the Wild}

\section{के}

warblers, snugly tucked into a tiny cave of the hillside close to the path. This morning I found that the fledglings were out, one fluttering in a thick little bush as if unable to make its way through the tangle of twigs. Their mother was distracted with care, and leaped upon the leg of my trousers, where she clung sideways and looked up at me with black eyes "popping" with fear. Then she caught sight of my terrier, and her wits returned promptly. He was comprehensible. Springing at him like a fury, she whirled around his head and then dropping before his nose feigned helplessness, and let the surprised, but innocent, dog chase her until they were far away from the young. I never saw a bird do the broken-wing dodge better. Waggles was astounded to see her quick recovery at the proper time, and trotted sheepishly back to me, confessing that he had learned a new wrinkle in woodcraft. The incident took some of the conceit out of me, as well as my dog; for, without thinking about it, I had been regarding this well-known action of birds as directed wholly toward human alarms, whereas, 


\section{Three Tragical Bird-Romances}

\section{\&}

of course, it is a trick to cheat foxes, snakes and similar enemies first of all.

I was obliged to go away for a few days at this time, and during my absence a tremendous thunderstorm deluged the locality, and filled me with anxiety, when I heard of it, for the safety of my little friends. As I expected, the robins' nest by the kitchen had been sawed in two by the swaying of the alien limb. The pair had then chosen a more secure crotch in another tree, where a very poor specimen of a nest, composed mainly of staghorn "moss" and totally lacking in the customary mortar of mud, was already completed and occupied. The female of this pair was an undersized and apparently immature bird, but her mate was one of the reddest, grandest-looking robins ever seen. Here was a fine example of the WallaceDarwin theory of sexual selection; but it seemed as though it ought to have been his fortune to be beguiled by a better mate. Such a pairing would seem to vitiate the required result.

It was probably the inexperience of this $\rightarrow 63$ ro 


\section{The Wit of the Wild \\ \&}

young housewife that had led to the unfortunate choice of the bad site first taken, and to the poor architecture in both attempts at homemaking. But no one has heard any complaints from the magnificent husband, who no doubt sees charms in his young spouse outweighing considerations of comfort. As both the home and the partnership are temporary, it doesn't much matter. Maybe next year he will have better luck. Possibly he doesn't know or deserve anything better,-fine feathers do not always make fine birds, 'tis said.

June 26.-Found a wood-thrush's nest today, close to the house, which had been constructed and occupied with such secrecy that we had never suspected its presence, though it has been inhabited so long that the female is now sitting. It is a beautifully typical leafmade nest, resting on the flat bough of a hemlock, ten feet from the ground.

June 28.-Already the wood-thrush is so tame that I can go close to her without disturbing her, and, doubtless, were she within 


\section{Three Tragical Bird-Romances}

ค

easy reach, I could teach her to let me stroke her back, as I have taught other birds.

Last night I made a tour of various nests at midnight and found all the mothers sitting, of course; but unexpectedly I aroused no males by disturbing these females. Could a small marauder have ravaged without resistance? or did silently watchful cock-birds perceive my friendliness? I regret to say I think the former was the case. They were sound asleep somewhere else.

July 1. - The male of my interesting pair of robins spends most of his time in the dead top of a large tree, about one hundred feet in an air-line from his home. In this old birch, which is a house of call for the winged people of the whole neighborhood, Cock Robin has a particular perch whence he can see his nest; and near him, on the outermost tip of an extended dry twig, sits most of the time a hummingbird, no doubt in view of his family treasures somewhere on the wooded Rimrocks hillside. 


\section{The Wit of the Wild \\ \&}

To-day there suddenly dashed into the tree, with a loud, rasping shout, a bully of a bluejay. The hummer glanced into the air and vanished like the bursting of an iridescent bubble; but the robin whirled and drove at the stranger without an instant's waiting. Like a flash his little mate came from the nest to her husband's aid, and a third robin rushed in from elsewhere, so that in two seconds the braggart jay was routed and fleeing to the woods. What a row it raised! The robins chased him hotly, the wood-thrush sprang from her cradle in the hemlock to give her help, and I could hear little birds joining in the hue and cry as the rout ran up the hillside, till the jay had been driven to a safe distance.

Now and then the robin visits his wife at the nest, and, I think, takes her a cherry; but I get no sight of any conjugal attentions on the part of the wood-thrush, in whose nest are only three eggs. Probably it is a second brood.

July 3.-Both robins have disappeared, yet no one has seen any harm befall them nor heard 


\section{Three Tragical Bird-Romances}

\section{\&}

the outcry that would surely follow an attack. There are no bird's-nesting boys in this locality, and few, if any, house-cats. I climbed to the deserted nest this evening, and could see no signs of a struggle, nor were there any eggs or remnants of any; yet the bird had been sitting several days. Did she find herself unable to produce eggs, and therefore abandoned the nest? It is a mysterious outcome of a queer little bird-romance.

July 5.-Father Wood-thrush never stays close to his nest, and is rarely seen; but while his mate is brooding, her golden mouth often gasping for air during these hot, stagnant days, he sits in a tree not far away and sings almost continuously, and evidently to her alone. It is not a loud, rollicking song, such as he still sometimes gives in the cool of the morning, but a low, fond and exceedingly melodious chanta perfect lullaby, altogether outside of the public repertoire of this virtuoso of the woods. It is in four parts, the intervals five pulse-beats in length. 
July 14.-The wood-thrush, presumably, is rejoicing in success; at any rate three young ones are squirming about in the bottom of the nest this morning. A friend wishes to photograph them, so this afternoon we parted the twigs in front of the nest and clipped off some of them to expose it to view more clearly, the familiar bird paying very little attention to our tinkering.

July 15. - Last night fell dark, and at midnight a storm of wind and rain beat upon us for three or four hours. The photographer came over about nine o'clock, but when we went to the thrush's nest it was empty. No commotion had been heard, such as an owl or blacksnake would arouse; and there were no marks of violence about the nest indicating that it had been harmed by the tempest or by a marauder. Yet the home was desolate. I knew of a precisely similar and unexplained disaster overtaking the brood of a vireo last year.

These ever-recurring tragedies lend a tinge of awe and sadness to all nature-study. After 


\section{Three Tragical Bird-Romances}

คे

careful consideration I have concluded that only one nestful of birds out of seven, on the average, is saved to reach maturity. Greater than protection for adult birds is the necessity of guarding the cradles of their young. 


\section{A Tiny Man-o'-War}

ฉ

MONG the tiny ocean tramps that drift along the Gulf Stream into our northern harbors during September days, when the water gets warm and the weather is calm, none is more strange and lovely than the Portuguese man-o'-war. It is an iridescent bubble, courtesying to the ripples as the tide bears it along, while flashes of prismatic color sweep over its surface with every movement of the azure mirror upon which it dances so gayly.

Under the smiling skies that arch Antillean seas you may behold fleets of them like convoys of tiny toy boats painted in rainbow hues, and after great storms they are sometimes thrown by tens of thousands on the coral beaches in piles and windrows that seem globules of delicately tinted glass or huge, irregular pearls, gleaming in purple and green, carmine and gold. 


\section{A Tiny Man-o'-War \\ \&}

Now, this exquisite gem of the ocean-apparently a creature of foam and sunlight, a flower blushing in the desert of the mighty deep-is not orly a living and possibly sentient animal, but a most curious and complicated community or family: a ship and crew in one, needing no commander, working always in harmony, voyaging ever, and, like a privateer, protecting its radiant structure and gathering supplies as it goes. Nobody knows who gave it the name "man-o'-war," nor whether he understood the truth, but it was a happy thought. In classification it ranks as a free-swimming compound hydrozoan of the order Siphonophora, - a group intermediate between jelly-fishes and polyps. The genus is Physalia, and our wanderer Physalia pelagica. It consists of a unison of four parts, or kinds of parts, which some naturalists regard as separate classes of united individuals (or "persons"), and others as the organs or appendages of a single animal. The reasons why the latter seems the better view are too technical for statement here, but a plain account may be given which 


\section{The Wit of the Wild}

\section{\&}

will enable anyone to understand the creature who will lift a physalia from the waves in a bucket and then gently pour it into a glass jar or aquarium of sea water, and so preserve the delicate animal alive, to be examined at leisure. It will not bear touching.

It will then be observed that the gaudy float - sometimes eight inches long and three high is a pear-shaped bladder-like thing, tensely inflated. It is pinched along its top into a brilliant crest, and from its lower side, mainly toward the larger (front) end, depend a great number of filmy appendages.

This float is in reality a sac filled with air, which enters it through an opening in the pointed end. The sac, although seeming as thin, and in parts as diaphanous, as a bubble, has a double wall-that is, it is one sac inside of another; and it abounds in muscular fibers, by which the animal can vary its shape, contracting the sac at will into creases and opening or closing the air door; and the beautiful creature, when young, is able by this means, when rain falls or the winds blow cold, to expel 


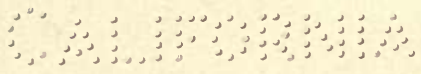

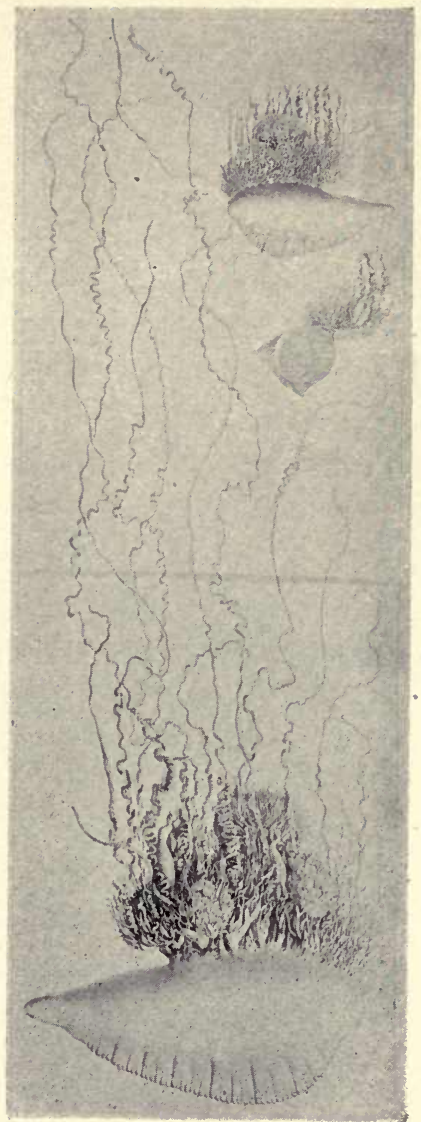

\section{Portugese Man-'o-War}





\section{A Tiny Man-o'-War \\ \&}

the air from its float and sink below the surface to warm and quiet levels until better weather recalls it to bask in the sunlight and sail upon serener seas. Thus this man-o'-war may be called the submarine boat of nature's miniature navy - a primitive model for our Hollands and Maxims. But with age comes stiffness; and the older ones must drift at the surface and take the storm as well as the sunshine, while the youngsters "go below" to disport themselves at ease.

It is a lover of warmth, and those seen along northern coasts are venturesome vagrants who have wandered up the Gulf Stream and then been blown astray. They are occasionally seen in New York Bay, but are more common from Long Island to Newport.

Innumerable pigment cells give a permanent color to much of the sac, rich blues changing in places to rosy tints; but, besides this, the surface is striated or scratched with exceedingly fine straight lines, crossing each other at right angles, forming prisms-thousands to the inch -which break up the light and cause it to play

\section{or 73}




\section{The Wit of the Wild \\ \&}

over the surface with that same shifting iridescence which illumines so beautifully the nacreous lining of shells (mother-of-pearl) and the surface of ancient glass.

Seen under a microscope, this striated coat glistens with a magnificent display of silvery light. Furthermore, the pointed end (which is the overhanging stern of this fairy boat) may be lifted, or depressed, or turned a little to one side, so that it acts partly like a rudder and partly like an after-sail, apparently enabling the mariner to steer a course, even somewhat up into the wind. I say " apparently," because in truth the "steering," no doubt, is a mechanical result of the pressure of the breeze together with the dragging back of the flat trailing tentacles, sometimes fifty feet long when fully stretched out, which tips up the stern and, in a strong wind, "brings the ship to," head on to the gale. Mariners, when hard pressed by a gale, sometimes rig and trail astern a "drag" for precisely the same purpose.

This float that we have been considering is a single organ whose sole service it is to carry the 


\section{A Tiny Man-o'-War \\ \&}

rest about, and it is the first part of the animal to develop at birth. This birth may be from an egg-an almost invisible globule voided into the sea to take its chances of escape from a thousand perils long enough to develop into a tiny sac and gradually to perfect its system of appendages. More often, probably, the young physalia begins as a bud attached to one of the reproductive appendages of its mother and does not break off to start on an independent existence until it is pretty well advanced in growth. This is so jelly-fish-like that some naturalists say the float is a true medusa. I have italicized the word "probably" in the sentence above, not to throw doubt on the statement, but to emphasize the fact that no female physalia has been observed: all the specimens we see, apparently, are males.

As it becomes larger there gradually grow from the lower surface of its outer wall four pairs or groups of appendages or associated organs which have been named zooids, or polypites. These vary in form and in function, for in this society there is complete division 


\section{The Wit of the Wild}

\&

of labor-fixed individualization, which is never transgressed because each member is capable of but a single kind of work.

Three kinds of zooids may be discerned. The first to attract the eye are the long and writhing tentacles which trail like living thick-edged ribbons beneath the float. Some are contracted into tight brown ringlets, others crinkled, others hanging loose and long. Their elasticity is enormous, so that when the wind is strong they may trail thirty or fifty feet behind a physalia of large size, forming what sailors know as a "wind anchor" against drifting ashore and causing the little ship to " heave to," as has been explained. The business of these scores of long, sensitive, contractile tentacles is to find and seize the prey upon which this man-o'-war subsists. This food consists of small, juicy larvæ of shellfish of every kind, fragile oceanic relatives of the shrimp; tiny fishes, and anything else small and soft.

The instant such an unfortunate swims against the invisible nets of this Medusa of the sea, the tentacles cling and wind about it, and 


\section{A Tiny, Man-o'-War \\ \&}

from them burst hundreds of exquisitely sharp, thread-like and barbed darts (until then hidden in pockets opened by a touch), which penetrate the victim's flesh and carry into it a fiery poison (perhaps formic acid) that benumbs the nerves and paralyzes effort.

Then the tentacles begin to contract, and slowly draw the captive up into the living thicket beneath the float, where it comes into contact with shorter and broader tentacles bearing flask-shaped bodies, whose pores are filled with the equivalent of gastric juice. I have seen a physalia kill and lift to its "mouths" a fish longer than its own float.

These feeding organs gradually absorb and digest the nutritive part of the prey and send it circulating, in the place of blood, throughout the space between the walls of the float and up and down the interior of every pendent organ, and so the whole is nourished impartially. There are large and small feeders, each with highly colored tentacles of its own, and some of them, according to Prof. 'Alexander Agassiz, seem also to perform a respiratory function. 


\section{The Wit of the Wild \\ \&}

The stinging cells which serve to render helpless its prey are also the defense of the physalia. They are the batteries of guns of this Portuguese man-o'-war, and cause it to be avoided by many fishes and other animals that might otherwise like to eat it. If you should put your hand into this tangle you would quickly withdraw it, red and smarting almost as if you had thrust it into flame.

Big things like whales and turtles gulp down the physalias, but even the green turtle, which is fond of them, is often rendered almost blind by the stings inflicted upon its lidless eyes; and Professor Mayer says that the loggerhead invariably shuts its eyes when it seizes one. Nevertheless, extraordinary as it may appear, certain small fishes habitually hide themselves beneath this fiery veil from their worse enemies without; they go and come after their own food, accompany the physalia as it travels, and live amid its tentacles as a refuge. Yet, for many of them, it is only a leaping from the ashes into the fire, for every now and then their protector seizes and consumes one of the panic-stricken 


\section{A Tiny Man-o'-War \\ \&}

flock, whether as payment for "protection" or pour encourager les autres you may decide for yourself.

A third sort of zooid, hanging like the others in bunches attached to the float by a single central stem, comprises those whose function is reproductive. These are shaped like Indian clubs and have purple walls and a creamy interior. Like all the other appendages, they are in continual motion, waving about, writhing, contracting and dilating with the eternal restlessness of the sea itself, and ever the rainbow lights shift and glide beneath the silvery sheen.

Such is the structure and history of this elegant creature, which seems as fragile as if blown of thin glass and draped with gossamer, yet survives the beating of gales and the turmoil of the billows. It has many exquisite filmy relatives in the warmer seas, some of which are frequently met with even on the coasts of New England.

Buzzard's and Narragansett bays, indeed, having a southern opening, receive numbers of these and other tropical visitors every season. 


\section{The Wit of the Wild}

\&

All are less conspicuous than the physalia, because more transparent and colorless, but they are more fairy-like in delicacy. Instead of a big crested float they have one or more small floats, made buoyant in some cases by a filling of an oily substance. An exquisite example is Nanomia. Another is Vellela, which lifts from its purplish, raft-like disk a triangular sail by which to trim its course to the breeze.

Of the latter, also a siphonophore, Prof. A. G. Mayer gives the following description in his valuable "Seashore Life":

"Vellela mutica is an exquisite creature rarely seen along our [northern] coasts, but it occurs in great swarms in the tropical Atlantic. The body is an oblong disk about four inches long, and deep blue-green in color. The upper side of the disk is occupied by the chambered, gasfilled float, which is chitinous and gives rise to a sail-like crest. On the under side of the disk we find a large central feeding-mouth surrounded on all sides by numerous little mouths and reproductive polypites. Near the outer edge of the under side of the disk there is a $\rightarrow 80$ so 


\section{'A Tiny Man-o'-War \\ ६}

row of long blue tentacles. Large numbers of little jelly-fishes are constantly budding off from the sides of the reproductive polypites and swimming away in the water; but their further development is unknown.

"Porpita linnæana is related to Vellela, but is smaller, being only about one inch in diameter; also the disk is flat and circular, and there is no sail-like ridge to the float. When seen in the water it appears as a deep blue circle, while the chambered float at the center glistens with a beautiful greenish iridescence. Underneath we find feeding polypites and tentacles very much as in Vellela. Porpita is rare along our coast, but between Cuba and South Carolina it is sometimes so abundant as to fleck the ocean for miles with specks of brilliant blue."

None of these wanderers, probably, ever survives our winter, and few, if any, escape it by returning to the Gulf Stream, against whose current they could make little headway if they trieds. 


\section{My Snake-Stick}

\&

T $\mathrm{T}$ was not a wooden toy made in imitation of a serpent, like one of those unpleasant

1 Japanese things; nor a cane with a handle carved like a snake's head; nor a cobra-hiding bamboo-tube, such as Hindoo assassins use, but simply a-but wait a bit.

Helen came into the house one day from the other side of the creek, looking much disturbed.

"I have seen a copperhead," she stated, as she set down her berry basket.

"Nonsense! There are no copperheads here; and you wouldn't know one if you saw it, anyhow," said I.

"Wouldn't I? Perhaps I didn't learn anything about a copperhead in New Jersey the other day!"

I could not gainsay this remark. She had been with a botanical party in the suburbs of of 82 bo 


\section{My Snake-Stick \\ \&}

Newark, and in poking about a brushy pasture had observed a large snake glide out of one side of a tuft of huckleberry bushes as she placed her foot into the other. Both halted and looked at one another, the sunlight glancing off the girl's chestnut hair, but reflecting no such reddish intensity as from the flat and burnished head the snake held erect, while it calmly awaited her next movement.

"A copperhead!" she called out, and half a dozen young men rushed gallantly forward and crushed the creature; a copperhead seldom runs.

The professor told the class that she was right. He pried open the mouth, showed them the poison fangs hanging like curved thorns from the upper jaws, and explained that it was a true pit-viper-a rattlesnake, except that it had no rattles, but only a horny tip to the tail; a peculiarity that allied it with the moccasins of Southern swamps-the two forming the genus Ancistrodon.

Helen remembered this field-lesson very well; and when she added that the snake she had just 


\section{The Wit of the Wild \\ \&}

seen was long enough to reach from rut to rut of the wood road across which it lay, I was bound to believe her identification.

"What did you do?" I asked.

"Do? I stiffened with fright, and just looked at him as he lifted his head six or eight inches from the ground and dared me to disturb him. I turned back and crept home a quarter of a mile around."

"Why didn't you kill him?"

"I had nothing to do it with, and he looked so fierce I thought he'd leap at me if I stayed there an instant longer."

"But those snakes never attack anybody out of their reach," I said.

"So they say. But I didn't care to take the chances. A garter-snake rushed at me the other day, and why shouldn't a copperhead?"

"Oh, the little, harmless serpents have to bluff like sixty to make up for their real weakness; but the poisonous ones know their power and don't bluster. Next time you must take a good, long stick with you. I'll get you one now." 


\section{My Snake-Stick \\ \&}

A straight young pig-nut was selected forthwith, cut down, and trimmed.

It was a beautiful wand-straight and some eight feet long-much farther than any snake could strike, for the animal never jumps, as popularly understood, but only darts forth its head perhaps half the length of the body, and it was tough and lithe, so that its pliant tip would lie flat along the ground like a flailan ideal snake-stick.

'A serpent's backbone is extremely brittle. A light, sharp blow will almost invariably break it, fatally injure the spinal cord and render the animal helpless, and a second blow on the head finish it. Yet so sluggish is the nervous life and so intense the muscular energy that the creature will often seem to remain alive-especially toward its tail-for a considerable time. This is partly reflex energy, and partly nothing more than the mechanical action resulting from unequal changes in the tension of the muscles following death. These muscles are small and extremely numerous, controlling each of the many ribs; and as they stiffen and loosen irregu- 


\section{The Wit of the Wild \\ \&}

larly they move the slender hinder end of the body with an appearance of life; and so the country boys will tell you that no snake will die until sundown.

I was returning home along the same woodland road the next day, when my eye caught a peculiar quiver and became aware of a narrow, tapering object as large as a lead pencil, and of the richest burnt sienna red color, right beside my foot. I wasn't jumping to make a recordso it is not worth while to state precisely how much ground was cleared in the bound that followed, but it was considerable. Then I looked back. There lay the tail slowly vibrating from side to side like that of an angry cat; and beyond it could be distinguished a sinuous body, dull reddish-yellow, very thick in the middle, and tapering toward each end, with angular dusky blotches forming a zigzag pattern along its sides. Unquestionably this was a "pilot," as people here in the Hudson Valley call the copperhead.

It is said to be the peculiar distinction of this snake that it will turn and bite you as you 


\section{My. Snake-Stick \\ ६}

pass without any preliminary movement or warning. But this specimen did nothing of the sort, nor did he even draw himself into a coil, but simply lay still, with upraised head and attentive eye, in which I thought I saw a cynical glare, as if the creature might be saying to himself: "Well, if I was a great animal like that I wouldn't jump at the sight of as small a thing as I am."

The path was one we continually used; often after dark. That this reptile must be put out of the way was certain, but how?

The reader may deem this much ado about nothing; but there is to me, as to most persons, I believe, a peculiar terror in approaching a poisonous snake, an unexplained, yet real repugnance felt for all reptiles, originating, no doubt, in the frequent inability to distinguish at a glance between venomous and non-venomous kinds, and strengthened by heredity.

This feeling must have arisen in a primitive time when our forefathers dwelt in the junglea tropical jungle, one must believe-where many serpents were dangerous, so that it behooved 


\section{The Wit of the Wild}

\section{\&}

every one to halt and scan a snake carefully the instant it was seen (and that is not, you may be sure, until after it has seen you) to make sure it was not a cobra or something of the sort. Such a habit and dread impressed upon children as their first lesson in the cautions of woodcraft, would become ingrained into the very brain of the race as an almost instinctive fear. By no amount of knowledge or philosophy can I rid myself of this gruesome inheritance. I have known good naturalists who have said the same thing, and confessed that it made a serious drawback to the pleasure of their rambles.

Others, on the contrary, handle the bad ones, cautiously, but calmly, and play with the harmless ones with no more repugnance than if they were fishes or salamanders or frogs, - cold and reptilian things, by the way, that it does not disturb me to handle. It is a curious coincidence that most of these fearless persons are in terror of spiders!

To be reasonably "afraid of snakes" is the safer state of mind, however, in the eastern part of this country, where every rocky hill west of 


\section{My Snake-Stick \\ \&}

the Connecticut River is likely to harbor rattlesnakes, or copperheads, or both. The rugged hills along the Hudson abound in them; and they occasionally come into our paths and little clearings in the woods on the rough hillside and would lie basking in the sun; that is, we or others frequently saw them, and usually were able to kill them, for they seemed indifferent about moving, though they can run swiftly when they please. Their hunting and wandering about is done mainly at night, as with most terrestrial animals.

One day a party of young ladies from Vassar College came across the river for a day's ramble in the woods, and encountered a handsome snake, about eighteen inches long, lying stretched right at our steps (no one was at home that day) as if it owned the place. They gathered about it and one of the girls stooped down and began to stroke it, first with a little stick and then with her bare hand. But when my neighbor came along, and, keeping his wits about him, had discreetly got the fair enthusiast out of harm's way, he set off a "Vassar 


\section{The Wit of the Wild \\ \&}

yell," as if he had touched an electric button, by the remark: "That's a half-grown copperhead!"

Another time I saw a lady stumble over a small copperhead, and positively disentangle it from her dancing feet without being bitten. Probably this snake was as much disconcerted as the other had been soothed.

These incidents illustrate what you can do with even a rattlesnake-sometimes; but it is a mighty unsafe experiment to indulge. You can make no bargain with a viper! Which brings me back to my snake in the grass-the first I had ever encountered.

Certainly this copperhead must be dispatched -but how?

I could see no club anywhere near. I had in my pocket a new knife which had lately been given to me-with a lovely desire to please, but very poor judgment in cutlery. The first time I had used it the blade had turned up as if it were tin. Nevertheless, with it I gradually hacked off a stout oak sapling-a very fair snake-stick. 


\section{My Snake-Stick \\ \&}

The reptile quietly watched my actions until he saw that I had a weapon and was going for him, when he started off. I darted forward and a couple of vigorous whacks broke his back; and, turning him over until the ugly black spots on his yellow belly were uppermost, I tossed him far into the bushes, and gave thanks that he was out of the way of the children who played up and down the lane; and of the little white dog, who, however, was afterward bitten on the toe and nearly died.

A few days later the ladies of our camp were going along that same woodland road to town one morning, when they suddenly came upon two large copperheads stretched out in the middle of the track. Their startled halt and nervous grip of snake-sticks-none of them ventured out now without snake-sticks-accompanied by the thought that there was a battle to be fought, were followed by the discovery that both were dead-killed by some other rambler, as the broken boughs and stones lying about testified. Of course it had never occurred to him to get rid of the bodies as a matter of 


\section{The Wit of the Wild \\ \&}

good taste, or because they might possibly shock nervous people. The average rustic is not built in that considerate way. We learnt afterward that a man had encountered these reptiles here as he came along in the early morning. One was coiled up, he related, and the other was circling about it. They paid no attention to him, and after watching them a while he destroyed them.

It is probable that these two snakes were females, about to give birth to their young. The progeny, usually no more than five to seven in number, are not produced from eggs, as in the case of most harmless snakes, but, some time in September, are born alive and very much alive, for they exhibit after a few hours all the activity and animosity of their parents, coiling and striking at anything which threatens them, with complete knowledge of how to use their fangs. When hard pressed, however, they will retreat for safety into the mouth of the mother, to reappear when the coast is clear.

After that experience none of us, men or 


\section{My Snake-Stick \\ \&}

women, went anywhere in the woods without carrying a snake-stick.

This copperhead, or red adder, is reputed to be a lover of dry lands. In the northern part of his range, which reaches eastward to the Connecticut River and northward to the Catskills and follows the Appalachian ridges southwestward, his proper home is on the wild mountains, where he makes a den among the rocks.

Whether it was really a " headquarters," inhabited by a regular colony of copperheads, as has been known to be the habit of rattlesnakes, or whether it was just a gathering for hibernation in company, as is the custom of many kinds of snakes, I do not know; but something very like a den was discovered a few years after.

We had lived on the hillside half a dozen years and had seen and heard of a few serpents near us every year. Meanwhile two or three other houses had been built in the woods on the ridge, and some peat-bogs had been drained and turned into market-gardens near us. All these occupations had been accompanied by the death of a 


\section{The Wit of the Wild \\ \&}

good many copperheads, and we began to think we were really getting rid of them when some workmen on a neighbor's house suspected their presence at a certain spot among the ledges and fallen rocks, and were told to spend an hour of their time daily in hunting them out. This was toward the first of April, when the afternoon warmed the sheltered stones considerably, and enticed them to the surface. They were found one by one in crevices under leaves, beneath loose rocks, and sometimes out in the sunshine drowsy and inactive, so that it was an easy matter to kill them, and forty-four of various sizes were destroyed before the place seemed empty. This was within a hundred yards of the famous summer-cottage "Slabsides" of Mr. John Burroughs; and his path to our spring, as well as my road in and out to the highway, lay right along the base of these danger-haunted rocks!

But the people who dwell in the rough country between the Hudson and the Blue Ridge have been alongside of this danger all their life, and lose no sleep over it, which shows not only 


$$
\begin{aligned}
& \text {; ; ; ; ; ; ; ; ; ; ; ; ; }
\end{aligned}
$$

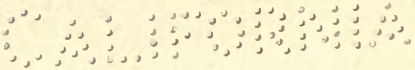

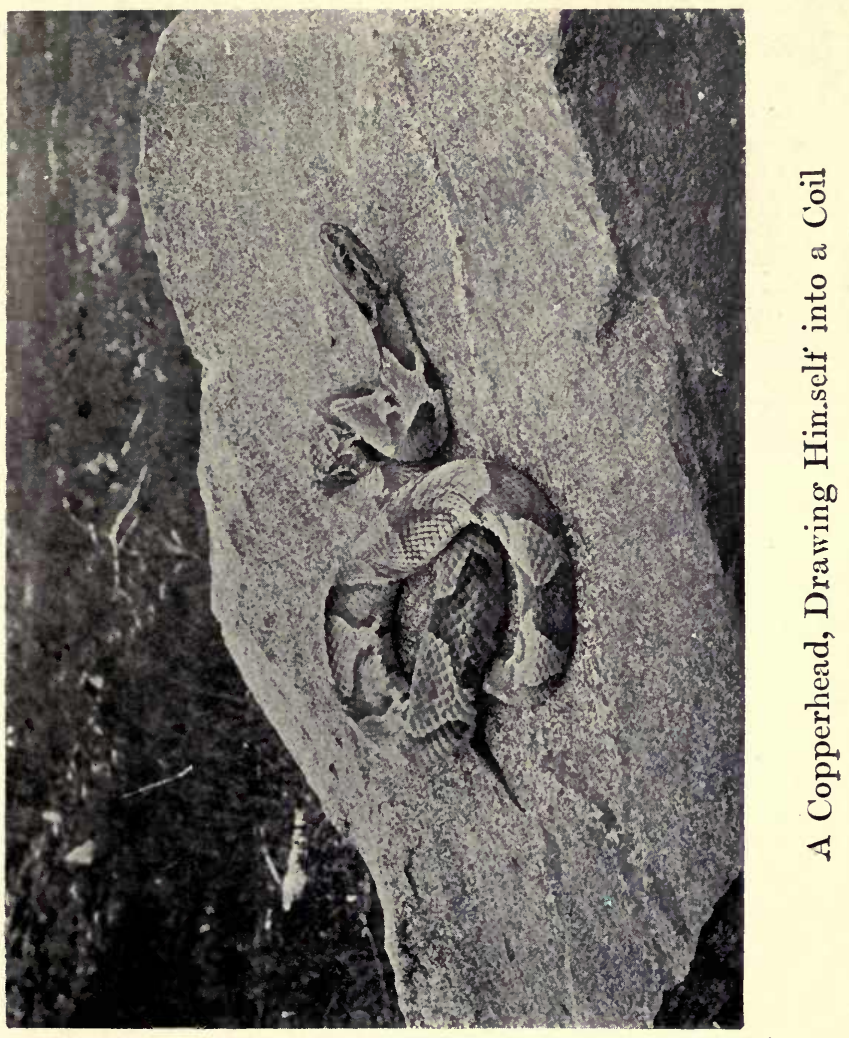





\section{My Snake-Stick \\ ६}

that men grow accustomed to peril, but that in this case the peril is not really great, for it is evident that, at least in the daytime, the snake is not at all aggressive, though able and willing to fight when attacked or provoked; and that reminds me of the experience of Mrs. Tom Murphy, who lived in a log-cabin in the woods about a mile up Black Creek.

"Wan day," as she told Helen, "I stepped out o' my doore and there on top of a rock ferninst the well lay a pilot all curled up, and the childers all playing close by without a wan of 'em noticin' the baste. I let a yell out o' me, and I picked up the first thing handy, a shovel, 'n whacked the shnake over the head, 'n he sthruck me hand, an' I knew thin I was gone. I threw the baste into the brush, and then called the childers ' $n$ run into the cabin. I was wantin' to die as daycent as maybe, and I wint and lay down on the bed, biddin' the childers all good-by and lavin' word with 'em for the ould man at his wurrk in the ice-house. Thin I sint 'em all out again so they shouldn't see me in me agonies. 


\section{The Wit of the Wild \\ \&}

"I lay there all straight out, as if I was a corpse at a foine wake, wid me hands folded proper, awaitin' to die, and wanst in a while the young wans' $d$ come in and say: 'Are ye dead yit, mamma?' 'nd I'd say: 'Not yit.' Andwad ye believe it?-I lay there more'n two hours, composin' meself and praying to the Virgin, and I niver died wanst! Then I said to meself : 'It's an ould fool you are, Mrs. Murphy,' and I got up."

But all this information as to the manners and customs of this lurking danger of the northern woods was gained long after the occurrence which I started out to tell much more brieflynamely, how we verified Helen's assertion that she knew a copperhead when she saw it; and, secondarily, how we lost faith in a theory. The theory was that this is a dry-land snake exclusively. Compared with its cousin, the black water moccasin, it is; and down South they distinguish it as the upland moccasin, and look out for it in the cottonfields where it hunts for mice. But in our region we learned that the tribe regularly migrates from the stony 


\section{My Snake-Stick \\ \&}

hills, where it spends the winter, to the swamps and river-courses and meadows, where it passes the summer and finds its food abundant; and May and October are the months when it makes its migratory journeys and is most of ten seen -or felt. But at that time, relying upon the books, we felt safe along the creek, where various water-loving snakes, as the racers, were not uncommon.

One afternoon we were all down at this stream, where we had an old skiff, so leaky that Helen said she always felt like a criminal when she was using it-out on bail.

The creek was obstructed just below the landing by a fallen tree. Its broad disk of upturned roots was reared in the air near our bank, while its trunk extended clear across the stream. If it could be broken our boat might float a long distance beyond it.

So one day Helen paddled me out to it in: the boat, and I pulled off shoes and stockings, and scrambled out upon the old log to examine into the matter. I was walking upward along the trunk toward the roots, when at a cry I 


\section{The Wit of the Wild \\ \&}

glanced back to see the girl pointing in terror to where, just ahead, a great copperhead lay festooned in rich golden undulations along the topmost rim of the pile of roots. The eyesthat are really red, but looked black above the cream-white lips that hid his fangs but displayed the forked flame of his tongue-were fixed upon me, and slow, wave-like wrinklings crept along his thick, burnished, heavily scaled sides, which were flattened and met in a ridge upon the spine like a slated roof.

I stared back at him. Barefooted, weaponless and balancing myself upon that smooth bridge, I had no means of fighting, yet was resolved not to let the venomous thing escape.

As I gazed the serpent, with no winding motion whatever such as we use in coiling a rope, but slowly, by the contraction of every part at once, drew himself into a heap, part coil, part folds; and there he lay-a gorgeous pyramid of coppery gold upon the very summit of the earth-clogged roots, his head elevated, his armor reflecting the sunlight, and his daggers drawn. 


\section{My Snake-Stick \\ \&}

"And to think," exclaimed the girl, under her breath, "that yesterday I went wading close by that stump, to get that cast-skin I took home - perhaps the old coat of this very snake!and came within an inch of clambering up among those very roots! And, look! I can see the hole where he lives."

Finding that this bravo of our jungle, accustomed to fear nothing the woods or water contained (excepting only the all-conquering blacksnakes), meant to stay upon his throne, unalarmed by our presence, I asked a little boy standing on the river-bank to fetch my revolver from the camp. Then I went back into the boat, put on my footgear and we went ashore.

Taking the pistol in one hand and Helen's well-tried snake-stick in the other, I crept through the bushes to a position in the rear of the old stump. The snake scrutinized the movements with vigilant eyes, arched his neck with increased ferocity, yet changed position only far enough to face me well when I menaced him from the new direction. 


\section{The Wit of the Wild}

\section{\&}

He was now above me and had so much the advantage, if he dared to throw himself down, that I confess to some timidity about going too near, and therefore opened fire at the distance of a dozen feet.

None but a long practiced hand can attain to accuracy with a "bulldog" pistol, short and heavy, and the first ball passed through the shell of earth beneath the living target, causing it to shrink down into a much smaller mark. The next bullet sang close beside his head, now stretched out with rigid, slender neck-though even to the last moment his mouth was never opened, as the pictures invariably represent it to be in such contests as this.

The third bullet plowed a furrow across his back and filled the animal with rage. Swinging around like a flash of yellow light he thrust his head straight toward me with vicious energy, until more than half his body was extended beyond any support, and for an instant I thought he meant to dart through the air like a living lance. Dropping the revolver, I dashed forward and with one blow of the snake-stick broke 


\section{My Snake-Stick \\ \&}

his knotted neck, and the writhing, deadly coil of red and gold stretched out, dropped like a spent rocket into the water and slid away down the rapids. 


\section{Animals that Advertise}

\section{\&}

$\prod^{\text {HE }}$ literal meaning of the expression to advertise is "to turn toward," and we have stuck to it much more closely than to most words derived from a foreign language. Every man who issues an advertisement tries to turn your attention, if not your person and pocket, to him and his wares. Now, in this sense, a great many animals are truly advertisers, following primitive methods.

The first form of advertising was the one still followed in barbarous countries and in some of our rustic communities-that of crying out one's occupation, or wares, or whatever announcement is to be made. The voice of such criers, alas! is still to be heard in the land, and strangers usually need to be told what the man is saying; but the crier's voice and the cadence of the shout quickly become familiar to his customary hearers. They are just putting an end 


\section{Animals that Advertise}

\&

to one of the relics of this practice in London by stopping the cry of the chimney-sweeps, which is only a long wail, the original words of which were long ago lost and forgotten; and this very year I heard them in the old town of Stirling, in Scotland, telling the people when certain excursion trains left on the railway.

Another very early form of advertising, not yet quite extinct, was the display of some symbol of the business done, like the mortar and pestle of the druggist, the uplifted hammer of the goldsmith, or a more conventional symbol, such as a green bough, to indicate a wine-shopwhence the proverb "Good wine needs no bush." Now, one or the other, or both, of these methods are used by animals to make announcements which they desire to publish.

These announcements mainly-perhaps altogether-fall under the heads of information to the evilly disposed or careless to "keep off," warning to friends of danger; challenge to the prize ring; and desire for a mate. The marriage advertisement, indeed, is one of the oldest and most ubiquitous institutions in nature, in- 


\section{The Wit of the Wild}

\section{\&}

stead of a modern notion, the product of newspaper enterprise, as most of us consider it.

You see that I am leaving aside here the varied utterances, tones and inflections by which the higher animals really converse with one another. That is speech, not advertising. And I wish to add another prefatory word, though perhaps it is needless-namely, that of course we must not suppose that the animals think of these announcements in our sense of the word " advertisement," but are moved by various impulses, some instinctive, some physical, some accidental, even though they may desire to obtain the effect they more usually succeed in getting than do human advertisers.

Take the case of the rattlesnake. When he shakes his castanets above the horrid coil where deadly fangs await his enemy, he says as plainly as the motto on Paul Jones's flag, " Don't tread on me!" All and sundry hear and heed.

He keeps quiet enough when not aroused by fear. I remember camping once in a villainous sage-brush desert in southern Idaho. I had taken off my boots, put on a pair of moccasins, 


\section{Animals that Advertise}

\&

and started toward a near-by stream for a pail of water, when I almost stepped on a rattler, which my light footfall had not awakened. I sprang away and in an instant his rattle was going, faster and faster, singing higher and higher, as he saw me preparing to attack him. He did his very best to let me know how dangerous he was, as he would have done if a deer, or horse, or anything else he had reason to fear had come near.

Animal advertising with this purpose, however, is more often addressed to the eye than to the ear, and consists in the wearing and display, sometimes in moments of fear or defiance only, often continuously, of a conspicuous badge, which all the people of the woods recognize as the sign of a creature not to be meddled with with impunity.

The advertisement here takes the form usually of some striking color-marking or badge; and our American skunk has been a classic example ever since Wallace spoke of its broad white bands and bushy white tail. That tail is held aloft as he marches through the grass or along 


\section{The Wit of the Wild \\ 8}

the road in the dusk, and cannot fail to be seen; and you bow before that flag with becoming meekness—or take the consequences!

Another striking example, as familiar in Europe as is the skunk in America, is afforded by the fire-bellied toad, which the Germans call unke. Its upper parts are greenish-black, but the under parts are conspicuously colored bluish-black, with large, irregular red or flame-colored patches. When one of these toads is surprised on land, or roughly touched, it invariably throws back its head, spreads its limbs outward and upward, and curves up its whole body, so that as much as possible of the bright red markings is displayed; and it remains in this position until the danger has disappeared.

"In reality," says Gadow, " this is an exhibition of warning colors, to show the enemy what a dangerous animal he would have to deal with. The secretion of the skin is very poisonous, and the fire-toads are thereby well protected. I know of no creature which will eat or even harm them. I have kept numbers in a large vivarium, together with various snakes, water-tortoises, 


\section{Animals that Advertise}

\&

and crocodiles, but for years the little firebellies remained unmolested, although they shared a pond in which no other frog or newt could live without being eaten."

That such advertising of character and quality has proved serviceable to each race practicing it is implied in the fact that it is most strongly manifested in those of most decided harmfulness in one way or another.

Among insects, for example, many are so distasteful to birds that they go about in broad daylight quite fearless of being snatched by the fly-catchers which compel most insects to fly abroad only under cover of night and hide quietly during daylight hours.

In every case such nasty-tasting insects are now brilliantly colored and are easily recognized, which has been gradually brought about through the fact that the brightest-the most quickly recognized, the best advertisers-survived to perpetuate their kind with an ever-increasing tendency toward more perfect protection, while the less well marked suffered accidents. 


\section{The Wit of the Wild \\ \&}

One has to be very careful in treating a scientific subject in this somewhat figurative style not to give a wrong impression-that is, not to lead the reader to suppose that the changes which have come about toward protective coloration or other beneficial adaptation to its circumstances have been by intention on the part of the animal itself. Hence it is dangerous to say that the trademarks of such advertisers as these last-named insects have been counterfeited.

Nevertheless, that in effect has happened; and many species of butterflies, beetles, etc., which had no noxious qualities, are partaking of the benefits of this color-protection by acquiring a likeness to the bad ones, since birds avoid them under the mistake that they are what their label declares.

Advertisement of warning to other animals that danger threatens may take the form of peculiar cries, or of attitudes, or of a display of colors or of parts of the body. Tell-tale snipe are so called by gunners because the instant they discover the sportsman they begin yelling the news far and wide, arousing the whole marsh. 


\section{Animals that Advertise \\ \&}

Animals like wild sheep, which go in bands about a rough country, are extremely watchful of each other, and need only to see one of their number in an attitude of attention, with head up and ears pricked forward, to become suspicious and ready for flight. The white-tailed deer and pronghorn set their dazzling white scuts erect when their suspicions are aroused, and thus signal (you can see it half a mile away on the plains) to every member of the band to be cautious.

But the most numerous and striking of animal advertisements are those which, as has been said, refer to mating. These are of two classes - the challenges and assembly calls of the males, and the display of their qualities before the females.

Marriage among the higher animals is in many cases a mere seizure of the available females by compulsion and a holding of them by force, and here it is mainly polygamous. Among those which are not polygamous, but are content with a single mate for the season, the choice is made by the female from such males as com- 


\section{The Wit of the Wild}

\section{\&}

pete for her favor. Humanity has not greatly departed from this natural plan.

In any case, competition decides the matter, and this competition may be one in brute strength or of milder qualities, such as attractiveness of shape, color, ornament or voice, or a combination of these.

As the time of the year comes round when mates are to be chosen, the would-be bridegrooms of the first class issue their challenges to all competitors. The alligators make the tropical marshes resound with their hoarse bellowings, and the stagnant pools boil as they rush at one another, clashing their huge jaws and lashing their mighty tails. The victor is lord of the pool and of the horrid harem that lurks among the reeds about its margin.

At the same season the lion roars out his defiance to all other lions, saying: "Come and conquer me if you can; the prize of beauty awaits you if you are better than I!" Then the moonlit sands are dyed with the blood of these kings of the desert, and when the combat is finished sleek golden-eyed queens steal lightly 


\section{Animals that Advertise \\ \&}

out of the shadows and fawn upon the victor of the tournament, who to-morrow must again fight for them in the arena or lose their allegiance.

In northern forests, when the long sweet days of Indian summer suffuse the air with golden radiance, the bull moose and wapiti tell the world the same story of desire. They publish it from hilltop to hilltop in sonorous, bell-like calls that summon eager contestants-for these advertisements never fail of an answer; and if the newcomer can vanquish the old knight of the herd the meek does are his. Many of the smaller animals thus challenge and fight for supremacy. The game-birds do so, and the drumming of our grouse is an announcement of such purpose.

But milder measures prevail in the larger part of animal society, where the beaux seek to recommend themselves to the belles less by prowess than by accomplishments. Their advertisement of a desire to marry is the putting on of gayer dress, or the exhibition of their graces and attractions. Even the "coldblooded" fishes (many of them, at least) glow

$$
\text { or } 111 \text { o }
$$




\section{The Wit of the Wild \\ \&}

with rosy color as the breeding season approaches.

But it is among birds that the display of colors and ornaments to catch the female eye is carried to its highest perfection.

"In the spring a livelier iris Comes upon the burnished dove,"

but it fades-or perhaps wears away, as in the case of the gaudy bobolink-before the summer is over.

In some cases wholly new and conspicuous ornamental feathers come with the spring moult and are not renewed in the fall, so that they seem wholly for the purpose of aiding in courtship. Then these glories of color and ornament are displayed to the best advantage for the choice of the coy hen-birds. For their admiration the great peacock spreads his gorgeous tail, birds of paradise wave their silken plumes in the green half-light of leafy halls, and the hummingbird flashes his gems among the flowers; and it is to woo their bird hearts and hands 


\section{Animals that Advertise \\ \&}

that the songsters chant their sweetest melodies, or chirrup and whistle as best they may.

Now, it is not straining words to speak of all these intentional displays of ability and beauty as advertisements of the desire to marry and the attractions each has to offer. And naturalists say that the females deliberately choose among the competitors, taking the best one according to the standard of each species. Thus the most brightly plumaged males, the best singers, are given the greatest number of chances to mate and perpetuate their race, and to transmit their excellence to their off spring.

The result of this tendency to breed from the strongest and best has been a steady increase of such qualities and a steady growth in these directions. Thus, say those to whom the theory of sexual selection is sufficient to explain all these things, have gradually come about all the gay colors and all the brilliant songs of our birds. 


\section{Animals that Wear Disguises}

\section{\&}

$\mathrm{O}$

NE of our commonest birds is the whippoor-will, yet, though constantly heard, he is rarely seen. This is because he goes abroad only in the hours of darkness.

He does not seek security there by hiding, but squats boldly upon a log. His plumage is mottled gray and brown, like old bark, yet this would not suffice to conceal him if he sat crosswise, as birds generally do, so he sits lengthwise, and at once falls into the appearance of a stub of a broken branch. He disguises himself as a "bump on a log."

But some of his relatives in other parts of the world do even better. Down in the Antilles there is a goatsucker - as all of this family have long been called, though none really rob the goats of their milk, and hence nightjar is a better family name- which is abroad during the 


\section{Animals that Wear Disguises \\ \&}

day, flitting from stump to stump, for it chooses only to alight upon dead stubs. The instant it thinks itself observed it straightens up, stiffens every muscle, and becomes to the eye merely a spike or splinter of its perch.

A large Australian relative, the " more-pork," does this trick so well and quickly that you may almost touch the bird with your cane in pointing it out to a friend, yet the chances are that he will be unable to see it-in fact, more than one person has placed his hand upon a morepork perched upon some fence, without suspecting that it was anything more than a knot, until he touched it.

Both these birds maintain their rigid disguises as long as any reason for alarm remains, and few lose their lives from hawks.

An African member of the family is very conspicuous when it flies about in the dusk by reason of a long, bright feather streaming out from its wings, and it would be in constant peril of discovery and destruction when at rest during the day did it not hide these telltale plumes. So it rests in the grass and lifts its 


\section{The Wit of the Wild \\ \&}

two long wing feathers straight up, where they nod and quiver among the heads of the grasses.

A fish whose name is out of my memory at this moment (but that doesn't matter), has its fins and tail prolonged into queer ragged fringes which would give it a most shredded, disreputable appearance when out of water or swimming in a clear place; but it never does swim naturally in a clear place, but dwells in the midst of floating seaweed, and so disguises itself as a part of the wavering vegetation about it that its enemies must search very carefully to find it.

It is with the same prudence that the slender and defenseless pipefish pretends to be a tall sea-plant, standing almost continuously on his head among the eel grass, where he becomes simply another blade in the little forest of the seashore.

The bittern does the same thing when, fearing discovery, he stands with outstretched neck and bill pointing straight toward the sky, as motionless as a statue as long as you keep quiet. $\mathrm{He}$ has taken advantage of his stripes imitating the 


\section{Animals that Wear Disguises \\ ६}

upright rushes and their shadows, and so has disguised himself as a bit of marsh, and if you walk slowly around him he will turn as if on a pivot and so make no alteration either in his attitude or aspect. In consequence many a silent bittern is never seen at all.

In a somewhat similar way to the seaweedhaunting fishes mentioned above, the South American river turtle called matamata has acquired a disguise which enables it not only to escape its enemy the alligator, but to secure its own prey of fish and little reptiles. Its shell is dark-colored and rough, so that it is imperceptible among the aquatic vegetation amid which the animal lurks, and all over its brownblack head and long neck, outstretched and ready to seize its victims, grow a multitude of strings and knobs of dark skin which so precisely imitate a plant stem that often a fish will swim unsuspectingly right into its jaws.

The great cayman himself may be said to assume the appearance of a knobbed and slimy drift $\log$ as he lies on the mud of the river margin or floats motionless at the surface of the 


\section{The Wit of the Wild \\ \&}

water, and not only has many an animal walked or swam within his reach without a thought of his presence, but man himself is frequently deceived.

Very different in circumstances, but the same in intent, is the disguise of the sloth as a bunch of "old man's beard" moss, for as he hangs after his manner from the underside of a limb in a Brazilian forest, his coarse gray hair so perfectly resembles the mossy draping of the trees that no casual eye would suspect that a living animal was there in place of it.

It is among insects, crabs, etc., that the most perfect disguises are found, as also are the most perfect cases of " mimicry," by which term we may distinguish those resemblances which imitate some other creature for which it is to an animal's advantage to be mistaken.

Occasionally in late summer, when my eyes are fixed, perhaps in idle gaze, upon a bush, I am startled to see a twig suddenly walk off, and thus I find I have been looking at a walkingstick insect without seeing it. This is a relative of the grasshopper which is drawn out until 


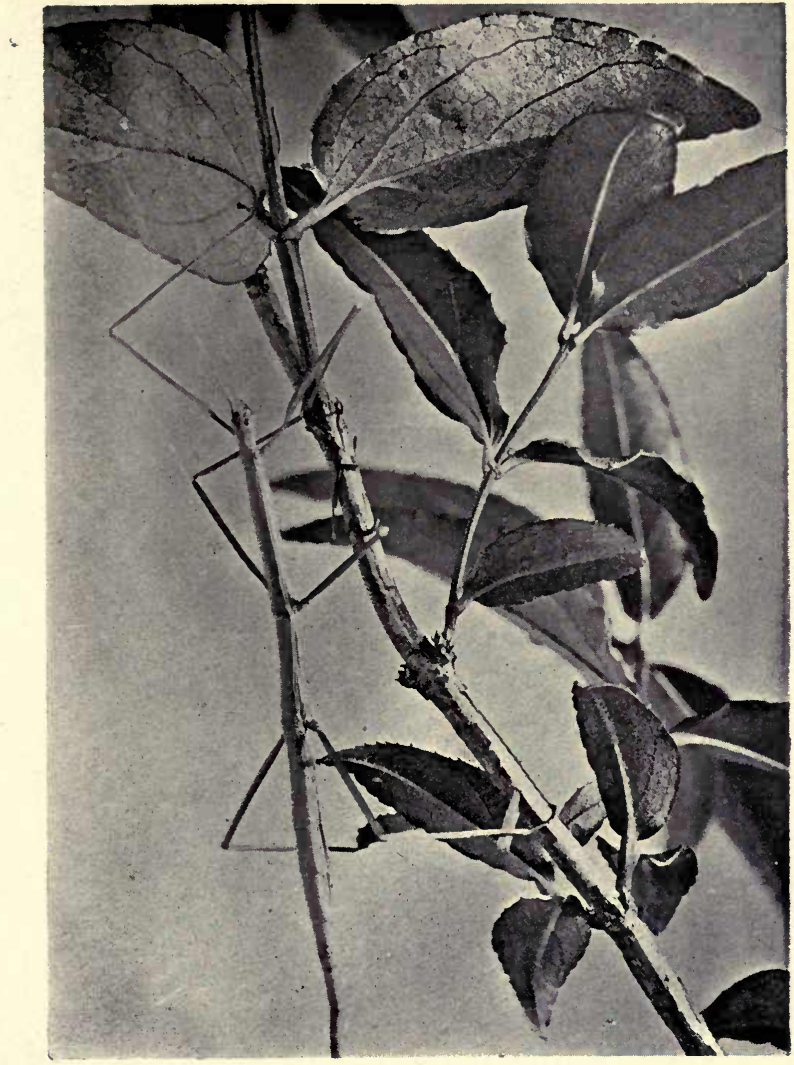

L W. Brownell, Phot.

A Twig-like Walking-stick Insect 


\section{Animals that Wear Disguises \\ \&}

its body, gray or light brown in color, looks much like a stick from two to six inches long, and its legs are prolonged into wiry appendages equally dry and twig-like. In the tropics the walking-sticks are large, varied and numerous, and Alfred Russel Wallace tells of one which he found in the East Indies whose body was covered by little greenish excrescences that perfectly resembled a kind of wood moss common on the trees there, so much so that even the sharp-eyed Dyaks were completely deceived. These dry stick-like insects walk slowly about the twigs of trees, feeding upon the juices of the bark, and have no means of defense against nor escape from birds, monkeys and other insect-eaters, except to trust to their invisibility.

The same need of protection against the danger of being eaten causes many moths and butterflies to assume the disguises of a dead leaf whenever they rest. Every one knows that as a rule moths are dully colored on the upper side of their wings, which lie out flat when the moth is at rest, whereas in butterflies the brilliant tints are upon the upper side while the under- 


\section{The Wit of the Wild}

\section{\&}

side is plainly colored - a fact which goes with the ordinary habit of butterflies of sitting with their wings closed and held upright over their backs, so that the gay colors are hidden and only the plain undersides are exposed.

In some butterflies of the tropics this disguise is the most perfect probably of all in the animal kingdom. The kallima, a common butterfly of India and Sumatra, simply disappears when it settles on a bush, for it hides its head and antennæ between its closed wings, which in form, color and veining cannot be distinguished from a withered leaf. The likeness is complete, even to the discolored spots, broken places and bent footstalks. One may safely defy the keenest eye to find the living insect among the leaves, and you may go as close as you please to examine it, for the butterfly understands perfectly well that its disguise is impenetrable as long as it holds still. Scarcely less puzzling cloaks of invisibility are worn by many other butterflies and by various sorts of more or less sedentary insects.

Sometimes. however, mimicry is assumed not 


\section{Animals that Wear Disguises ६}

for protection against foes, but to assist the creature in getting its living. Belt tells of his surprise in Nicaragua at finding what he supposed the dropping of some large bird on the leaves of a bush to be really a voracious spider lying in wait for victims. When it drew in its legs and squatted in this disguise no bug would ever suspect any harm, and at the same time the spider itself was safeguarded, because there was no likelihood that any of its enemies (mostly birds) would pay it any attention, except to avoid it.

This is one of the most extraordinary and most effectual disguises that have been discovered; but the more naturalists investigate the ways and means of the lower orders of life, the more they find nature utilizing these protective resemblances. 


\section{Birds and Beasts that Bluff}

\section{\&}

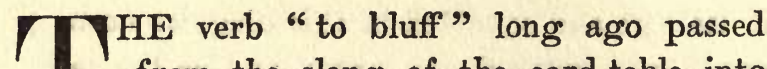
from the slang of the card-table into 1 truly respectable if not elegant speech. It expresses more precisely and forcibly than anything else the idea of dissembling unconfessed weakness by a bold and defiant attitudethe legitimate, justifiable attempt at deception in self-defense which is a part of the armament of every creature. For, after all, bluffing is nothing else than an attempt to make your antagonist believe you bigger or stronger than you are, or, perhaps, than he is; and thus it becomes the natural tactics of the weak against the powerful.

The gambler who holds a strong hand has no need of this resource; it is the resort of the player who, lacking munitions for his war, must set up a pretense of strength that shall frighten 


\section{Birds and Beasts that Bluff}

\section{\&}

his adversary. This is nothing new. Most men and all women are bluffers, and every animal is an adept at the art within its own range of experience, while the less actual ability it has to use them, the more inclined it is to put up its fists.

Take, for instance, the caterpillar of a sphinx moth-a slow, fat, green worm, crawling sluggishly about the bushes in plain view of every insect-eater. It has no armor, or spines, or poison, or ability to defend itself whatever, but the instant anything approaches it it rears up and wags its horned head and looks so formidable that almost nothing has the nerve to tackle it. This is purely a bluff.

Consider the case of that harmless braggart, the hog-nose snake. He can really hurt nothing bigger than a mouse or a fledgling sparrow, and he lives mainly on ground beetles and worms, yet he has to be on his guard against hawks, owls, skunks, blacksnakes and various other serpent-eaters, in respect to all of which he is full of cowardly fear. But he is so slow that he cannot run; he can wield no poisoned stilettos, 


\section{The Wit of the Wild}

\section{\&}

as do the rattlesnake and copperhead; and hence must rely entirely upon inspiring terror.

So he swells out his head and neck to twice their size by expanding his ribs, opens a great triangular mouth, blows and hisses, and makes believe he is the ugliest sort of viper-and as a rule succeeds well enough to be left alone. If you "call" his bluff he will fall limp and literally go into convulsions of terror, or turn over on his back in a dead faint of fear before you have really injured him at all.

The dreadful East Indian viper which the Portuguese pioneers in India named cobra de capello- the hooded snake-has the same idea when he lifts a third of his length and presents his immensely distended head and neck in the face of a leopard or other threatening foe. $\mathrm{He}$ has good weapons, but few animals fight unless compelled to do so, and he tries to avoid it by a bluff.

In fact almost all animals, when they find that shrinking out of sight fails to cause them to be overlooked, immediately try to make themselves as big as they can to produce fright. We 


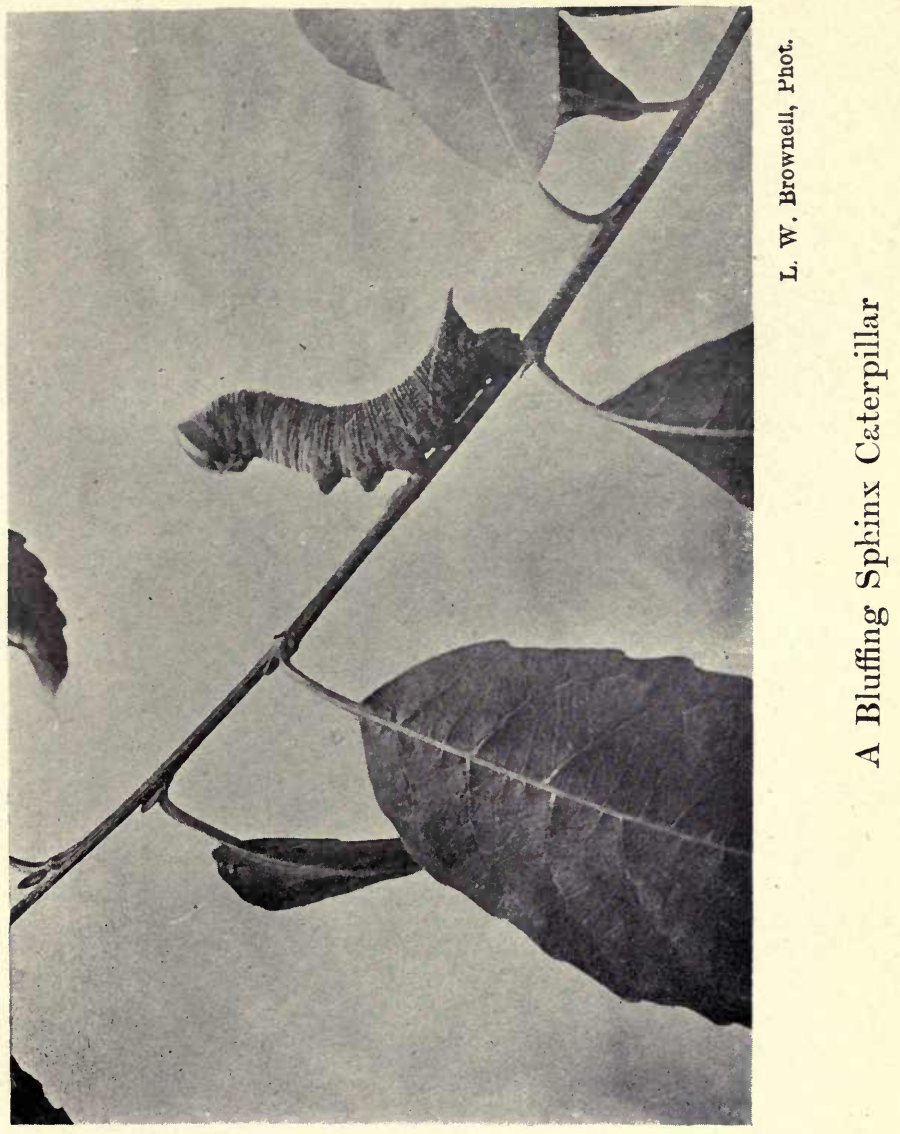





\section{Birds and Beasts that Bluff}

\section{६}

borrow the simile from them when we say of a truculent fellow that he "bristles up." That is the notion of a wolf or dog when he lifts his hackles and rises on tip-toe to meet his challenger; and of puss when she sets every hair on end, arches her spine and swells her tail to thrice its peaceful girth.

When the fight actually comes on they forget all these blustering preparations, which were merely terrifying tactics, like the bellowing and pawing of a bull, the war-paint and rattles of the Indian, or the yelling and firecrackers of the Chinese before a battle.

The porcupine is one of the best of the blusterers, for he not only turns himself into a living chestnut burr, but rattles his quills against one another like some mediæval knight jangling all his war harness as he enters the joust to proclaim how impregnable he is and at the same time to hearten himself up a bit. If the porcupine shivered with fright the same rattling of the hollow quills would follow, and perhaps, if the truth were known, that is really what happens. At any rate he doesn't shoot his quills as the old 


\section{The Wit of the Wild}

\section{\&}

stories alleged, yet he might almost as well do so, for the slightest touch will cause their needlelike barbed points to adhere to any soft surface, and they are pulled out and carried away by the enemy as souvenirs of a fruitless encounter far more difficult to get rid of than to acquire.

Few of the woodland animals are unaware of this, and consequently nothing but the foolishness of youth, or the desperation of extreme hunger, will lead any beast of prey to forget the warning of the rattling quills and leap upon their tender-fleshed but bristling owner. Some of the smaller ones, like the fisher marten, do, however, get him by strategy,-creeping beneath the snow in winter and seizing his unprotected throat or belly in a fatal nip. Against such an attack, by what soldiers would call "sapping and mining," the poor porcupine can make little defense.

A good many bugs and some caterpillars and crustaceans have an armament somewhat similar to that of the "fretful porcupine," but these behave more like the hedgehog, simply rolling up so that their points stand out in every direc- 


\section{Birds and Beasts that Bluff}

\section{\&}

tion and defy the enemy to find an exposed point for attack.

There is one sort of fish, however, represented by several species in Northern seas, as well as many in the tropics, which combines a strong disposition to bluff with a very good "hand." This is the tribe of globe-fish or porcupine fish, of which the little puffer or swell-doodle of our Atlantic coast is a good example.

These fishes when quiet look much like others, except that they have a rough, leathery skin instead of a scaly one, and are everywhere (except along the abdomen) covered with bristlelike appendages. Let one of them be alarmed in any way, however, and an almost instantaneous change takes place. It sucks in water by rapid gulps until it swells into a ball studded with stiff spikes. In this condition it rises to the surface of the water and spins and bobs about, giving queer audible grunts, and making a most extraordinary and to our eyes comical appearance.

This is enough to make 'most any thoughtful fish repent the error of its intention, and 


\section{The Wit of the Wild}

\section{\&}

leave the uncanny thing alone, but if, misguidedly, it still tries to seize it, it finds the grunting, prickly little globe something it is indisposed to swallow and hastily spits it out. As a matter of fact the spines of the globe-fish are neither hard or venomous and would do no harm, but the little fellow succeeds in life as well as if he wore a real armor, because he makes his foes think him a real terror.

The processes of natural selection have worked steadily among birds, fishes and beasts toward making this faculty of bluffing more and more successful as a means of self-protection, and have supplied many means to that end.

An owl and various other birds throw their wings out or forward and use them well in a struggle, but one-the magnificent argus pheasant-spreads them in front of him, which not only magnifies his warlike appearance, but serves as a shield in the combat that may not always be avoided. The wings, in fact, so well form a round screen in front of the bird that it can withdraw its head altogether behind it, 

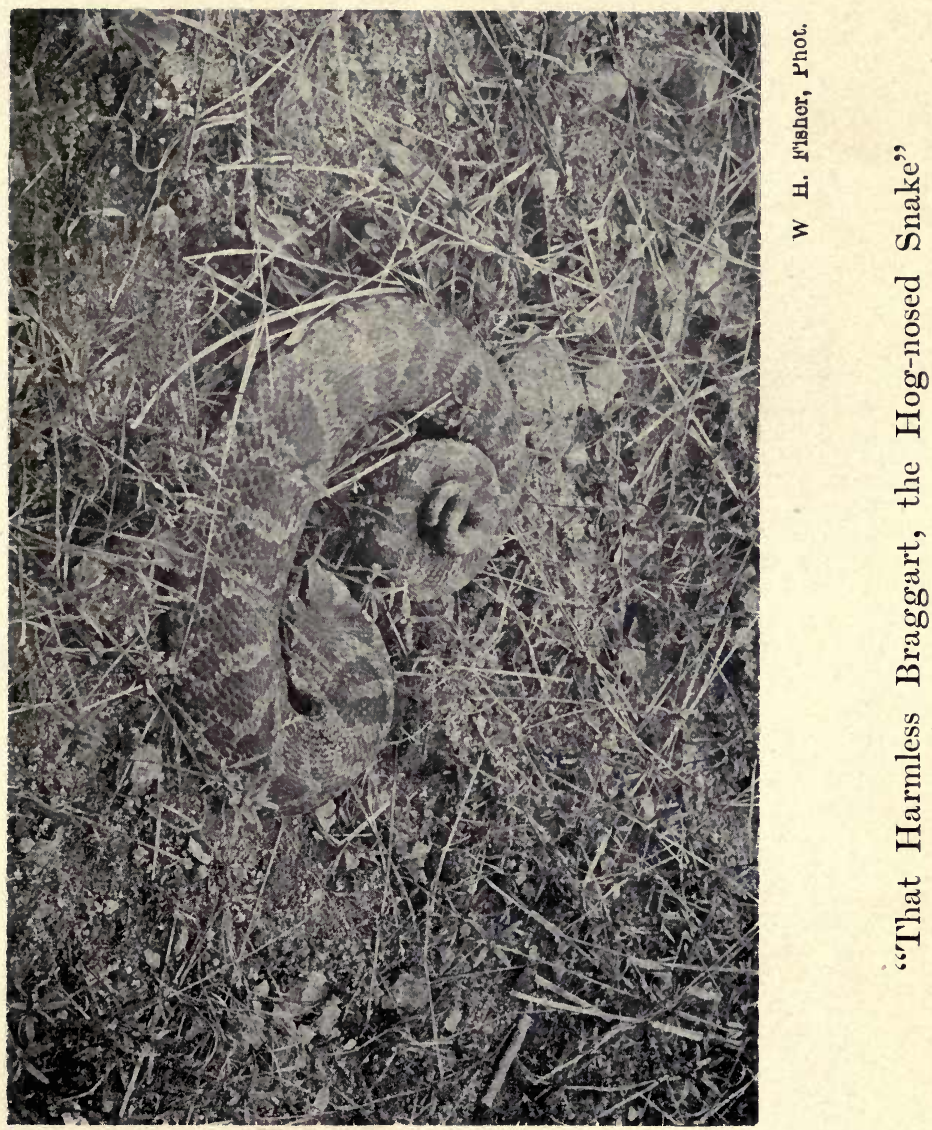



\section{Birds and Beasts that Bluff}

\section{\&}

and then strike through it at its antagonist in some altogether unexpected place.

Tactics of this kind are said to be a part of the secret of the extraordinary success the ground hornbill of South Africa has in killing the dreadful puffing-adder and other deadly snakes of that region which it likes to eat. On discovering a snake three or four of the birds advance sideways toward it with wings stretched out and with their quills flap at and irritate the snake till it strikes their wing-feathers, when they immediately close in on all sides, and violently peck it with their long, sharp bills, quickly withdrawing again when the snake lets go. This they repeat until the snake is dead. If the reptile advances the bird places both wings in front of it, completely covering its head and most vulnerable parts, just as does the argus pheasant.

All the lizards, having little ability for real harm in them, are great braggarts, and seem to know well how to profit by their spinycrested, diabolically ugly features.

There is one sort, however, which has special 


\section{The Wit of the Wild \\ \&}

means for "putting up a bluff" in its vast Elizabethan collar or "frill." This consists of a great outgrowth of flesh from behind the ears all the way round under the throat. It is as though the head of the animal were pushed through an umbrella, which lies folded back upon its fore shoulders in ordinary moments.

This lizard is an inhabitant of Australia and sometimes reaches three feet in length. It seeks its food both in trees and on the ground, where it runs swiftly, and is often seen about gardens. When not disturbed it moves quietly about, but it is highly irascible and the instant it is provoked opens its frills and makes for a tree, where, if overtaken, it throws itself on its haunches, raises its front as high as possible and sinks its head between its shoulders in the center of an inverted umbrella studded with spines and prickles.

It would certainly be difficult to invent a picture of armament, rage and disgusting qualities all together, to exceed this bit of acting, and it is sufficient, many a time, to warn off the attacker who had not thought a peaceful-look- 


\section{Birds and Beasts that Bluff

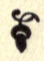

ing lizard would make a lightning change into something satanic.

As a matter of fact animals are probably able to bluff more effectively than men, because they are in such deadly earnest about it and do it so often. 


\section{A Good Habit Gone Wrong}

\section{\&}

П AKE him by and large probably none $^{\mathrm{AKE}}$ of our American animals is more inter1 esting to a thoughtful person than the gray, grunting, snarling, pilfering, dunderheaded and motherly creature which the southern Indians told us was an opossum. John Smith reported among the wonders of Virginia: "The opassam hath a head like a Swine, a tayle like a Bat, as bigge as a Cat, and hath under her belly a Bag wherein she carrieth her Young." No need for mistake in identifying this creature, though in respect to some of the other "marvels" of those early reporters naturalists are guessing yet.

It was the distinction of our opossum to be the first of all marsupials to be brought to the knowledge of the civilized world, and some of the early notions as to the method of its novel reproduction are among the most grotesque $\infty 132$ 


\section{A Good Habit Gone Wrong \\ \&}

relics of the early stages of zoölogy. More than two hundred years elapsed before the matter was understood aright, so far as can be learned; and then it was the study of our little old opossum, and not of the numerous and diversified marsupials of Australia, which solved the puzzle.

Another, and perhaps more lasting distinction, is that of adding a phrase to the language, - "playing 'possum." It needs no definition. Everybody understands the nature of the ruse signified, yet not all know the circumstances under which it is practiced; and so far as I know no one has asked, not to speak of answering, the question how the little beast acquired the idea, or habit, or whatever it is that causes him to "go dead," - why he plays 'possum.

In the first place it appears that the animal remains wide-awake and fights as briskly as any other on many occasions, so that the use of the ruse is by no means invariable. A mother with half-grown young, for example, will sit up on her haunches and face an enemy with gleaming eyes and teeth, without a thought 


\section{The Wit of the Wild \\ \&}

of taking refuge in coma; and in the season of courtship all the males go about with a chip on their shoulders, seeking and carrying on terrific fights, in which neither combatant lies down until he has to,-and then his foe makes sure that the death is real before he quits. Dr. Lincecum tells how he went close to such a battle once and watched it a long time, the furious rivals being too busy to mind him; then " kicked over" the female, "who went into a spasm." All predatory animals seem to bear the creature enmity, yet few or none devour it. Dogs take every opportunity to crack its bones, and from them the opossum tries to escape, when he hears them in time, by hastening up a tree. In a great number of cases of danger, in fact, as all accounts agree, the animal does its best to utilize ordinary methods of escape or defense, running or hiding or fighting in a perfectly natural way. In other cases, just what or when it would be hard to define exactly - but apparently in the presence of something so large as to make resistance idle,- the animal, when attacked or cornered, will fall limp and "dead"; " and when 


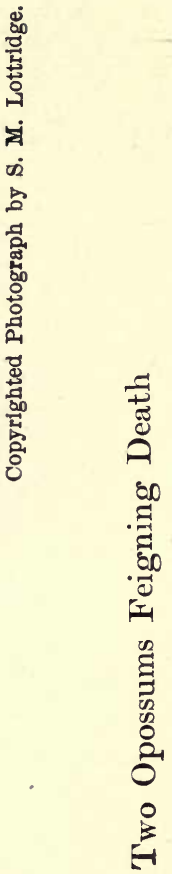

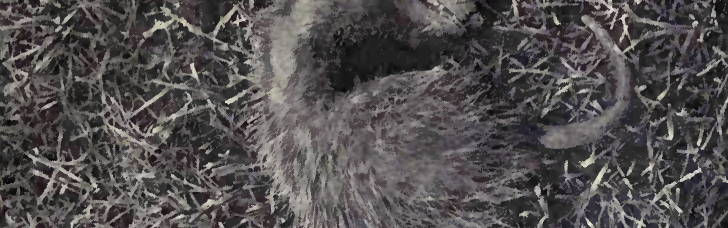

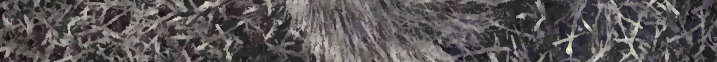

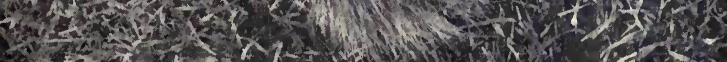

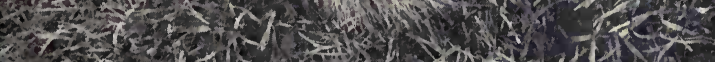

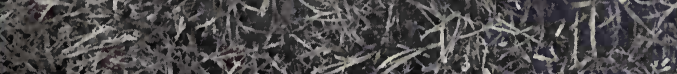
3.t. (a)

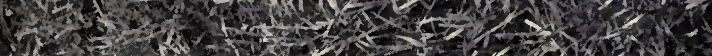





\section{A Good Habit Gone Wrong \\ \&}

the opossum plays 'possum," as Witmer Stone remarks, "he invariably draws back the gums from his glittering white teeth until he looks as if he had been dead for a month." You may roll the creature about with your foot, explore the pouch, pick it up and carry it by its tail, offer it almost any indignity, and it will in most cases neither resist nor complain; but take your eye off it as it lies upon the ground, and it will soon jump up and scuttle away, or if you pick it up carelessly enough to give it a chance it may nip you savagely. Severely injured, as in the jaws of a big dog, or under the club of a darkey eager to sop sweet potatoes in 'possum gravy, the animal protests, but yields as if utterly discouraged.

This behavior does not bear out the theory held by some naturalists, that the action is not a ruse, but an involuntary paralysis due to sudden, hysterical fear; to one who knows the creature nervousness and hysterics are the last things to be thought of. It will hardly do then to believe it a physiological effect; and yet it is exercised in so irregular and often useless 


\section{The Wit of the Wild \\ \&}

and dunderheaded a way that it seems hardly worthy the name of an intellectual performance, like the fox's use, on occasion, of a similar device in stalking or ambushing his prey. It looks to me more like the action of an instinct which has lost its steering gear-an instinct that has outgrown the circumstances which originated it and in which it was advantageous.

Of what service now is the time-honored ruse? How many of the opossum's enemies are now sufficiently deceived by his little game to go away and leave him? Would a cat or a dog, a wolf or a big owl, neglect to seize and eat him (if they cared to-dogs won't touch the flesh) because of his pretense? What do they care whether he is dead or not-if the former, so much the easier for them. But their noses tell them better. Dr. Lincecum says that in Texas he has repeatedly seen turkey buzzards alight " near where they find an opossum feeding in the woods and, running up on him, flap their wings violently over him a few times, when the opossum goes into a spasm, and the buzzards very deliberately proceed to pick out its ex- 


\section{A Good Habit Gone Wrong \\ \&}

posed eye, and generally take a pretty good bite from its neck and shoulders, the opossum lying on its side all the time and grunting." If then the feint (or faint?) does not deceive, of what service is it? On the contrary, is it not a fatal mistake in tactics, leading to death by tame submission many an opossum which might otherwise save himself by fight or flight? Hence the practice seems to me an obsolete survival from some time and place in the past history of the race when such a habit was serviceable. Let us see whether any exterior evidence exists to justify this proposition.

It is now known - and it is only very recently that the facts have become clearly establishedthat the opossums are traceable farther back than any other family of mammals; theirs is the group lowest in organization, and most ancient in lineage. Long before the dawn (Eocene Period) of the Tertiary Era, or "Age of Mammals,"-away back in the Cretaceous division of the preceding Mesozoic time,-the opossum race was well defined and established. Still more remarkable is the fact that from that 


\section{The Wit of the Wild}

\&

time to this the variation it has undergone has been extremely small, - so small that the teeth found fossil in the Laramie formations of Wyoming are hardly distinguishable from those of the "'possum-up-a-gum-tree" to-day.

Now it must be remembered that the world of that era was peopled almost wholly, so far as interested opossums of the time, with predacious reptiles, brutes often of enormous size and strength but of low and sluggish nervous organization. The relatively minute size and smooth interior of their brain-boxes show that their brains were of little value as instruments of intelligence, and all their senses were doubtless far inferior to those even of the dull-witted, sluggish crocodilians, lizards and turtles of the present. Small objects would not attract their attention unless they moved, and a little animal remaining absolutely motionless would in most cases be overlooked, or if seen would not be attacked. Put a tree-toad in a cage with a bull-frog to-day and the little one will be safe from his ravenous neighbor, no matter how near he sits, until he makes a move. Should the crea- 


\section{A Good Habit Gone Wrong}

\&

ture's odor penetrate the dull nostrils of the foe, and an examination follow, if the prey had resolution enough to continue its quiet position, so that it would appear to be dead, even with a great dinosaur nose poking at it, it would probably be left untouched, for, as a rule, land reptiles do not feed upon carrion.

An ability of this self-preserving kind would be almost a corollary of existence under the circumstances in which the Mesozoic opossums found themselves; the habit would be of a nature most likely to be advanced by natural selection; and in the course of the immensely long time available for producing the effect the practice would become thoroughly ingrained into opossum nature. But after a while the great stupid reptiles died out and were gradually replaced by hunters and foes alert in perception, quickwitted and active. An adaptive, plastic sort of animal would have shaped habits and structure to the new circumstances as they arose: but the opossum nature is not of that kind,- - perhaps no other has been physically so inflexible; and along with its unchanging body has gone a 


\section{The Wit of the Wild \&}

rigidity of mind which has retained habits so long beyond their usefulness that now they are detrimental. So far is the practice of "feigning death " from being, as is popularly thought, a wonderful provision for safety, that to its habit of "playing "possum" the race may attribute, more than to any other one thing, its present restricted range in the world, and its steady decadence in numbers. 


\section{Animals That Set Traps}

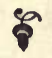

NIMALS must work for their living or they won't get it any more than would their human superiors. Now and then one may find itself a sort of millionaire-so favorably situated that it gets all its needs without any special exertion. But this is rare -at any rate among the higher sort which lead an active life.

The great and varied army of roving animals, little and big, whether inhabiting the waters or the air, or wandering about the land, must " hustle" night and day or they will get left in the constant race and struggle for daily bread. They vary immensely in their means and abilities, and hence must pursue vastly different methods, constantly devise new schemes, to outwit their would-be victims and keep even with their competitors. In this way a good many have learned how to make ambushes, set 


\section{The .Wit of the Wild \\ \&}

traps, or throw out lures which shall bring their prey to them, or at least enable them to get near enough unobserved to pounce upon it.

This is a large part of the service of what is called "protective coloring" - that is, the possession (by slow acquirement in the course of many generations) of colors that correspond so closely with the creature's customary surroundings as to make it unnoticeable when quiet.

The colors of the tree-frog, for example, which modify themselves by almost immediate change to precisely accord with the hue of the bark upon which he sits, hide him not only from his enemies, but make him look so much like a knot on the branch, that the insects running about the trees never see him until they have run right against his nose and the next instant find themselves stuck to the tongue he has darted out and traveling down his throat. The same is true of the garden toad, as he sits as quiet and brown as a lump of earth among the grass roots and seizes the flies and bugs that blunder within reach, never noticing the ogre until it is too late. 


\section{'Animals that Set Traps}

\section{\&}

Many crabs are dark green, like the eel-grass where they love to lurk. They feed upon all sorts of small swimming creatures and do not chase them much, but back into a tangle of grass along some little path and keep perfectly still in wait for a victim, upon which they leap like a Zulu ambushed beside a jungle path.

Almost innumerable are the examples that might be quoted of these tactics among animals of prey in almost all the active classes-even among the birds. For instance, herons that feed on fish get them usually by standing immovable in the water and waiting until one comes unsuspectingly near, when the spear-like beak is thrust through it with a downward stroke of amazing rapidity. It used to be said that the heron had the power of making a mysterious tuft of feathers on its breast glow with phosphorescent light, attractive to its prey, while at the same time it lighted the water so that the bird could see where to strike. This story has all the advantage of a good illustration for us, except truth!

Some, however, are too impatient to wait in 


\section{The Wit of the Wild \\ \&}

this manner, but drum up their prey. Thus the African saddle-billed stork runs about in shallow water and then strikes at the fish that try to escape past it; while an ibis of Ceylon stirs up the bottom with its foot and then picks one after another the mudfish that are aroused.

Many animals, however, improve upon the methods described by setting traps and using decoys and lures of one sort or another to attract prey to them. Familiar to most students is the method of the goose-fish, or angler, a big, repulsive, voracious fish of our coast, which dwells at the bottom in shallow water, half smothered in mud no blacker than its own body. From the top of the lips of this fish there stands up a feeler several inches in length which trembles in the water like a tasseled whiplash. This is sure to attract the eye of small fishes cruising about, who mistake it for a bug or something else fit to eat, and will dart at it, only to find themselves seized by the horrid mouth that lies beneath.

In a similar way the puma (or panther) gets itself many a meal otherwise difficult of attain- 


\section{Animals that Set Traps \\ ६}

ment, if the guachos of the Argentina pampas are to be believed-and they ought to know. When one of these great cats seeking for food spies a herd of guanacos on the plain he steals as near as he can (always, of course, up the wind) and crouches flat upon the ground. Then he lifts his tail and begins to wave the end of it above the grass. The sharp-eyed guanacos soon catch sight of it and draw nearer and nearer to investigate this strange freak. They gather closer and circle around the cat, coming closer and closer with fatuous craving to understand it, until the puma strikes one down. This fact may be true, without requiring us to believe that the puma lifts and waves its tail with a deliberate purpose to attract his prey; it may be done out of habit, or nervous eagerness, quite unconsciously in respect to the effect.

It has been surmised that the nervously: wavering tail of the coiled serpent intent upon prey was really the instrument of what is called its fascination for the bird or squirrel upon which its eye is fixed. If so, this wavering 


\section{The Wit of the Wild}

\section{\&}

tail, like that of the puma, becomes a true lure; but whether it is the gratification of curiosity or a gloating over danger or a wish to punish the reptile that causes the little animals to be too venturesome, certainly many seem to hover about a serpent until they are caught.

Every spider's web is a snare before the feet and wings of the unwary. These nets of glutinous thread are set where the insects upon which spiders subsist are passing, and they are constructed with marvelous skill. The spider builds them as accurately as she can, and then goes about pulling the tiny cables here and there with precise judgment of the proper tension in order to make sure that all is right. The net must be elastic enough not to break under the first struggles of the prisoner, yet must not be so loose that he can push through. Some of these spider snares are several feet in diameter and frequently they are strong enough to capture small birds or mice.

Analogous to this is the small net of silken threads spun by the caddis-worms of certain species common in all our swifter streams, which 


\section{Animals that Set Traps \\ \&}

are spread between pebbles, or across crevices in rocks, and serve as true gill-nets to capture minute swimming creatures upon which caddisworms feed, but which they could not otherwise catch in sufficient abundance.

Another familiar and pertinent example is that of the pit of the ant-lion, - a true trap. The larva of the tiger-beetle, whose widely opened jaws fill the mouth of his burrow, is a living trap, made to snap, precisely like a furhunter's steel-trap, on the heedless insect that steps into it.

The jelly-fish as it sails gracefully through the surface of the sea is another living trap of the most deadly kind. There is floating about him in all directions, and to a distance (in the largest ones) of several feet, a perfect tangle of extremely delicate ribbons, like the flying hair of a Medusa head, which are as transparent as glass and as deadly as poison to all small swimmers. Let a minnow or shrimp or some one of the hundreds of sorts of young creatures that float in the ocean run against these unseen threads, and they will cling to him, envelop him 


\section{The .Wit of the Wild}

\section{$\$$}

in multiplied and ever-fastening threads from which there exudes a poison that paralyzes his efforts. And so he is caught and held, and gradually brought up to the body of the jellyfish to be devoured. Now, this is not only a living trap, but includes a lure as well, for the jelly-fish is phosphorescent, and its pulsating flashes of light attract the attention of the small creatures who swim toward their ruin. Undoubtedly one of the effects, if not purposes (a word that must be used very cautiously in natural history), of the phosphorescence that belongs to so many marine animals is to act as an attraction to animals that are needed as food.

It has not been known until recently that birds do anything in the way of luring victims within their power-or at any rate, anything further than the use our sapsucker makes of his "honey-pots." This bird is the American yellow-bellied woodpecker, which digs hundreds of little pits in the bark of sweet-sapped trees such as the apple, basswood and maple (producing in the last-named injuries that result in "bird's-eye maple"), and greedily drinks the 


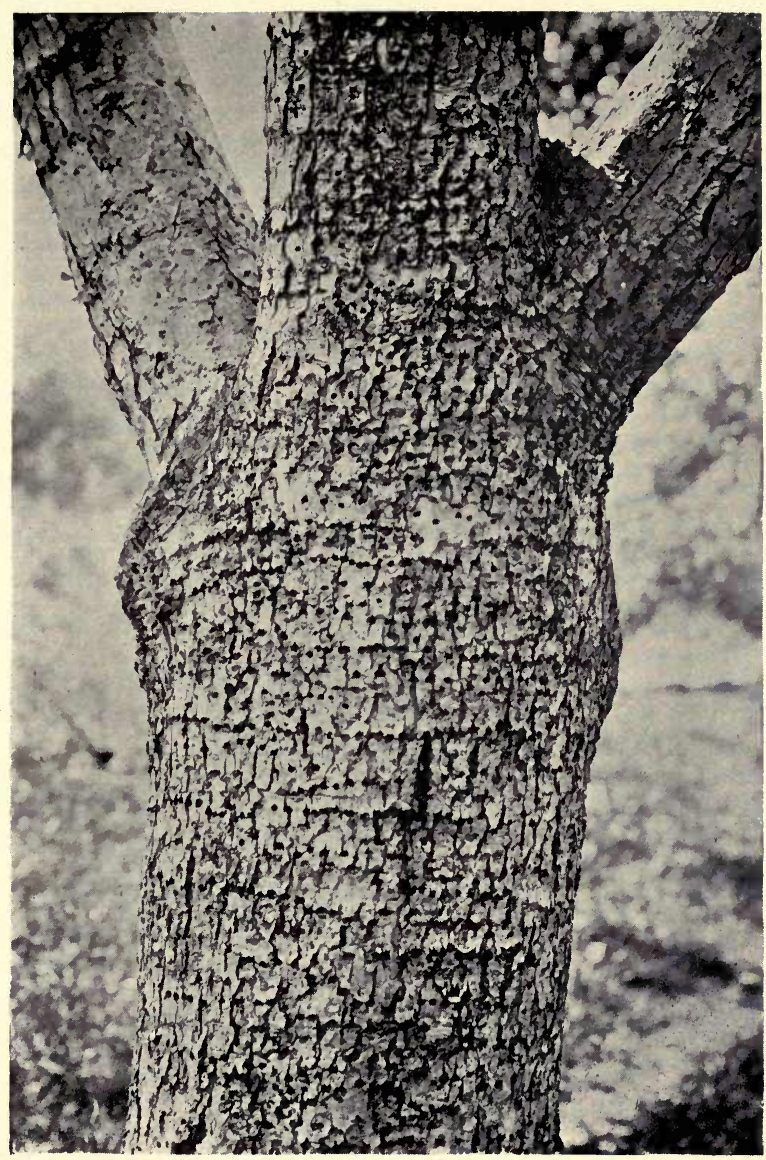

c. Lown, Phot.

Sapsucker Work on an Apple Tree 



\section{Animals that Set Traps \\ \&}

sap which exudes besides eating a certain quantity of the layer of soft growing wood beneath the bark. But it has been shown by experiments with captives that when fed wholly or mainly upon this sap the bird starves. The larger part of its fare, in fact, must consist of insects, and some naturalists believe that the primary object of the woodpecker in digging his circles of holes in the tree-bark is to form a bait for insects. Certain it is, that as soon as the sap flows insects gather and buzz in swarms about the honeyed exudation, and that the bird returns again and again during the day to his tree, gathering the bugs that have been caught in the sticky little cups or in the drippings on the bark, or snapping them from the air, as he is very skillful in doing.

In Teneriffe two warblers, familiar in Great Britain as the blackcap and the garden warbler, are each accustomed to puncture the calyx of certain large flowers, particularly those of the hibiscus and abutilon, causing a little sweet liquor to exude from the nectarous juices of the blossom. This is attractive to many small 


\section{The Wit of the Wild}

\section{\&}

insects, and the birds make the rounds of their punctured flowers and so obtain food without the need of hunting.

How far the result obtained is intentional on the part of these birds is a moot point, but at any rate it may be accepted as fostered by natural selection and has now, perhaps, become instinctive. 


\section{Animal Partnerships}

\section{\&}

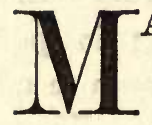

ANY animals go into partnerships with others. Sometimes it is a union of the strong with the weak, and the benefit, so far as we can see, is wholly one-sided, but of ten visible advantage results to both.

Jackals and hyenas that dog the steps of lions in order to crack the bones left from the royal feast can be of service only rarely, as sentinels; and what return can be made by the remora? This is the queerly striped "sucking fish," which attaches itself by the sucker on the top of its head to a turtle or shark or swordfish and is carried about free for hundreds of miles, having nothing to do but dart aside here and there to snatch up a bit of food and then resume its dead-heading.

The partnership between the shark and the pilot fish, however, seems to be one of mutual service, the little one accepting the protection 


\section{The Wit of the Wild}

\section{\&}

of his wonderful patron, and in recompense acting as intelligence officer and guide.

Mosely gives a most interesting account of their scouting for the master; and he also mentions the habitual attendance, in the South Seas, of a petrel upon the whale; but the principal "whale-bird" is a small snipe-like creature of the Arctic regions called a phalarope. These abound in Greenland waters, and they assemble in flocks about every whale that basks upon the surface, as the whales often do, alighting upon its back and industriously cleaning it of the small crustaceous parasites that attach themselves to the leviathan's skin, often in hundreds of thousands. The monster of the deep floats contentedly on the surface and lets his little friends pull out and eat the annoying "lice" as though he really appreciated the favor.

Another very curious partnership of the sea is that between certain large Medusæ or seajellies and small fishes. The jellies consist of an umbrella-shaped body, which looks like glass, and from the under side of which trail great bunches of filmy threads and some larger cur- 


\section{Animal Partnerships \\ \&}

tains. These tentacles are endowed with stinging power, by means of which the jellies benumb what they seek to catch as food and then hoist it up to the "mouth" in the under surface of their floating disk. Now, certain little fishes, which are exposed to a multitude of enemies in the open sea, are in the habit of taking shelter right among the poisonous tentacles of the medusa, where, for the time, they are safe from any outside harm and where a good deal of food falls in their way; but the capital they put into this strange partnership is their lives, for if they travel about long enough with their dangerous "protector" they are certain one day to be wrapped in the fatal net and eaten. So this is jumping from the pan into the fire; but it is an illustration of the hard straits that sea animals are put to to preserve life even for a little while.

Many other curious instances of permanent association among the humbler denizens of the sea might be mentioned, but their description comes under a different head, for they are parasites or messmates, rather than partners. 


\section{The Wit of the Wild \\ \&}

It is among birds that the most interesting examples of partnership are found-sometimes with other birds and often with animals of another class. That familiar little company of our winter woods - the downy woodpecker, nuthatch and chickadee-is a mutual aid society, not only enjoying each other's companionship, but profiting by their varied ways of searching for similar fare, and especially by the powerful pickax of the woodpecker, which uncovers many a tidbit his friends could not get at with their weaker bills. Birds are friendly creatures as a rule, and of ten nest in companies, not only in rookeries of their own kind alone, but by various species carrying on their domestic life in close proximity yet peaceably, and all rallying to defend the whole community against threatened dangers. Sometimes the association is closer.

Thus it of ten happens that the huge nests occupied year after year along our coasts by the fish-hawks will be dotted among the sticks on the outside with the nests of blackbirds, which raise their young comfortably beneath the 


\section{Animal Partnerships \\ \&}

shadow of the great hawk's wings; and the same thing has been noted in the nests of the whistling sea-eagle of Australia, which harbors in the niches of its castle the home of a small finch, the diminutive tenants getting along most amicably with their powerful host.

At the other extreme is the curious voluntary association of birds with ants and wasps for the sake of safety for their homes. Gosse tells us, in his "Naturalist in Jamaica," that in that island a small seed-eater called the grass-quit often selects a shrub on which wasps have built and fixes the entrance to its domed nest close to their cells; and Prince Maximilian Neuwied states, in his "Travels in Brazil," that he found the curious purse-shaped nest of one of the todies constantly placed near the nests of wasps, and that the natives informed him that it did so to secure itself against attacks by its enemies. The mocking-birds in Guiana are said to do the same thing to guard themselves from thievish monkeys.

Alluding to this, that excellent observer, Thomas Belt, remarks that one would think it 


\section{The .Wit of the .Wild \\ \&}

likely that the birds when building their nests would be very likely to be attacked by the wasps, and that this does not happen is good evidence of an acknowledged "partnership." However, it is to be noticed that nests in such a situation are usually domed-that is, have a cap or cover, as if the birds thought the wasps neighbors of very uncertain temper.

Belt himself instances the similar case of a Nicaraguan fly-catcher. "On the Savannahs, between Acoyapo and Naucital," he says, " there is a shrub with sharp curved prickles, called viena paraca (come here) by the Spaniards, because it is difficult to extricate one's self from its hold when the dress is caught; as one part is cleared another will be entangled. A yellow and brown fly-catcher builds its nest in these bushes, and generally places it alongside that of a banded wasp, so that with the prickles and the wasps it is well guarded.

"I witnessed, however, the death of one of the birds from the very means it had chosen for the protection of its young. Darting hurriedly out of its domed nest as we were passing, it was 


\section{Animal Partnerships \\ \&}

caught just under its bill by one of the curved, hook-like thorns, and in trying to extricate itself got further entangled. Its fluttering disturbed the wasps, who flew down upon it and in less than a minute stung it to death."

Other tropical birds seek the society of stinging ants for the same reason. Thus in Nicaragua many birds hang their nests from the extremities of the branches of the bull's-horn thorn; and a safer place could hardly be chosen, as with the sharp thorns and the stinging ants that inhabit them no mammal would dare to attempt the ascent of the tree.

Stinging ants are not the only insects whose protection birds secure by building near their nests, for a small Central American parrot breeds constantly on the plains in a hole made in the subterranean nests of the termites, or destructive "white ants," whose forays are so much dreaded. And a woodpecker of the Eastern Himalayas actually takes up its quarters inside of the habitation of an ant.

There is a kind of ant there which constructs a globular nest of a soft felt-like material, a 


\section{The Wit of the Wild \\ \&}

foot or more in diameter, suspended upon a branch and involving many twigs and leaves. Into this gray-brown mass the woodpecker bores a hole and then scoops out a chamber large enough for its nesting purposes, while the ants continue to occupy the remainder of the globe.

The most perfect and mutually beneficial partnerships in animal life, however, are those formed between birds and certain large grazing mammals, for each member is of service to the other. We have a daily example before us in our own country in the way that the cow-blackbirds go afield with the cattle and stay close to them as they feed. The profit to the birds is in snapping up the insects the cows flush from the grass as they move about, and the cattle like the little friends who perch so confidingly upon their backs, for they not only catch or dislodge troublesome flies, but pull out of the skin any parasites which may have lodged there.

'All countries have something like this to show. In Spain jackdaws follow the herds of pigs, and in Central America a certain plover is protected by the people because so serviceable to 


\section{Animal Partnerships \\ \&}

the cattle; while a certain plover of Egypt has been considered the friend and ally of the crocodile ever since Pliny's time.

It is in Africa, indeed, that the most prominent examples of this kind of partnership are seen. To none is the arrangement more important than to the rhinoceros, an animal stupid, short-sighted, and easily approached from any direction that does not carry a warning scent to its sensitive nostrils. But he feeds and sleeps in peace under the watchful care of a flock of starlings, who flutter about him or run up and down his rough back picking off the various ticks and grubs that would keep him itching or perhaps work real harm, and which to them are excellent morsels. Moreover, they are supernaturally keen as watchmen, as hunters well know, for many a fine rhino has got away because the rhinoceros-birds made haste to wake their patron, by pecking at his head and screaming in his dull ears until he took warning.

This same starling, or one like it, may also be seen sitting in rows on the heads and horns of buffaloes when feeding or ruminating, and 


\section{The Wit of the Wild}

\&

they warn these animals in the same way. The buffaloes of Central Africa are also guarded and attended in a similar manner by a beautiful little white egret, whose snowy plumage and statuesque pose look very quaint perched upon some shaggy old bull of the forest. Zebras are looked after by a helmet-shrike, and "the tiny threecollared plover," according to Bryden, "is called the "sea-cow bird' from its fondness for the hippopotamus, or sea-cow, with which it is often found associating." Hunters are well aware of these facts, for they have lost many an expected trophy or sorely needed dinner on account of them, and you cannot persuade them that the association is anything less than a real and intelligent partnership.

The most extraordinary of these mutually protective arrangements, however, is that between Cook's petrel and the tuatara lizard of New Zealand. This petrel, or " titi," breeds on rocky islets on the New Zealand coast and deposits a single egg at the interior end of a tortuous burrow several feet long, dug by the birds themselves. 


\section{Animal Partnerships \\ \&}

" On some of the islands," says Buller, "there exists a very remarkable lizard-the tuatara of the Maoris. Wherever the tuatara and burrowing petrel coexist there appears to be a perfect understanding between them, and they share the same habitation. When, as often happens, the terminal chamber of the burrow has two chambers, one is occupied by the bird and the other by the reptile-usually cheek by jowl."

The curious part of the story follows. Ordinarily the lizard is timid and does its best to escape; but here, whenever any one attempts to meddle with the bird on its nest the lizard immediately comes to the rescue, attacking the hands with exceeding ferocity and biting fiercely. So real and constant is this defense that collectors of the petrel's eggs are obliged to dispose of their faithful guardian before they can get at the nest. What reward the tuatara exacts or receives for this friendly service, beyond the shelter it enjoys, is not known. 


\section{The Bird that Whips Poor Will}

\section{\&}

W

HEN the sun has disappeared so long that only ruddy lines athwart the west remain to show where it has set, and a darkness as of velvet pours slowly into the hollows of the landscape, then suddenly there springs from the warm gloom of the hillside the cry of the whip-poor-will, loud, vivid and challenging. At first you may hear only a single uncertain call, repeated now here, now there; but soon the bird settles upon a place that suits him and begins his song in earnest, chanting steadily while the darkness deepens.

This eerie cry is a characteristic note of summer throughout the eastern United States. Wintering silent and secluded in the warm regions bordering upon the Gulf of Mexico, the shy bird gladly turns homeward from its exile as spring returns, and steals north, always by short night-journeys, as fast as insect-life

$$
\rightarrow 02 \text { to }
$$




\section{The Bird that Whips Poor Will}

\section{\&}

awakes and furnishes him subsistence. There is a tradition in Virginia that it arrives there whenever "corn is up"; but it is not usually heard in New York before May-day. Even then only the wilder places may listen, for the whippoor-will avoids the town and lends his society to farmer and woodsman alone. He hunts along lanes and country roads, where he is so fond of rolling about in the dust that the Mexicans call birds of this sort "road-blockers"; and after the farmer and his "hands" have gone indoors for the night, searches the orchard and dooryard, and summons his rivals to vocal contests there, but he has no mind for displaying himself by daylight.

None of our birds, perhaps, is so truly and exclusively nocturnal as this one. Owls, bitterns and even night-hawks, are often seen abroad in daylight, but never the whip-poor-will, nor its big Southern cousin, the chuck-will's-widow, even in the cloudiest weather. To find them, in the daytime, you must go into dense woods or some swampy thicket, where their days are passed watchful of a nest or soundly sleeping 


\section{The Wit of the Wild \\ \&}

until the return of twilight shall make it safe for them to venture out in search of food and pleasure.

Of a creature leading such a life as this, so strangely at variance with all our notions of bird-nature, one might expect something unusual in appearance and structure.

Taking the bird in your hand you are struck by the general resemblance in its form to a chimney-swift, and are not surprised to find it classified in the books next to the swift family. Here are the same muscular shoulders supporting long, pointed wings, the short, stout, wedgeshaped tail, capable of wide expansion, and having great power in guiding and checking flight, - as is needful in a bird whose activity in the air must surpass that of a moth or grasshopper, - the short legs and weak feet, and the minute beak terminating a vast mouth. Its legs are feathered to the toes, perhaps to prevent ants and other minute biting insects crawling up upon them during its daylight sleep; and the middle toe is greatly prolonged and furnished, on the undersides of its claw, with " pectina- 


\section{The Bird that Whips Poor Will}

\section{\&}

tions" forming a regular comb, useful for cleaning its long whiskers, and for keeping its head free from the parasites to which a daysleeping bird must be especially exposed.

The head of the whip-poor-will is, indeed, its most peculiar part. Large, round, fluffy and bewhiskered, its owl-like aspect (more striking in some of the eared tropical species than in this one) is enhanced by the great brown eyes that bespeak the nocturnal habitant, and by the diminutive, almost hidden beak, arched above and upcurved at the point below, forming a pair of pincers well able to hold a struggling moth. These pointed, horny lips are only the extremity, however, of a mouth and throat so capacious that when they are opened it seems as though the head were split in halves; and it is to this great mouth, quite big enough to take in the teat of a goat, coupled with their habit of leaping about the cattle in the evening in pursuit of the insects they stir up, that these birds owe their ancient name caprimulgus, - a goatmilker; but night-jar is a better term. Springing from the upper lip is an array of stiff 


\section{The Wit of the Wild}

bristles, some of which reach out far beyond the tip of the bill and then curve inward, aiding in the capture of the bird's agile prey by entangling their wings as if in a trap.

Another resemblance to the owls (and incidentally to the nocturnal moths as compared with the diurnal butterflies) is found in the fluffy softness and neutral tints of the plumage.

Complete noiselessness is highly important to the success of nocturnal creatures, whether hunting or hiding; and even more so is invisibility of hue. Gay colors need daylight for their display, as well as for easy recognition, and would not only be wasted upon a nightranging animal, but might become a source of positive danger during the day, exposing the wearer to discovery and an assault that he could neither avoid nor repel. The night-jars are utterly defenseless birds. The Southern chuckwill's-widow is said to pretend to prodigious powers of harm, ruffling its feathers and hissing like a snake when disturbed from its rest in a hollow log; but in reality it can make no defense, and like the others must rely wholly upon being 


\section{The Bird that Whips Poor Will}

\section{\&}

overlooked or managing to dart out of danger. Nature has therefore done the best she could for these weaklings by making them inconspicuous.

Our whip-poor-will, indeed, is an excellent example of the adaptation of animal colors to customary surroundings. Its plumage presents to the eye at a little distance a brownish neutral tint blended of ochres, grays, browns and blacks, apportioned in an exquisite pattern to each silky feather; the only break is made by a rather obscure crescent of white upon the breast, which, through the overlapping of feathers and dim reflections from the ground, quite disappears when the bird is sitting in its usual squatting fashion. In fact, when the whip-poor-will is at rest in the flickering gray-green light of the woods, the whole of it practically disappears,becomes as unnoticeable as any fallen leaf or chip, - and the bird understands very well how to avail itself of such protection, by crouching low and keeping utterly still. Species that live on open plains are gifted with almost supernatural abilities in this direction. 


\section{The Wit of the Wild}

\&

The whip-poor-will's singular habit of sitting lengthwise, instead of crosswise, as other birds do, upon a log or bough, arises, I believe, from this instinct for concealment rather than from any inability to perch transversely. In the activity of the night, or when solicitous about a discovered nest, they will often stand athwart a bough or fence-rail like any other bird. That they ordinarily sit lengthwise during their diurnal siesta $I$ believe is due to a feeling that they are safer that way-a matter we can explain by observing that in that position they simulate a knot or the stub of a broken limb, and thus escape eyes that would at once mark a crosswise attitude. I am surprised that no one has called attention to this before, since something similar is highly characteristic of certain tropical species. Mr. W. Saville Kent, who had a close acquaintance with the Australian night-jar, called "morepork," tells usand shows photographs to prove it-that whenever it is alarmed, as, for instance, by the appearance of a hawk in the sky, "this bird will at once straighten itself up stiffly, and, with its of 168 so 


\section{The Bird that Whips Poor Will \\ \&}

mottled feathers closely pressed to its body, assume so perfect a resemblance to the branch upon which it is seated, that, even at a short distance, it is almost impossible to recognize it. - . People have actually placed their hand on the bird, when seated on a rail or log fence, before being conscious of its presence. . . It will thus remain stiff and motionless, and not attempt to fly away, until forcibly removed." Again, Mr. Frank M. Chapman has lately described how a Mexican species will behave, under fear, in almost the same way, assuming an attitude so thin, gray and rigid, with closely appressed feathers and beak pointing to the sky, that no naturalist need feel ashamed of mistaking the bird for an upright stub or splinter. It is true that the legs and feet of our whippoor-will are poorly adapted to firm grasping, but this may be more or less the effect rather than the cause of the practice referred to.

As nature cannot afford to make this mantle of invisibility so perfect that the birds shall not be able to find each other, she has provided them with a private badge or signal, whereby 


\section{The Wit of the Wild}

\section{8}

they may easily recognize one another in the air-the only time (except as between mated couples) when there is any need for such recognition marks. This badge is a large patch of white bordering the tail. It is near the end on each side, and slides out of sight underneath the central quills when the bird is quiet, but is conspicuously displayed when the tail is fanned out in flight. This is also a badge of the male sex, for in the hens these outer tail-feathers are cream-colored and not nearly so plain to viewanother indication that among birds the female chooses her mate rather than is chosen; it is consequently more important that she should be able to recognize and follow him than that he should always know her.

In all birds the spring molt is followed by the brightest plumage of the year. Tennyson's " livelier iris comes upon the burnished dove," is good ornithology. In many, moreover, temporary nuptial finery is put on in the way of novel and sometimes gorgeous colors and frills, that disappear after the breeding-season. Our goldfinch and bobolink are familiar local ex- 


\section{The Bird that Whips Poor Will}

\section{\&}

amples, and more striking ones may be found in the tropics. Even some of the somber seabirds, like the shag, assume a gay top-knot as an advertisement of their desire to marry; and, in short, it is a general rule that male birds add something attractive to their dress on the approach of the nesting-time.

Among nocturnal birds an accession of color would evidently be ineffective, and such nuptial ornaments as they indulge in must attract by form rather than by color. Nowhere is this more curiously shown than by tropical nightjars. In one South American group the wings of the males have three of the flight-feathers enormously elongated, so that they trail or flutter like streamers as the bird flies; and in another the two outer tail-feathers are more than twice the length of the bird's body, and bend inward at the tips antil their white points nearly meet. It is a singular sight to watch one of these "lyre-tails" hawking after insects, the long plumes opening and shutting like a pair of flexible calipers.

Central Africa shows even more remarkable 


\section{The Wit of the Wild}

\section{\&}

ornaments distinguishing the male night-jars and putting them among the curiosities of birdlife. The one best known is the standard-wing (Cosmetornis), where one of the outer feathers in each wing is several times the length of the others, and undulates behind the bird in its evening flight like a ghostly streamer, for it is the only white feather in the wing. Another has similarly elongated quills, but these are bare almost to the end, where a brown, paddle-shaped vane appears, barred with black; and Schweinfurth tell us that as the bird " chases the mice it looks as though it had a couple of satellites in attendance." The Arabs call it Father Four-wings. It appears only after dark, and scientific observers are so few in its country that we don't know much about the bird; but Prof. Alfred Newton gives in his great "Dictionary of Birds" a note and picture which show it roosting in the daytime on the ground with its wing-quills, some twenty inches long, held perfectly upright, so that the little terminal vanes tremble unnoticeable among the heads of the grasses. 


\section{The Bird that Whips Poor Will \\ $\&$}

Considering the fact that neither our North American, the European nor the Asiatic nightjars sport such appendages in the breeding-season or at any other time, the reason for their existence in these scattered tropical species is a problem which I, at least, cannot solve. It would seem as though such extras, however much enjoyed and proudly flourished by their owners, would be more trouble and risk than they were worth. Professor Poulton has elaborated a theory that long tails and fluttering appendages such as these serve a purpose of safety by tempting a pursuer to seize upon and thereby lose the body of his quarry, because they will easily break off or pull out; but why should nature make elaborate preparations to have a creature almost caught, (and then maimed) in order to insure its safety? On the other hand it is observable that these lengthened wing-quills do retard and interfere with flight (though long tail-feathers do not seem to do so), and hence are really disadvantageous. This may be one of nature's errors, tending to the extinction rather than to the prosperity 


\section{The Wit of the Wild \\ \&}

of the species. Development is not invariably upward.

Our whip-poor-wills announce their arrival in May by their familiar call, but some days pass before they get into full song, and even then they are much influenced by weather, keeping silent when it is gloomy, even for several days in succession, while on warm moonlit nights they are vociferous from dusk to dawn. Ordinarily, a couple of hours after dark and another hour or two before dawn give them time enough to express themselves. They are remarkably regular as to the time (referred to the setting of the sun) of commencing and quitting, and they like to resort to the same spot night after night. One will often make a beginning and then seem to stop and try it over again, like a person practicing a new tune; but these interruptions really mean so many leaps into the air, with perhaps frantic dodges and a somersault or two, for the snatching and devouring of some lusty insect that objects to the process. They never regularly sweep through the upper air as does the nighthawk, but seek their food near the ground 


\section{The Bird that Whips Poor Will \\ \&}

by leaping after it in short, erratic flights. They have a way of balancing themselves near a tree-trunk or barn-wall, picking ants and other small provender off the bark; and even hunt for worms and beetles on the ground, turning over the leaves to root them out. It is not until their first hunger has been assuaged that one hears that long, steady chanting for which the bird is distinguished, and which, as a sustained effort, is perhaps unequaled elsewhere.

The singer is fond of perching upon a stone, -rocky hillsides are favorite resorts, - or upon a stump, fence-post or shed-roof. I do not believe he ever sings in the air, though low murmurings may be heard as he flits past, for he seems to need a solid fulcrum under his feet for the great physical eff ort his utterance seems to cost. He begins by a sharp, liquid churp! like the plumping of a big drop into a cistern, then swings into his loud monotonous recitative.

To my ear he does not say " whip-poor-will" at all, yet it is not easy to write down an exact interpretation of the notes. The first syllable is a clear whistle strongly accented and end- 


\section{The Wit of the Wild \\ \&}

ing in a hard $t$-not in a palatal. The last part is a forcible whéyo-that sound, as of a switch lashed through the air, which gives us our word whip. The emphasis is very great. All the breath the bird has seems driven into the final syllable-tongue-lashing, of the most literal and vindictive sort, which can be heard half a mile. Nuttall, often so felicitous in portraying bird-music, writes it 'whip-'whip-poor will, 'whip-perí will, noting with truth that the repetitions tend to fall into pairs; and he adds that to the ears of the aboriginal Delaware its call was wecowális, but thought that " probably some favorite phrase or interpretation." Others tell us that the Seminoles of Florida imitate it by wac-co-lár, and the Chippewas of Minnesota by grwen-go-zoi-á. In "The Auk" (viii, 35) Mr. S. P. Cheney has given a whole page of musical notation to illustrate variations perceptible to the trained ear.

Considerable individuality is perceptible in their voices, and they are likely to improvise unusual endings, or to break off with comical abruptness, as though suddenly seized with dis- 


\section{The Bird that Whips Poor Will}

\section{\&}

gust at the performance. The sharply whistled whit-to-whéyo is rarely given singly, though one sometimes hears whit, whit, whit, repeated soft and low, or a sharp chirk, or liquid gurglings that seem outpourings of a heart full of happiness.

But this is chatter and woman-talk, for when the head of the family really sings he makes the woods ring with a surprising clamor. Launching his voice at full strength, he strikes at once into a gait of about sixty repetitions to the minute, and keeps at it as regularly as a machine for several minutes. It is an ordinary feat for him to "whip poor Will" with two or three hundred strokes in unbroken succession, and sometimes the flagellation goes further, my wife noting in one instance, when one summer we made a business of counting the beats, no less than 831 unbroken repetitions, lasting nearly fifteen minutes and then stopping suddenly in full voice. Such a performance seems objectless, except as a show of endurance, but as such it is truly wonderful.

Another very queer thing about this song is 


\section{The Wit of the Wild}

\section{\&}

the click to be noted between each rohit-towhéyo, audible several rods away under favorable conditions; but this follows the final syllable with such suddenness as to seem coincident with it, and so exactly resembles a tapping together of dry sticks that it is almost impossible to convince yourself that it is a vocal utterance.

To hear a single whip-poor-will calling alone is uncommon. Usually a second or several birds begin their evensong about the same time, and then vie with one another with angry energy. When they are many, the racket raised soon becomes tiresome; but where there are only two their rivalry is amusing. Each shouts at the top of his voice, as if trying to drown his rival, and failing that he increases his speed until each bird is working at a breathless rate, but bound to outlast the other. The result is, that after a few moments they coincide in time, when, as neither can any longer hear the other, each stops, believing itself the victor.

While these braggart cocks are denouncing "poor Will" throughout the summer evenings, 


\section{The Bird that Whips Poor Will}

\section{\&}

and of ten waking us, to our disgust, long before dawn by their "damnable iteration," the patient hens are secretly pursuing the joys and labor of maternity.

Like all its tribe, except the aberrant group Podargus of New Zealand, our whip-poorwill lays its eggs upon the ground in the woods, making no nest whatever and seeking no particular concealment. It chooses an open, dryish spot, perhaps with the feeling that such places are likely to be overlooked by the animals ever prowling through the thickets in search of eggs or fledglings. Professor Newton asserts that the British night-jar, or fernowl, which is closely like its American cousin in habits, returns year after year to the same spot to breed, and many indications suggest that our whip-poor-wills have the same constancy.

The eggs are always two in number, rather large for the bird and of equal thickness at both ends ; and are cream-colored, prettily speckled with lilac and red. As if aware that they may be easily seen, the mother broods very closely during daylight. Watching you with 


\section{The Wit of the Wild}

\section{\&}

intent alarm, she will quietly let you come quite close, trusting to the invisible rusty hue of her back; but at your next step her fears overcome her prudence and she is off like a fleeing shadow, never fluttering away, pretending to be wingbroken, as does the nighthawk when similarly disturbed. This, very likely, is the first intimation you have of her presence; and then, as your eye alights upon her treasures and you stoop down to examine them, you hear the soft cluckings of the distressed mother, and perhaps see her flitting in timid circles around you as if tethered by a cord. Audubon declares that these birds will move their eggs to a safe place if they are handled by any one; and describes how he himself saw each of a pair of chuck-will'swidows pick up an egg in its mouth and fly away with it. He also says that they will carry the fledglings out of danger in the same way; and Wilson tells how, after he had been sketching a downy young whip-poor-will, on going back for a forgotten pencil, he found that his little model had disappeared, although unable to travel. There is no reason to discredit these 


\section{The Bird that Whips Poor Will \\ \&}

stories, although recent confirmation of them is lacking.

The fledglings are not born naked, as are those of most small birds, but clothed with a yellowish down so near the color of the dead leaves on which they lie as almost to defy search, -and they remain absolutely quiet.

Now this rigidity and silence, as a measure of safety in these infant birds, must be purely instinctive, for they are characteristic of the very youngest, who could not have learned the trick from their parents. Why does not the terror that causes the mother to rush away communicate itself to them as an impulse to flutter away also? And why do not they answer her anxious cluckings? Instead of this, they lie close and dumb, and when at last you find one and take it up it will squat in the palm of your hand as motionless as if paralyzed. The fledglings of tree-nesting birds do not behave in that way: they must be well-grown before they will show either fear or caution at your approach, and, in spite of the warnings of their agonized mother, will cry just as loudly when 


\section{The Wit of the Wild \\ \&}

a shrike, or a weasel, or a bird's-nesting boy appears at their door, as when their own parents come there. This noisy loquacity, in fact, brings destruction to them, as often as the young whip-poor-wills escape it by their sensible silence, notwithstanding their more exposed situation.

The young are fed at first mainly upon halfdigested food disgorged by the parents, and later upon soft worms until able to receive and digest beetles and winged insects. The parents are brave in their defense, but this must be mainly by "bluffing," for no bird is so poorly provided with weapons as this. "The chuckwill's-widow," Audubon tells us, "manifests a strong antipathy toward all snakes, no matter how harmless they may be. Although these birds cannot in any way injure the snakes, they alight near them on all occasions, and try to frighten them away by opening their prodigious mouth and emitting a strong, hissing murmur."

It would by no means be surprising if a bird like this should share with the owl and the bat a superstitious regard from those ignorant 


\section{The Bird that Whips Poor Will}

\&

of nature and fond of mysteries. There still lingers among us the imported tradition of its milking the cattle, which began, perhaps, among the goat herds on Mt. Olympus; but that mistake is almost world-wide, existing even in the heart of the Sudan. Wilson hints at quaint beliefs among the farmers of his day, but, unfortunately for lovers of folk-lore, he fails to recite them; an earlier naturalist of Philadelphia, Dr. Benjamin S. Barton, records, however, that " it is an old observation in Pennsylvania, that when the whip-poor-will arrives it is time to go barefooted."

Down in Virginia they say that the white spots on the wings of its cousin, the nighthawk, are silver dollars.

As for the bodings and dire omens so frequently referred to in ornithological writings of the sentimental sort, a somewhat extensive search has shown only that in northern New England (where the bird is rare) it is believed that a whip-poor-will singing beneath your bedroom window presages your early death. In more southerly regions, where the bird comes 


\section{The Wit of the Wild}

\&

every night close to the house, no such a superstition can survive, of course. I was more surprised, however, at not being able to find that this bird has any part in the folk-lore of weather signs.

Indian folk-lore is almost equally barren. The Carolina Indians told Catsby that they had never heard whip-poor-wills until after one of the tribe's early battles with Europeans, and hence considered them the souls of their ancestors killed in that battle; but this has the earmarks of a "yarn." Dr. Barton, writing in Philadelphia in 1799, remarks:

"Some of our Indians believe that this bird is a messenger sent to call their attention to the planting of the ground. Accordingly, upon the arrival of the whip-poor-will, they say to one another, ' The wee-co-lis is come: it is plantingtime'; and, while the bird is uttering the sound of whip-poor-will, or wee-co-lis, they will repeat the word hackibeck, which is 'plant the ground.'"

Modern Iroquois indulge the pretty fancy that the moccasin-flowers (cypripediums) are the whip-poor-will's shoes. 


\section{The Bird that Whips Poor Will}

\section{\&}

The Utes call the bird a god of the night; and say that it made the moon by magic transformation of a frog; and among the Sioux and Omahas a pretty custom leads a person whose attention is attracted to the calling of the whip-poor-wills at night to go out and question them, by asking "No?" Should the birds stop at once it is a sign that the questioner must die soon; but if the birds continue singing he will continue to live for a long time. 


\section{Birds of a Feather}

\section{\&}

$\mathrm{N}$

OTHING is more characteristic of autumn than the assembling of birds in companies, sometimes of vast extent. Each consists, usually, of birds of a single sort only, whence the proverb as to "birds of a feather."

This familiar fact illustrates one trait of birds that is seldom recognized, and it is very pleasing-the sociability which arises from a sympathetic nature.

It is true that various advantages may come from the flocking of some birds during migrations, and that necessity may account for other assemblages, yet in most cases, at any rate among the smaller songsters, birds seem to delight in the company of their kind and in association with other kinds simply for the sake of it.

That hordes of water-birds throng about $\rightarrow$ of 186 


\section{Birds of a Feather}

\section{\&}

certain cliffy coasts of islets, or within the recesses of some swamps, is due mainly to the fact that places suitable for their nesting and feeding are limited, and local crowding results; but this will not explain gregarious breeding habits in others, such as the wild pigeon and various swallows and seed-eaters.

Mutual self-protection is certainly not now the reason for the flocking, whatever may have been the case in the remote past (when perhaps the tendency thus arose under different conditions), for the danger from enemies to birds in this country, at least, is increased by herding rather than diminished. We are driven back, then, to the simple and natural reason that birds enjoy one another's society.

This fraternal, sympathetic, one might say affectionate, disposition is apparent in all their relations with one another-that is, within their own tribe.

Most birds show much conjugal attachment, and from the courting time in spring until the young are well grown most mates remain together. Some of the large birds of prey seem 


\section{The Wit of the Wild \\ \&}

to mate for life, owing probably to scarcity of possible partners; but there is no satisfactory evidence of this custom among any of the little birds, though it has often been asserted of the dove.

It is the female, nevertheless, who directs domestic affairs, as well she may, for she does most of the housework. She it is who selects the site, and is the architect of the home, deftly weaving the materials and fitting them within to her comfort. Every nest bears upon its interior the impress of the faithful breast that molded its form with loving anticipation, and brooded there with patient anxiety.

At the same time the male is in most cases a worthy assistant, especially among those birds which dig out holes. If he wears a brilliant plumage, however, the male is likely to keep out of sight, for his gaudy presence would often be a dangerous advertisement of the home, which both parents are so anxious to conceal.

Hence, while the wife works the husband sits within her hearing and sings, partly to her, no doubt, but mainly because he feels too jolly to 


\section{Birds of a Feather \\ \&}

keep quiet. At night he roosts near her while she sleeps on the nest, or, in rare cases, he builds a nest-like hut for himself - one of the very few instances of an animal taking pains to erect a shelter.

The baya sparrow, so called, a weaver-bird of India, furnishes the best example of these cock nests, but each pair of our own marsh wrens construct several nests (hollow basketballs among the reeds), only one of which is occupied for brooding, while the others form sleeping quarters for the males or are not used at all. The nest of the baya, however, is double, one chamber being occupied by the nest proper, with its eggs and brooding female, while the male roosts in the other part.

Our small woodpeckers, too, are likely to dig two holes, in one of which the father of the family takes shelter when he pleases.

While the eggs are being laid or incubated the male holds aloof still more cautiously, only darting in morning and evening for an hour or two (regularly timed) after his mate begins to sit, in order that she may steal away for food 


\section{The Wit of the Wild \\ \&}

or exercise; yet he is rarely out of earshot, so that she may not only be cheered and comforted by his singing, but may summon him by a cry of alarm when she needs help; and it is a poor sort of bird indeed that will not instantly rush to defend its home.

In this respect birds are far superior to the four-footed animals, according to our ideas of morality, for almost all of them will boldly and distinctly fight in defense of nests and family, regardless of peril to themselves, whereas few if any male mammals will do so.

Among birds, in truth, we first find a sense of fatherhood and husbandhood, for when their wives are busy in nest-building, and later are brooding upon the eggs, their mates bring them something to eat and when the young are fledglings the father as well as the mother labors to provide for them the enormous quantity of food which they require. This helpfulness varies with different species, however, some being much more attentive and maintaining their family relations much longer than others.

Most of the smaller birds of this country 


\section{Birds of a Feather}

\section{\&}

choose to nest alone, scattering far and wide over their breeding range, so that each pair may choose a hiding place and have little competition for food in its own neighborhood. They are jealous of infringement of these rights of reservation, but rarely quarrel with neighbors of other species.

Thus a single old orchard tree will often harbor half a dozen families, nesting on its branches or in some broken cranny, or within its chambered trunk. Even the peppery oriole will permit that, and the fish-hawk lets blackbirds place their nests, as sub-tenants, among the sticks that form the wall of his huge castle. Among such solitary home-makers are species most gregarious in the fall, such as our blackbirds and bobolinks.

On the other hand, a few land birds that seem to have no advantageous reason for doing so carry their love of society into their domestic life and crowd their nests close together, sometimes forming clusters which can be compared only with the packed tenement-houses of human cities. The most conspicuous instance of this 


\section{The Wit of the Wild \\ \&}

among American birds is (or was, for it is now almost extinct) the wild pigeon, which once so loaded the trees with its nests and perching pairs that limbs would break under their weight, and this over spaces of forest several miles square. To a greater or less degree this is the habit of pigeons elsewhere, and doubtless it is owing to this companionability in its temperament that we have been able to domesticate many varieties of this kind.

Another tribe highly sociable in its nesting as well as in its migratory life is that of the swallows, which, in all parts of the world, not only nestle in companies, but gather into immense wandering bands as soon as their family duties are over.

Our eave-swallows, for example, whose bulbshaped nests of mud are set in rows beneath the eaves of country barns, in primitive days attached these adobe chambers in compact masses against the faces of cliffs and claybanks. A similar fondness for crowding characterizes all sorts of swallows; and that it implies a peculiar companionability of temper is indicated by the 


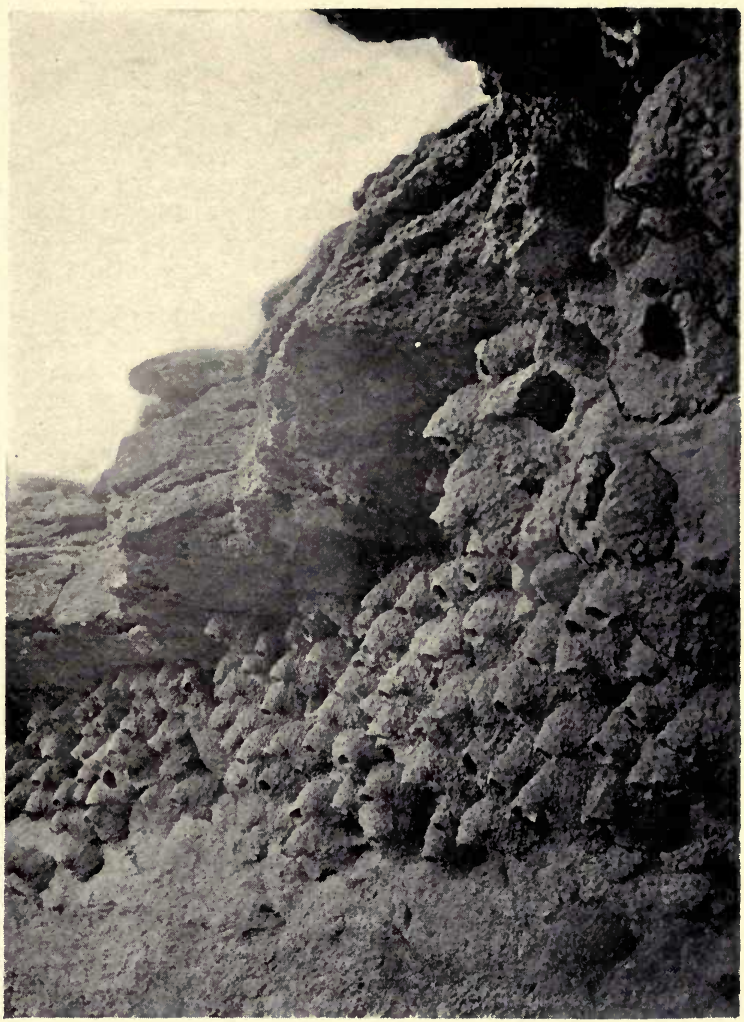

J. W. James, Phot.

Nests of Wild Eave, or Cliff, Swallows

They are massed beneath overhanging ledges on the face of a cliff in Arizona 



\section{Birds of a Feather \\ \&}

fact that in all countries swallows have been quick to attach themselves to mankind and to make their homes about buildings.

Such bird-towns or collections of nests may be repeated for many years, and yet they will be nothing more than so many separate homes near together. There is no united communityalmost the only advantage of the crowd being that some are always on the lookout and ready to alarm the rest when danger threatens.

The same is true of the vast rookeries of herons, pelicans, cormorants and many sorts of sea-fowl, which cover remote cliffs, beaches and islands, with as many nests or eggs as the room permits. They are gregarious and friendly, but not helpful to one another except in a very limited, accidental way.

Little more can be said of the weaver-birds. These small finches are numerous in South and Central Africa, and of several sorts. All build large nests of grass, lodged among the treebranches, and several are inclined to colonize, placing half a dozen or so structures in a single tree-top. One species goes a little further and 


\section{The Wit of the Wild}

\&

joins its nests together into a huge mass, in which each pair has a chamber where birds and eggs seem safe from all enemies except climbing-snakes; and these composite structures are repaired and used year after year, no doubt by the descendants of the original builders.

Still more advanced, however, are the colonies of another species, the "social" weaver, which literally dwell under one roof. These birds erect mushroom-shaped structures among the branches of a tree, the top of which is a conical covering of grass, all lying smooth and lengthwise from peak to eaves-a regular thatched roof. In the thickness of this roof are as many nesting chambers as there are pairs in the flock - perhaps fifty or more. The entrances are narrow holes on the under side, and they are almost entirely inaccessible, while the thick roof not only protects the sitting mothers, but shelters the whole flock from blazing sun and torrential rains.

An attack upon it is resented by the combined forces of the colony, and any damage done to this huge structure (which may be five or six 


\section{Birds of a Feather}

\&

feet in diameter and visible for a mile) is immediately repaired, for these fine apartmenthouses are occupied year after year. This is probably the nearest approach among birds to a real community and a truly social life, and it is the highest manifestation of their graceful disposition toward companionability. 


\section{Do Animals "Commit Suicide"?}

A STUDY OF BRUTE IIMITATIONS

\section{\&}

T $\mathrm{N}$ that fascinating book, "Wild Animals I Have Known," no chapter is more allur1 ing in its mixture of plain fact and fanciful interpretation than the one which chronicles the doings of the Springfield fox and its dramatic end. This story, which purports to be that of the real field-life of an actual American red fox, is made vivid by the human perceptions and sentiments attributed to the animal as its own, among which is a perfect comprehension of death. This fox, it appears, knew thoroughly the use and efficacy of poison. That such an animal may learn and teach its young to detect by smell the taint of poison in a piece of meat, and so refuse to eat the morsel on the broad ground that it is unsafe, or on the narrower ground that it has something to do with 


\section{Do Animals " Commit Suicide"?}

\section{\&}

the enemy, man, all of whose works are to be suspected, is easy of belief. "Vix knew right well," says Mr. Seton, " what poisoned bait was; she passed them by or treated them with contempt, but one she dropped down the hole of an old enemy, a skunk, who was never afterward seen."

One must wish this naturalist would substantiate by more particulars this revengeful murder by indirect means, which seems to me to imply more, in several directions, than we have been able hitherto to grant to the intelligence of even a fox; yet this is easy of acceptance beside the further deeds of this prodigy, after its mate had been shot and its home ravaged by men and dogs. Three of its cubs are killed and a fourth is made captive and chained in the farmer's yard. Night after night, urged by mother-love, old Vixen comes to feed her imprisoned bairn, and to try by every strength and device of tooth and nail and mind to get it free. At last she becomes convinced that no effort of hers can loosen the chain, and the next night she turns to her last resort:

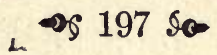




\section{The Wit of the Wild}

\section{\&}

"Like a shadow she came, and in a moment was gone, and Tip seized on something dropped, and crunched and chewed with relish what she brought. But even as he ate, a knife-like pang shot through, and a scream of pain escaped him. Then there was a momentary struggle and the little fox was dead.

"The mother's love was strong in Vix, but a higher thought was stronger. She knew right well the poison's power, . . now at last when she must choose for him a wretched prisoner's life or sudden death, she quenched the mother in her breast and freed him by the one remaining door."

After that Vixen is no longer seen in the neighborhood,-_" gone, maybe, deliberately," says the author, "from the scene of a sorrowful life, as many a wildwood mother has gone, by the means that she herself had used to free her young one-the last of all her brood."

Now, here is an assertion, as of observed facts ; first, of two premeditated murders by a brute animal, one from motives of prudence and revenge, and another from motives of the highest moral import; and, second, an implication, 


\section{Do Animals "Commit Suicide"? \\ \&}

amounting almost to an assertion, of conscious suicide. If it were no more than a bit of pathetic fancy it would be worth notice only as evidence of a popular notion, but it is woven into what is declared to be a true story of the conduct of life by an actual fox, and thus takes its place as an assertion of history.

But do animals ever kill one another, except by accident, in anger or as prey? And, do animals ever commit suicide?

What is suicide? Literally, and taking the word merely as it stands, nothing more than self-killing; but the customary and now only proper definition involves the idea of intentional, voluntary self-destruction, and this implies on the part of the being so acting an understanding of the circumstances of life and death, - at least of the difference between them.

The literature of dog-stories - if one may use the expression-abounds in anecdotes of pets, or of canine servants of the hunter and shepherd, which have grieved themselves into a speedy decline and death by exhaustion due to refusal of food, on the graves of their dead 


\section{The Wit of the Wild \\ \&}

masters; which have refused to leave them in moments of great peril, as in a shipwreck, and so have perished; or which in some other way have sacrificed their lives for their friends or at least with them. All these incidents, however, only illustrate that remarkable dependence and sense of duty which distinguish the dog-an inheritance from innumerable generations of trained ancestors taught to be "faithful unto death."

Something of the same disposition is occasionally shown in the horse, which stands next to the dog in long association with man. The sense of dependence upon and affection for a master is so exceedingly strong in most dogs, that when one of them is suddenly deprived of companionship it is no wonder it places itself as near as possible to where its benefactor has been laid, and waits for his reappearance, fearing to leave the place even for a moment, lest it shall miss his return. This very attitude proves that it does not apprehend the finality of its master's condition. At last exhaustion, and the nervous depression resulting from grief,

$$
\text { - } 200 \text { so }
$$




\section{Do Animals " Commit Suicide"?}

\section{६}

mysterious dread and disappointment, causes mortal illness, - but there is no evidence the dog foresees or intends a fatal result. In the other class of cases, the idea of remaining with a master, danger or no danger, or of defending him, as if it were itself attacked, is so strong in a good dog as to overcome timidity and prudence.

Something different from this is needed as evidence of intentional suicide; and when the incidents alleged to furnish such further evidence are examined, they are always, so far as has come to my knowledge, found wanting. Here, for an instance, is one published in Notes and Queries during 1898. An English gentleman, who owned a small terrier, was obliged to go to the Continent for his health, and after a few weeks died. When the news of his death came the dog seemed to understand what had happened, "and shared the grief of the family to such an overwhelming extent that one day it went to an upper window and jumped out, killing itself in a very distressing way." Any one considering this narrative a moment may see 


\section{The Wit of the Wild}

\section{\&}

how many assumptions it contains, and especially how supposititious is the conclusion. There is no evidence that it was not an accident. Terriers often fall from windows and sometimes jump from them. Only a short time ago a dog sprang from a lofty window-sill in New York in an attempt to catch a bird; it either did not know, or more probably forgot, the peril of the leap. My own dog, the first time it was taken in a boat upon a lake, stood on the prow of the boat a while and then deliberately sprang overboard, where it was immensely surprised and alarmed to find itself struggling in deep water: all the water it knew about previously was very shallow.

Had not the circumstances of both these lastmentioned cases been known, and especially had they been associated with deaths in the families, or something else remarkable, they might well have been adduced as examples of conscious selfdestruction.

A correspondent of The Field some time ago gave a long account of how a terrier between repeated attacks of "fits," first dashed himself 


\section{Do Animals " Commit Suicide"? \\ \&}

off a high wall and then ran into the sea, where, after a few half-hearted strokes, it turned on its back and drowned. The observer declares his belief that the animal deliberately put itself out of its miseries, but most of us cannot but attribute the acts to temporary insanity. It is difficult to separate sympathy, romance and tradition from facts and cool judgment, in such cases. It has been an ancient belief, for example, coming down from the middle ages, that a scorpion put within a circle of fire will sting itself and die as soon as it perceives that there is no escape; but not only do not modern scorpions turn to the felo de se as a release from expected pain, but no scorpion could sting itself to death if it tried.

Perhaps the influence of these old fancies lingered in the mind of Mr. Seton when in another chapter of the same book he suggests suicide as the final proud and praiseworthy act of a wild stallion, which for years had baffled all pursuers. At last, however, an organized effort for the capture of the "pacing mustang" was at the point of success: 


\section{The Wit of the Wild \\ \&}

"The man rejoiced, but the mustang gathered his remaining strength for one more desperate dash. Up, up the grassy slope from the trail he went, defied the swinging, slashing rope, and the gunshot fired in air, in vain attempt to turn his frenzied course. Up, up and on, above the sheerest cliff he dashed, then sprang away into the vacant air, down-down-two hundred feet to fall, and landed upon the rocks below, a lifeless wreck-but free."

All equine animals are subject to insane panic, when they lose all self-control and may rush blindly to accidental destruction; but this author, who claims to be relating actual facts, doesn't mean us to understand this incident in that way. I should like to hear his explanation of how this black mustang, or how Vixen, the fox-mother, had arrived at the knowledge that death meant freedom, and was preferable to the halter? What experience had either of captivity? No such condition exists in nature: what reason had they to foresee, much less dread it? Upon what data could they create a mental picture (granting imaginative ability) calculated to alarm them so profoundly? 


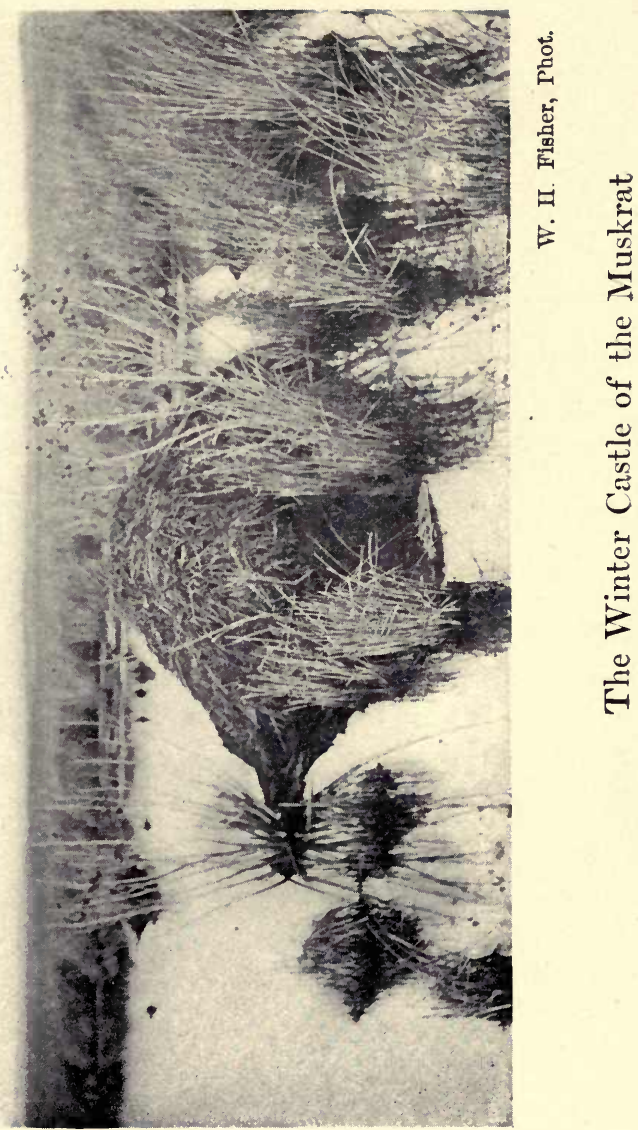





\section{Do Animals " Commit Suicide"? \\ \&}

If horses or foxes comprehend so much as that, why do not thousands of over-worked, halffed, cruelly abused domestic animals, and many a starving or tortured wild one, commit suicide every day? Why do not fur-bearing animals caught in traps kill themselves at once instead of dying by inches, or merely gnawing off the fixed foot, - an act, in my opinion, due to an effort to relieve the dreadful pain, and not to a deliberate method of release. Either they do not know enough, or else their sense of moral responsibility is superior to that of thousands of their masters.

So enamored is Mr. Seton of this conceit of suicide among wild creatures that he resorts to it again as the climax of his "Biography of a Grizzly,"-a childish performance, at best, for a man who has shown such literary ability. He disposes of his hero, supposed to be a typical bear, living an average life, when old age and rheumatism make him feel ill and unfit, by making him go to a certain narrow valley which he (the bear) knows of, and which is strewn with the remains of animals that have perished in the 


\section{The Wit of the Wild \\ \&}

fumes of a stream of noxious gas that flows out of a hole in the rocks. The disgusting odors of Death Gulch " had a message for him," and Bruin meditates that it is far to Yellowstone Park, where he may end his days in peace under the protection of Uncle Sam's hospitalitythough how could a grizzly have learned that? Moreover, as the sage animal reflects, "What's the use?"

"Here in this little garden was all he sought; here were peace and painless sleep. He knew it; for his nose, his never-erring nose, said 'Here! here! now!' He paused a moment at the gate, and as he stood the wind-borne fumes began their subtle work. . . A rush of his ancient courage surged in the grizzly's rugged breast. He turned aside into the little gulch. The deadly vapors entered in, filled his huge chest, and tingled in his vast, heroic limbs, as he calmly lay down on the rocky, herbless floor, and gently went to sleep."

I can leave to others the literary question whether it is good to wind up a story, alleged to be of facts, with a purely imaginative dé- 


\section{Do Animals " Commit Suicide"?}

\section{\&}

nouement. My contention now is that animals do not know anything whatever about life and death as contrasted or correlative conditions; and can have no idea that life may be ended, or that death is an alternative state which may be arrived at by fatal means.

Young beasts do not recognize death when they see it manifested in a lifeless body-though the highest apes seem to have some glimmering of the truth-but will linger about a mother that has been shot and try to awaken her attention. Older animals usually recognize a dead body as dead, but the state seems to mean to them only a mysterious disability,-incapacity for resistance and readiness to be eaten at leisure. In the case of carnivores, the last is probably the most vivid impression, and many of them will devour almost at once a partner, or even mate or off spring, killed by their side, when not themselves too much alarmed to take advantage of the lucky provision. Hunters constantly meet with instances of this "cannibalism."

I have watched with interest the behavior of my dogs toward dead animals. They would as 207 so 


\section{The Wit of the Wild}

\section{\&}

approach them cautiously, uncertain whether there were not some trick of play or hostile ruse in the immobility, until they could smell the cold form, then would turn away with an expression of wonder and disgust, but no further interest. Hunting animals have learned that in order to feed upon their prey they must reduce it to complete disability: it is the submission-not the death - of the creature which they seek when they strike. Such was the idea in the minds of the retrievers, made much of by Romanes, which kill one of two wounded ducks when they find it impracticable to retrieve both birds alive, as they are expected to do. The dog uses its natural dog sense in completing the disablement of an unmanageable thing, in order to accomplish that part of its mission which it feels of the highest importance, viz.: To get the game ashore, somehow. The retriever does not seek the death of the duck, per se, but merely its instantaneous acquiescence in his plan.

How could a dog or any other brute creature know of death apart from its outward aspects of disability and subsequent dissolution? What 


\section{Do Animals " Commit Suicide"?}

\section{\&}

more, really, do we know about it, aside from our belief in Divine Revelation, or in the deductions of metaphysics? What data have the brutes for supposing that it gives "surcease of sorrow," or offers any refuge from distress, or even that such a change can be obtained by one's own act?

To comprehend the fact, not to say the nature, of death, one must comprehend the fact of self-life, and all that we know of the range of brute intelligence leads us to deny its ability to postulate self-existence. No experience can avail brutes in judging the eff ect of being lifeless, and every case of death seen must seem to the onlookers (if they "sense" it at all) utter ruin - something to be strenuously avoided. This is the natural physical view of death which must prevail throughout all nature, or life would come to an end. Everything in the natural world shapes itself and tends toward the preservation, in order to insure the propagation, of life. All feral instincts face that way, and to impartial laws and processes, with which individuals have nothing to do, is alone intrusted 


\section{The Wit of the Wild \&}

the duty of keeping within bounds the degree of multiplication.

Self-sacrifice is a supernatural, human idea, utterly at variance with all nature not human, and subversive of its prime reason and motive for existing. Nothing could be more illogical, or wicked, in the brute world, than the possibility of intentional self-destruction. Dogs and other animals may sometimes recklessly expose their lives to fatal peril, or, influenced by some nervous stress or extreme emotion, fall ill and die, or do blindly some fatal act; but we may be sure that no animal ever truly commits suicide, because no animal has any conception that it is possible to do so. 


\section{A Turn-Coat of the Woods}

\section{\&}

T TEREWITH is reproduced a most excellent photograph from life of a little creature which almost everyone knows by name and by the sound of its voice, but which is rarely seen. It is the "tree-toad"-really not a toad at all, despite its lumpish and warty appearance, but a true frog that spends most of its time in the trees instead of on the ground or in the water, as do others of the family.

To enable these small frogs to make their homes on the smooth and shaking branches of trees, they are given special means of holding tightly to an upright surface. The extended fingers of the forefoot are not connected by webs, as are those of the water-frogs, nor terminated by suckers, like those of some climbing lizards, but are thickened at the ends into knobs, the under sides of which form cushions always moist with a sticky perspiration enabling the 


\section{The Wit of the Wild \\ \&}

frog to take a firm grasp of whatever he touches.

This is really a very interesting bit of mechanism. The holding-power seems really due to the fact that all air is pressed out from beneath the pad of the toe, rather than to either suction (certainly not exerted) or the stickiness of the secretion, although the latter helps. The matter was experimentally studied by the German naturalist Schuberg, who found that he could support more than the weight of one of these frogs from a bit of glass merely moistened and pressed against another glass surface. The glass sides of a case or fernery, in which these frogs are kept captive, will soon be smeared with their finger-marks.

In addition to this, the lower half of the abdomen (where the skin is thick and porous) also exudes a sticky liquid, so that when the animal sits pressed against the bark of a tree-trunk, or any other upright surface, he is really glued there, and thus supports his weight more easily than if he clung with his hands and feet alone. All the same, he likes to sit in a comfortable 


\section{A Turn-Coat of the Woods \\ \&}

crotch, where he can rest his back, like other folks.

Lurking in such a place, he becomes an ogre to minute creeping and flying bugs of all sorts, who never notice his gray or green coat until out darts a spoon-like tongue, and they are caught and dragged into his stomach. The little ones feed especially on the destructive plant-lice (aphides), and thus do a service of great and particular value to the owners of orchards, and recommend themselves as most excellent assistants to be kept in a conservatory or hothouse.

The instrument with which Mr. Tree-toad catches insect food is his tongue, and it is an extraordinary one of its kind. It is almost as round as a ball - a regular lump of a tongueis not attached at the hinder end and capable of being stretched out forward, but beneath its front end, so that it is rolled over and its hinder end is thrown out of the mouth, something as a boy throws a return-ball attached to a rubber cord. It is coated with sticky saliva, and so any small object it hits adheres to it and is 


\section{The Wit of the Wild \\ \&}

brought back into the mouth, which has a few teeth in the upper jaw to help crush the food if necessary to do so before swallowing it.

If these little frogs would only keep quiet they would rarely be found except by accident, but they are the noisiest of their kind-in fact, one of the noisiest creatures in the woods, especially in summer, when nature generally grows quiet. The skin of the throat is as elastic as a rubber ball; and gulping down a great quantity of air, the hyla will distend his throat until it looks like a small balloon, and then let the air escape through his vocal pipe in a shrill trill that is surprisingly loud and sustained for so small an animal, and can be heard a surprising distance. He never seems to consider that his shouting will betray his position, but will keep at it while you stand close to him and can watch every trembling movement of the inflated throat.

This loud and not unmusical trill is one of the earliest of spring sounds, though not so early as the peeping of the little yellow, or Pickering's, tree-frog, which opens the frog chorus as soon as the ice has gone out of the swamps, 


\section{A Turn-Coat of the Woods}

\section{ริ}

and sometimes before; and it outlasts the clamor of all the other frogs and toads, which grow quiet as the hot, dry days of early summer come on, while our hyla sings away until autumn. It is at night, however, that he is noisiest, for it is then he is most awake and busy, especially when it is wet. His skin, despite its thick and rough appearance, is exceedingly sensitive to changes in the atmosphere, and he is a fairly trustworthy prophet of rain. It is said that the German peasants sometimes keep them in captivity, so as to know when it will be safe to go to picnics; at any rate, let a damp, rainy day come in July or August, and the air is at once filled with the "croaks" of their loquacious race, whether in rejoicing or distress it is hard to say - the former, I guess. It is an old saying that tree-frogs crawl up to the branches of trees before a change in the weather.

In early spring the noise is made mainly by the males calling to the females to come down with them to the water-side. As soon as the warm days of late March or early April arouse these, as well as other frogs, from dormancy, 


\section{The Wit of the Wild}

\&

their first thought is of egg-laying - that prime duty of all wild creatures. For this purpose they, like other frogs, must go to the water; and in April (or perhaps later in northerly latitudes) they troop from the woods down to the swamps, ponds and muddy pools in order to deposit their eggs under water. Swimming or creeping out a little way from shore, they attach their eggs singly or in little clusters (not in masses of jelly, like the big frogs) to a blade of grass or some other support in shallow water and leave them to be hatched by the warmth of the sun.

This happens usually inside of two days, when the cream-colored tadpoles, a quarter of an inch long, struggle out of the egg coatings and cling to the grass stems by means of a temporary sucker-like appendage near the mouth, steadily gaining in strength, and hoping no big beetle or other dreadful ogre will catch them before they grow able to swim. This ability comes speedily with the perfection of the tail, for at first they have no limbs, and breathe through external tufted gills like a mud-puppy. 


\section{A Turn-Coat of the Woods}

\section{६}

In a week or so, however, the gills disappear, and a few days later the hind limbs begin to grow, progressing until even the feet are perfect by the time the tadpole is a month old. Another month must elapse, however, before the fore-arms have pushed out from the skin and been perfected, by which time the tail is shortened and has lost its leaf-like shape, and the hind feet have begun to do a part of the work of swimming. The plumpness shrinks to a more frog-like form, and early in July each tiny froglet, dragging a mere remnant of tail, begins to try what he can do with his feet on shore, and soon finds himself able to jump about and catch flies like an old hand. Then he hops away to the woods, climbs a tree or fence-post, and is received into hyla society.

The family to which this frog belongs (the Hylida) is a numerous one, and has a remarkable distribution, a fact which is commented upon by Dr. Hans Gadow, as follows:

"To say that this family is cosmopolitan, with the exception of the African region, is 


\section{The Wit of the Wild}

\section{\&}

literally true, but very misleading. There are in all about one hundred and fifty species, and of these, one hundred are Notogxan [i. $e$., belong to the Southern Hemisphere], one-half of the whole number, or seventy-five, being Neotropical [South American]; twenty-three are Central American, seven Antillean, and about eighteen are found in North America. One species, Hyla arborea, extends over nearly the whole Palæarctic region [Europe, Asia], and two closely allied forms occur in Northern India and Southern China. Consequently, with the exception of three closely allied species, the Hylidæ are either American or Australian. We conclude that their original home was Notogæa, and that they have spread northwards through Central and into North America. The enormous moist and steamy forests of South America naturally suggest themselves as a paradise for tree-frogs, and it is in this country, especially in the Andesian and the adjoining Central American subregions, that the greatest diversity of generic and specific forms have been produced. It is all the more remarkable that similar forest-regions, like those of Borneo and other Malay Islands, are absolutely devoid of Hylidæ. . . The various Hylidæ resort to all kinds of modes of rearing their 


\section{A Turn-Coat of the Woods}

\section{६}

broods. Most of them lay many eggs, up to one thousand, in the water, not coherent in strings, but in clumps; others lay only a few, attach them to various parts of the body, or, as in the genus Nototrema, the female receives them in a dorsal-pouch."

Of our North American species, the one we are talking about is the most widespread, occurring all over the country east of the dry plains, though becoming rare north of the Great Lakes. It is among the largest, too, being about one and one-third inches long, when fully grown. Its name in classification is Hyla versicolor, or the changeable hyla, in reference to its power of assuming, upon all its upper surface, the color of what it sits upon. This power is limited, however. If the animal were placed upon a scarlet or gilded or bright blue surface, it would not take those brilliant hues, because in nature it never chooses or is called upon to rest against colors so gay as these; but it will change all the way from dark green to nearly white, or to deep gray or reddish brown, according as it finds itself among green vegetation, or on an 


\section{The Wit of the Wild}

\section{\&}

old lichen-covered fence-rail, a moldering log or variously colored barks. The one here photographed was clinging to a birch tree, and the likeness of color in the illustration is not the mere sameness of printer's ink, but is a real similarity.

How is this change of color made? The process has been carefully studied by Biedermann in the case of the European tree-frog, and his conclusions apply to the American species as well. Gadow summarizes the explanation of the mechanism as follows:

"If we examine the green skin of the common tree-frog, Hyla arborea, under a low-power and direct light, we see a mosaic of green, polygonal areas, separated by dark lines and interrupted by the openings of the skin-glands. Seen from below, the skin appears black. Under a stronger power the black layer is seen to be composed of anastomosing and ramified black pigment-cells. When the light shines through the skin appears yellow. The epidermis itself is quite colorless. The mosaic-layer is composed of polygonal interference-cells, each of which consists of a basal half which is granular 


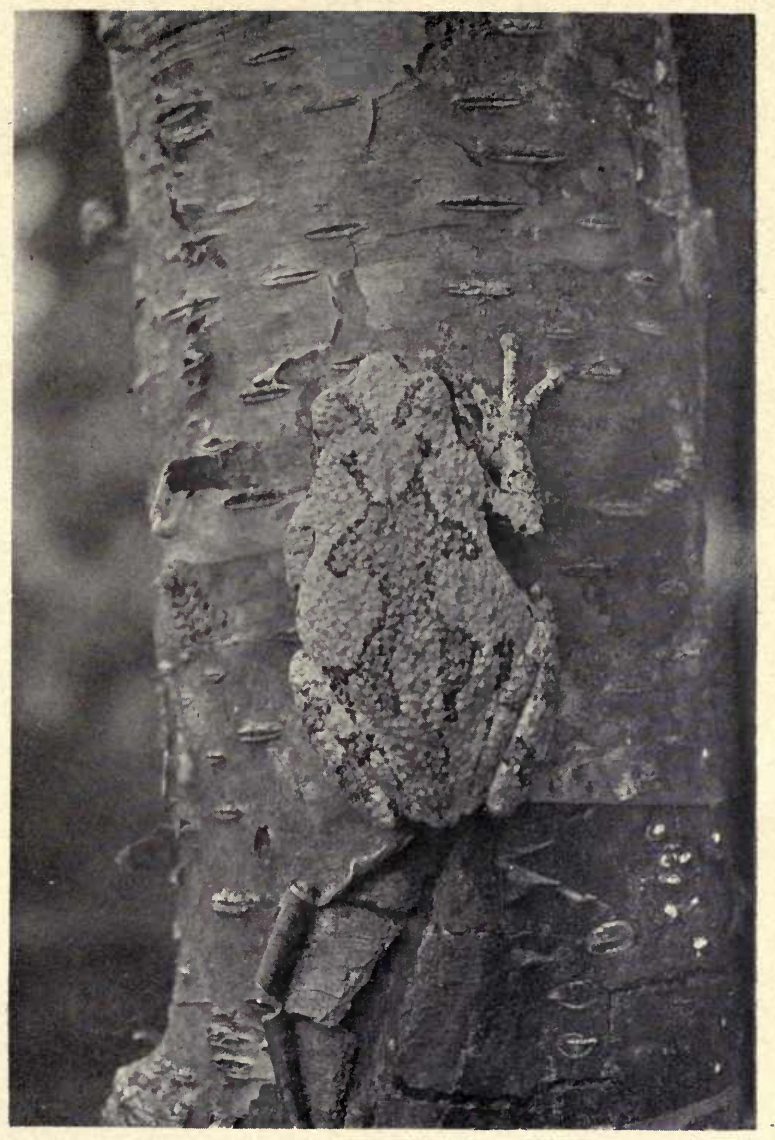

C. Lown, Phot.

\section{The Changeable Tree-frog}





\section{A Turn-Coat of the Woods}

\&

and colorless, while the upper half is made up of yellow drops. Sometimes the tree-frog appears blackish, and if then the black pigmentcells are induced to contract, for instance by warming the frog, it appears silver-gray; in this case the pigment in the yellow drops is no longer diffuse, but is concentrated into a round lump lodged between the interstices of the granular portions; the black pigment-cells are likewise balled together. These black chromatophores send out numerous fine branches, which occasionally stretch between and around the polygonal cells. When each of these is quite surrounded and covered by the black processes, the frog appears black. On the other hand, when the black pigment-cells withdraw their processes, shrink up, and, so to speak, retire, then the light which passes through the yellow drops is, by interference, broken into green.

"Stoppage of the circulation of the blood in the skin causes the black chromatophores to contract. Carbon dioxide paralyzes them and causes them to dilate. This is direct influence without the action of nerves. But stimulation of the nerve-centers makes the skin turn pale. Low temperature causes expansion, high temperature contraction, of the chromatophores. Hence hibernating frogs are much darker than 


\section{The Wit of the Wild}

\section{\&}

they are in summer. Frogs kept in dry moss, or such as have escaped into the room and dry up, turn pale, regardless of light or darkness, probably owing to a central, reflex, nervestimulus.

"Tree-frogs turn green as a result of the contact with leaves. Dark frogs will turn green when put into an absolutely dark vessel in which there are leaves. This is reflex action, and blinded specimens do the same. The principal centers of the nerves which control the chromatophores lie in the corpora bigemina and in the optic thalami of the brain. When these centers are destroyed the frog no longer changes color when put upon leaves, but if a nerve, for instance the sciatic, be stimulated, the corresponding portion of the body, in this case the leg, turns green. Rough surfaces cause a sensation which makes the frog turn dark. . . Biedermann concludes that the ' chromatic function of frogs in general depends chiefly upon the sensory impressions received from the skin, while that of fishes depends upon the eye.'

"All this sounds very well, but the observations and experiments are such as are usual in physiological laboratories, and frogs, when observed in their native haunts, or even when kept 


\section{A Turn-Coat of the Woods}

\section{ริ}

under proper conditions, do not always behave as the physiologist thinks they should. There is no doubt that in many cases the changes of color are not voluntary, but reflex actions. It is quite conceivable that the sensation of sitting on a rough surface starts a whole train of processes: roughness means bark, bark is brown, change into brown; but one and the same treefrog does not always assume the color of the bark when it rests, or even sleeps, upon such a piece. He will, if it suits him, remain grassgreen upon a yellow stone, or on a white windowframe. I purposely describe such conditions, changes, coincidences and discrepancies, in various species, notably in Hyla arborea, H. corulea, Rana temporaria, Bufo viridis, to show that in many cases the creature knows what it is about, and that the eye plays a very important part in the decision of what color is to be produced. The sensory impression received through the skin of the belly is the same, no matter if the board be painted white, black, or green, and how does it then come to pass that the frog adjusts its color to a nicety to the general hue or tone of its surroundings?"

Whether or not the little animal makes this change knowingly, sometimes doing it almost 


\section{The Wit of the Wild}

\section{\&}

instantaneously and sometimes gradually, or whether he cannot avoid the alteration of his coat if he wishes to, it serves to make him almost invisible to his enemies, such as birds and snakes, who may easily overlook what seems nothing but a knot or loose scale of bark. This power of hiding is, indeed, his only protection, for he has no weapons of defense, and much less agility in escaping than have many of his relatives. It answers the purpose so well, however, that it is not surprising to find tree-frogs exceedingly numerous in all parts of the country, serving everywhere to keep down the hordes of insects that dwell among the foliage and on the bark of trees and bushes, which always threaten to increase beyond control.

In the autumn, when the nights begin to grow chill, the leaves fade and fall, and the short life of the insect world comes to an end, these little frogs grow quiet, and, descending from their perches to the ground, seek a snug, warm berth in which to take their long winter sleep. Some creep beneath the drifting dead leaves, and squirm their bodies, tail foremost, as deeply into 


\section{A Turn-Coat of the Woods}

\section{\&}

the loose loam of the woods or garden as they well can, where their eyes close in a drowsiness which so fills their whole bodies that life practically stops until the sun of spring revives it. Others work their way into the dusty decay of hollow trees and rotten stumps, where they also rest secure from storm and trouble, unless some hungry mink or skunk may dig them out.

These frogs form interesting pets in a fernery, where they will sometimes become so tame that they may be let out and trusted to come back; and they pay for their care by devouring many minute, but noxious, insects. 


\section{The Biggest Bird's-Nest and its Maker}

\section{\&}

THE mere question: What bird builds the biggest nest? would be an idle query did 1 it not include various other interesting facts and considerations. One might reasonably argue that the bigger the bird the bigger the nest, and in a general way this is so,-an eagle is, of course, obliged to make a more capacious receptacle in which to bestow its eggs and rear its young than is a wren. But in a more particular way the rule does not hold. Birds of similar size vary greatly in the amount of nesting materials they gather, and in the accommodations generally which they seem to require. Thus, to recur to our house-wren, though it is one of the most diminutive of birds, it heaps up a mass of twigs often three times as large as the neat, compact home of, say, the cedar-bird, whose body is three times bigger. Our western 


\section{The Biggest Bird's-Nest}

\&

magpie is little larger than a jay, but its domed castle of thorny twigs would fill a bushel-basket. Then, too, the very largest of all birds, the ostriches, make no nest at all, in any proper sense of the word. The huge extinct ratite birds of Madagascar and New Zealand (relatives of the ostrich) laid eggs much larger even than those of the moa, that of the epiornis reaching thirteen inches in length. One can imagine the relatively vast capacity of the bed required for them; but such beds were probably nothing more than basin-like hollows scraped in the sand or among the dead leaves carpeting the forest.

For similar reasons we ought not to include the heaps of decaying vegetation thrown up by the mound-turkeys of Australia and neighboring islands, some of which are six to ten feet in height and ten to fifteen feet in diameter. These hillocks of weeds, grass and leaves, are tossed together by the birds by scratching backward, and have a crater-like form at the top in which the numerous eggs are deeply buried in layers and left to be incubated by the heat of the sun 


\section{The Wit of the Wild \\ \&}

and of the fermentation of the vegetation. But in most cases several females work at and use the same mound, which rules them out of our consideration.

In absolute bigness, the result of the labor of a single pair, the foremost place (with one exception, which I shall consider in detail presently) belongs to the great birds of prey. Gould long ago expressed the opinion, in his "Birds of Australia," that "the largest nest known was that of the Australian sea-eagle," which he said contained " materials enough to fill a small cart." The same expression was used by Wilson, the father of American ornithology, in describing the eyries of fish-hawks along the coast of southern New Jersey. "I ascended," he says, "to several of these nests that had been built in from year to year, and found them constructed as follows: Externally, large sticks, from an inch to an inch and a half in diameter, and two or three feet in length, piled to the height of four or five feet, and from two to three feet in breadth; these were intermixed with cornstalks, seaweed, pieces of wet 


\section{The Biggest Bird's-Nest \\ \&}

turf in large quantities, mullein-stalks, and lined with dry sea-grass; the whole forming a mass very observable at half a mile's distance, and large enough to fill a cart, and be no inconsiderable load for a horse."

Still more bulky nests are still to be seen on certain protected islands off the eastern end of Long Island, if recent reports have not been exaggerated.

These nests of the American ospreys, and of the foreign sea-eagles, are, however, subject to a serious discount in our present view, since they are occupied continuously, and are the accumulations of many years; and while decay and the winter winds cause the loss annually of a certain proportion, so much new material is added in the way of repairs each year as to steadily increase the total mass. Our whiteheaded eagle is a closely related form, and its nests sometimes become truly gigantic through continual occupancy for many years. Such ancestral eyries are known in many parts of the country. One on the lake shore near Cleveland, Ohio, had been the home of successive pairs of 


\section{The Wit of the Wild \\ \&}

eagles for a century until recently, when the old tree fell.

The biggest regular nest made by a single pair of birds, and used only one season, is undoubtedly that of a small African wader, named by the early ornithologists umbrette (Scopus umbretta), but popularly known in South Africa as hammer-kop (hammer-head). It is allied to the storks, yet is sufficiently distinct to be set apart in a family by itself, and is about the size of a raven, but in shape and carriage suggests an overgrown sandpiper. In color it is umber brown, handsomely glossed with purplish; the bill black and feet brown. The head exhibits a thick crest of feathers, which may be erected uprightly, but is usually carried horizontally, balancing the long conical beak, and so giving a hammer-like outline to the head in the side view.

It is found in Madagascar and throughout most of Africa, wherever wooded districts prevail; and its food consists of fish, reptiles, frogs, worms, snails, and insects, captured alive in shallow water or found dead. Sir Harry Johns- 


\section{The Biggest Bird's-Nest \\ \&}

ton mentions that in Nyassaland these storks are welcome scavengers; and as their flesh is utterly uneatable, the birds are not much molested there, and therefore are far from shy in most places.

In South Africa, according to Layard, they are regarded by the natives as the agents of witches, and hence are rarely injured for fear of evil consequences. It is an interesting coincidence, pointing to cunning wisdom on the part of ancient ruler-priests, that in tropical lands nearly all the sacred animals are those which are of practical service locally, as scavengers, or destroyers of noxious snakes and crocodiles, or in some other way; and at the same time have no particular worth as food. It was a far-seeing sagacity which prompted the thought that the best way to preserve such animals, and so enjoy the benefit of their work, was to throw around them the shield of reverence, which in the savage is superstitious fear. In the present case, nevertheless, the association with witchcraft may simply arise from the weird appearance and cries of the birds, as they circle in the dusk above the swamps, where they are likely to remain hid by 


\section{The Wit of the Wild}

\section{s}

day; and from their curious dancing in pairs or in threes in lonely spots.

The British settlers in Africa find them rather easy to tame and amusing as pets, except for their harsh, quacking cries. They indulge an odd habit of prancing around one another when feeding, and occasionally at other times, as is the way of many of the waders. Layard gives an extended description of these antics.

Their time for activity is mainly in the cool of the evening and early morning. "The quaint-looking umbers," remarks Schweinfurth, author of "The Heart of Africa," "which are generally seen sitting solitary by the shady swamps in the woods, were here [Dyoor, Sudan] marshaled along the banks in flocks of twelve or fifteen; these birds, with their ponderous crested heads pensively drooping in the noontide heat, seemed in their ' somber weeds' rather to belong to the dreary wastes of the chilly North than to the smiling grass-plains of the upper Nile."

Now none of these features of structure or habit would suggest that anything unusual in 


\section{The Biggest Bird's-Nest}

\section{\&}

the nest-building was to be expected; yet in fact the architecture of this bird is very curious indeed. Instead of a scanty platform of loosely entangled sticks on some limb or bush-top, as is the custom of most storks and ibises, the hammer-head constructs an astonishingly large and elaborate home for its family. It is a huge composition of weeds, sticks, etc., placed in a fork of a large, low tree, or sometimes in a rocky cleft, and one examined by Layard measured three yards long by a yard and a half across. It is ordinarily flat on top, as figured by Holub and Penzeln in their great work on SouthAfrican birds, and its roof will easily bear a man's weight.

This massive bird's nest is entered by a hole in one side, only large enough to admit the owner, and contains three chambers, connected by small openings, and lined with grass and weed-stems mixed with clay. "The sleeping chamber occupies the highest portion of the nest, in order to be safe from floods, and in it, upon a bed of water-plants, are laid the white eggs, which are from three to five in number, 


\section{The Wit of the Wild}

\section{\&}

and are incubated by each parent in turn. The middle chamber serves for the young when they are too big for the inner one, while the hall is used as a lookout station."

Mr. Layard also says that the birds are also fond of embellishing their substantial home with anything bright or glittering which they may pick up, as brass buttons, bits of pottery, bleached bones and the like. This reminds one of the similar fancy of the Australian bower-birds, which likewise construct very elaborate homes. Where animals spend much time and labor in their architecture, they evidently feel a much more profound and lasting interest in their habitations than do those which form merely hasty and temporary breeding-places.

It is an entertaining matter for speculation, why this bird should diverge so far from its relatives in its home-making habits, and choose to produce a nest which is a regular castle in comparison with the ordinary type. We cannot see that the hammer-head is exposed to any greater present dangers than are its cousins, or that it gains much or anything from its 


\section{The Biggest Bird's-Nest \\ ६}

superior comforts and defenses-that is, the umbrettes do not seem to increase faster than do the other African waders. On the contrary, they are nowhere numerous, and perhaps as a race are on the decline.

The explanation of the problem should no doubt be sought in the early history of the species. This bird is of very ancient lineage, its anatomy, which has been specially investigated by Beddard, showing many generalized features, indicating that its history goes back farther than that of any other species or group of its kind. In short, it is the nearest remaining representative of an ancestral stock from which herons, storks and ibises have branched off and become severally differentiated. The conservatism it has shown in organization may have been accompanied by an equal conservatism of mind; and so its peculiar modern nestbuilding is probably a traditional method descended from a time when it was needful to make so strong and warm a nest, and which has tenaciously been adhered to beyond a time when it ceased to be advantageous. 


\section{The Wit of the Wild}

\&

Thus, in our search for the biggest nest, we have also discovered one of the most ancient styles of architecture remaining among birds, and have hit upon an interesting underlying principle of natural history, - a curious parallel to the history of the opossum detailed in another chapter. 


\section{The Phœbe at Home}

\section{\&}

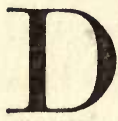

AY after day, in the spring, a certain small bird comes at intervals into the top of a half-dead tree near the house, and sits there by the half-hour. It is a demure little figure in blended olive-green and brown, with a large, dark head, and a tail narrowly edged with white. It bears itself soberly, like some dear old Quaker lady in plain rich silk, with touches of lace here and there, like the soft edging of foam that bedecks the summer sea. Sometimes there are two, and they sit very upright on the cleanest twig, as if they had been trained, as was the good dame I have suggested, in some prim, old-fashioned "seminary," which taught them that the backs of chairs were not for use by the young; and I hear them calling, sometimes insistently, sometimes carelessly, their name, tsweé-zee. That is the true pronuncia- 


\section{The Wit of the Wild}

\section{\&}

tion, as nearly as I can catch it, but my neighbors generally find that too hard, and call the bird phœbe. More extraordinary changes than that have taken place in names from a foreign language, as genealogists well know.

The family is of fly-catcher stock, and my friends belong to the pewee branch, being own cousins to the aristocratic wood-pewee, whose plaintive peé-ah-weé hints at decayed fortunes, and who holds himself aloof. There are various other relatives, such as the chebec of our gardens, the Acadian, the olive-sided, and other woodland sorts. All have the family trait of sitting very erect and waiting for Providence to send insects near enough to be seized by a quick dash-their eyesight being microscopically keen. I have read that the kingbird (another relative) has been seen to make a dash of more than one hundred feet in order to seize a minute insect near the observer's face. Though the phœbe may get much of its food in morsels too small for us to perceive, and we laugh at the sudden dash and somersault the act requires, and to hear the vicious snapping of the pincer- 


\section{The Phobe at Home}

\&

like beak as gnats are caught " on the fly," it sometimes stoops at larger food, even condescending now and then to pick up a wriggling caterpillar, or to engage in a contest with a moth half as big as itself.

The phobe is one of the earliest birds to return to us from its winter home, which may have been in Mexico or the West Indies, or perhaps not farther away than North Carolina. It is the latter, hardier ones, no doubt, that are boldest in following the retreating winter northward, so that we often hear their little song before the last snowstorm.

Now begins the most entertaining chapter of phœebe's history - that of its home-making and home-keeping. There is a sweetness of domesticity about the nesting and brooding of a bird that belongs to no other creature. The bees make good houses, and dwell in them and care for their offspring and for each other; and the affection for their young in the four-footed animals is often striking and courageous, but the suggestion of real home-life and happiness in the ways of our woodland birds in spring ap- 


\section{The Wit of the Wild \\ \&}

peals to the human heart almost beyond anything else in nature.

My friendly phoebe was the builder and owner of a nest made after the old prehistoric phobe fashion on the front of a well-shaded ledge nearby. No new-fangled notions for her! She was satisfied with the ways of her forefathers, and expected her children to abide by them. Her home, then, was founded upon a shelf hardly wide enough to hold it, above which an overhanging rock gave not only shelter from the weather but security against attack from above; and in addition it was shadowed and hidden by a mingled maple and shad-bush. The face of the rock was rough, and on many of its ledges and projections, where a trifle of soil had been borne by the winds or by trickling rainwater, moss had taken root, and, clinging with microscopic fingers, had spread into irregular patches. To make her home look like one of these had been the object of the little architect. No bigness nor ostentation and needless ornament formed a part of her plan. These might do for her cousins, the strong kingbirds, or her other cou- 


\section{The Phœbe at Home}

\&

sins, the wood-pewees, who play the fine lady in the forest. Her idea was the substantial, the inconspicuous, and the safe.

With this in view, Mme. Phœbe and her husband together, after much interesting investigation and colloquy, decided upon a good spot, and there the work of the husband seemed to end. Whether he is too indolent, or thinks it infra dig., or pleases himself with the notion that he will play soldier and defend the laborer, or whether he is simply not permitted by his spouse to meddle with this important matter, you may decide for yourself. At any rate, Mme. Phøebe seems to do all the work alone, but her mate entertains her now and then by a little song, which is scarcely more than a repetition of his name, as fast as he can chatter, for a minute or so at a time. The builder finds some spot where moss is growing, plucks it up by the roots, brings the sprays, with the mud clinging to their roots, and lays them in a circle upon the rock, where the material is patted down by her feet until its sticks. If the shelf is wide enough a complete circle is laid, and as more is laid and 


\section{The Wit of the Wild \\ \&}

patted down on top, a bowl is presently built; but generally she likes to set the structure in a corner, or against the wall, and then it becomes a half or three-quarters circle.

Several days are consumed in this operation, but not much work is done except in the morning, leaving the new material to dry during the afternoon. She works slowly and carefully, too, spending many minutes, at times, in trampling down the wet moss with her feet, pushing it with her breast to make the cavity of just the right size and fitness, and arranging and rearranging the sprays with her bill, delightedly loitering about her work like any other happy young home-maker. If not enough mud clings to the roots of the moss, she brings more, in pellets, and uses it as extra mortar. Finally, when she has erected the rim so high that it will conceal all of her body except head and tail (as she sits upon her eggs), she lines it with a bedding of horsehair, to lift the eggs above the chill and dampness of the adobe walls and base. Meanwhile the hardy moss, rooted in the nest, lives and keeps green and hangs down in tufts, 


\section{The Phœbe at Home \\ \&}

so that the resemblance of the nest to any of the many patches of naturally growing moss about it is nearly complete, and the architect's attempt at concealment by this likeness is entirely successful. It seems the more so when, as frequently happens, the bird avoids the use of any ledge, along which a mouse or weasel or snake might possibly creep, upon eggs intent, and plasters her dwelling, in the form of a heavy bracket, right upon the face of the rock, where it clings by the cohesive force of mud, mingled with the moss and other fibrous ingredients.

Thus far one might say that the phobe showed great intelligence, but it is worth while examining whether that is really a good word to use, if by "intelligence" is meant conscious adaptation of means to an end. It is probably safe to say that this method is a departure from the more ordinary tree-nesting habit practiced by its relatives rather than that it alone represents an original style from which all the rest have departed. It secures more safety by greater inaccessibility, at the expense of using much mud and also at the expense of far greater labor 


\section{The Wit of the Wild}

\section{\&}

than is required by the ordinary stick or grassbuilt home. Its resemblance to a patch of moss is an accidental result of the use of such materials, but the effect of this is so good that natural selection seems to have nearly perfected the tendency to the exclusive use of moss.

The mud, of course, is a mortar needed to hold the nest in place when it is bracketed against the face of a rock, which may be considered the typical situation, but it is rarely needed when the nest rests upon a ledge or other flat surface, as it often does; yet the birds seem rarely to spare themselves labor in that casethough now and then a nest will be found with very little mud and composed of miscellaneous materials.

Thus far I have been dealing only with the primitive style of nest, in the wilderness. But this bird has been one of the first to attach itself to mankind, as settlements advanced into the interior, and to make use of his structures. Its greatest anxiety, apparently, in choosing a nesting-site was to find one beneath a shelter, so that the rain should not dampen and chill the 


\section{The Phœbe at Home \\ \&}

mud, or perhaps dissolve it, and so ruin the nest completely. When men came to their locality. and began to build houses and sheds and bridges, the phøebes instantly perceived the advantage their roofs and covering afforded, and straightway began to occupy nesting-sites beneath them. Barns they seem rarely to have entered, perhaps because the pugnacious swallows always drove them away; but carriage-sheds, isolated and unf requented buildings, like boat-houses and sugar-camps, were and are quickly seized upon, and in many a rural house to-day a pair of phobes is a regular summer accompaniment in some corner beneath the porch-roof. Bridges they are especially fond of, finding in the stone abutments a semblance to their natural cliffs, with an admirable roof in the bridge floor; but they often choose to put the nest, even there, on the upper surface of a beam or girder, perhaps just beneath the planks of the rattling roadway. So constant and peculiar is this custom that in many parts of the country the bird is known as the "bridge pewee." Abandoned and broken down old houses, especially the stone ones so 


\section{The Wit of the Wild}

\section{\&}

common in the Hudson Valley, are almost always inhabited by the phoebe, too, and the basement or cellar seems to be preferred, no matter how dark. In such places they are not shy, and will let you make a close acquaintance with their life.

Now in this association with man, and in these improved situations, which have been occupied in the older districts by succeeding generations of phoebes for one or two hundred years, the birds seem to have changed their style of nestbuilding in only one particular, though they occasionally pick up civilized material, such as strings, tufts of wool, straws, etc.; the one particularly referred to is the now prevalent use of horsehair as lining, where they must have employed fine grass before horses came into the country. This novelty, however, is a disadvantage, for it causes the nests to become so overrun with vermin that it is said the young are sometimes worried to death by the excess of it. This would prevent the use of the nest for the second brood, which the early-breeding species almost always raises; but it frequently happens that a second nest is built upon the top of 


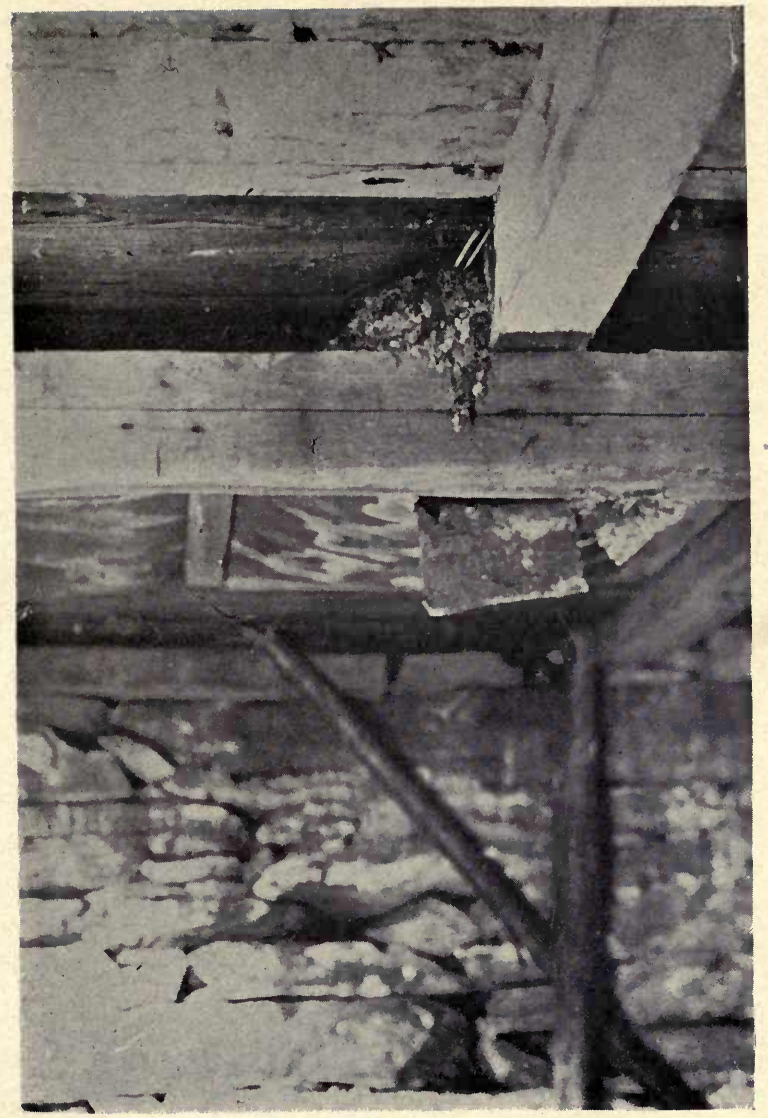

C. Lown, Phut.

\section{Phœebe's Nest}

This nest was on a beam in the basement of a half-ruined stone house ; and the white-edged tail of the brooding bird is seen over the edge of the mossy structure 



\section{The Phœbe at Home \\ \&}

the first, or close beside it. I once found six nests in a row, touching one another, on a protected ledge of rocks in a lonely part of West Virginia, some of which may have been for second broods, though most of them, no doubt, were the work of successive seasons.

But in general the heavy, laboriously built mud and fiber bowl or bracket will be found in the most concealed and well-covered situations, where a very slight open structure would have sufficed for all purposes, as well as in a completely exposed place, and the green coating of moss is maintained there, where it is of no protective service, as carefully as on the wild crags. Moreover, it often happens that in such circumstances the moss is worse than useless-it positively draws attention to the bird's home. A notable instance came under my observation last summer, when I found a beautiful example of the bracket-nest affixed to the white-plastered wall inside a ruined house in Ulster County, N. Y., and this year a new nest surmounted it. Here the green moss was the very opposite of protective-it attracted the eye instantly. This 


\section{The Wit of the Wild}

\section{\&}

illustrates one of the reasons why it is not fair to speak of the bird's " intelligence" in apparently concealing its cliff-built home by a coating of living moss.

Indeed, one wonders at the bird's stupidity sometimes as much as its cleverness. A marked characteristic, belonging, more or less, to all birds, is its love of locality, and enjoyment of placing its home as near as possible to the place it lived in the season before. A rural railway station of stone that I know has been resorted to for years by phœbes, presumably the same pair, who almost always build on a projecting stone about four inches below the crowning timber that supports the roof of the porch. Two years ago their nest was knocked down there by one of the bad boys who are the pest of all villages, and the birds hunted up a new site. They fixed upon a projection of the wall on the other side of the building, and a new nest was begun. This stone, however, was fully fourteen inches below the timber that had formerly limited the height of their nest, and the foolish birds, apparently thinking it needful to carry 


\section{The Phobe at Home \\ \&}

their work up to that familiar level, heaped up no less than fourteen inches of foundation before they made a cup and lined it for the eggs. Such facts as these, among many that are known to students, seem to be interesting as showing the traditional character and limitations of bird intelligence as applied to nestbuilding. 


\section{The Haymakers of the Snow Peaks}

\section{\&}

W

HEN one, in climbing almost any of the great mountains that stand, range behind range, between the plains and the Pacific coast, comes out above the woods upon the naked slopes and crags of the summit, he has reached a new world, and one whose attractiveness grows with longer acquaintance. One's first walk above timber-line, however, will be likely to set his curiosity on edge to account for innumerable keen, bleating cries, which seem to come now from the rocks beneath his feet, then from the wonderfully clear and silent air, or from near and far to the right and to the left.

Pausing in silence and looking intently about him, in an effort to solve the mystery, the explorer's eye will presently detect a movement, as if a shadow flitted across the scant sod, or a 


\section{The Haymakers of the Snow Peaks}

\section{\&}

piece of rock itself had moved; by and by, if alert to this suggestion, his eye will catch a glimpse of a small creature, so near the color of the stones, as to seem a part of them, and then of another and another, until, if one remain quiet, a score may come into sight. Gaining confidence they will begin scuttling about, sit up like tiny poodles, and squeak out their small yet wonderfully resonant cry, with outstretched necks and jerking heads like the barking of a toy dog. Let the rambler make a noise or motion, however, and every squeaker will disappear as if by magic, and every sound will cease.

These curious animals are pikas,-queer little degenerate hares which the miners and hunters happily call " conies." They do certainly resemble in habits the conies of Africa,-those described in proverbs as "feeble folk" which " make their houses in the rocks"; but in structure they are far away, and in reality are much nearer relatives of the rabbits, or of the guineapigs, whose wild brethren still dwell among the pumice and lava of the Bolivian Andes. They look, indeed, much like guinea-pigs, being about 


\section{The Wit of the Wild}

\&

the same size, having the same blunt nose, squat, rotund form, and small, creeping feet. Their ears are round, set close to the head and rimmed with white, and they have almost no tails at all. The varied colors of guinea-pigs are due to their long domestication, and the pikas do not resemble them in that respect, but are grayish above and yellowish-white on the lower parts.

Most of the mountain animals may go down into the protection of the forests when autumnal storms begin to blanket the peaks with snow, but some cannot get away. The siffleur, or mountain woodchuck, no longer sounds the wild, clear whistling that seems the voice of the mountain spirit, so eerie and disembodied is it, but, heavy with fatness, lounges into his snug burrow and goes to sleep. The few squirrels, mice and shrews, that dwell along the upper borders of the timber, seek warm retreats prepared in advance; the bears no longer climb the rocks, and even the white goat, whose favorite restingplace has been the middle of a glacial snow-field, now seeks some sheltered ravine-head for a winter hospice. Very few four-footed animals 


\section{The Haymakers of the Snow Peaks \\ \&}

bravely keep their residence while winter assaults and holds the icy heights. One of these is our little friend the pika; the other a neighbor of his, the sewellel, a creature much like a dimunitive beaver, but one which never takes to the water nor builds a dam, and has in place of a tail like a mason's trowel one like a very small and scanty whisk-broom. I shall have more to say of him presently.

In no season is the Alpine world more enticing than in early autumn. A carpet of exquisite late flowers is spread upon the softer ground: they are the same that in the valleys sway upon tall stems, but here form a mat close in the earth, for in the short summer of these heights nature has no time to waste on making stems and leaves. The slopes and ridges just above the dwarf trees that mark the limit of forest growth, are golden with ripened grass; and the bared crags overhead glitter upon their edges, but are richly purple in shadow. The sunshine is yellow and mellow, and an opalescent mist veils the peaks, near and remote, which shine in it like the ruins of mighty shells, now 


\section{The Wit of the Wild}

\&

silvery white, now palest blue, now rosy, and over all arches a perfect sky.

In this delicious weather, as you stroll about these gable-ends of the roof of the world, you constantly come upon bouquets of flowers, their stems all one way, laid side by side on some warm rock, and you wonder who has picked and arranged them so carefully yet left them to wither; and then you begin to see little heaps of grass and weeds standing in the sun and turning yellow and dry under its long, hot beams. There may be scores or hundreds of them.

If your curiosity led to observation you would presently discover that these were near the home of a colony of pikas, which lived in the loose slide-rock, finding their way in winding galleries far into its interior, where each family had a snug nest in some convenient hollow, and that these heaps of drying vegetation-tiny haystacks-were the gathered material of their winter stores.

They do not, like the whistlers, pass the winter in torpid sleep, nor is it possible for them either to seek or find any forage during the 


\section{The Haymakers of the Snow Peaks}

\section{\&}

cold season. Hence they must lay up stores, and plentiful ones. In this duty they show not only great industry, but much sagacity, the former being required, indeed, by the latter, for their harvest is a short and precarious one. They must not cut the grasses and flowering weeds too early, for then the juices are still copious in the stalks, and these would heat and ferment the plants when piled up, causing them to rot instead of to "cure." They dare not wait too long, for fear the plants may shed their nutritious seeds and wither, or even be lost altogether beneath burying snows or destructive gales. Hence it is an evidence of much judgment and great activity on the part of these little husbandmen that they are able to meet their requirements in the brief season-only a fortnight or so in later September-allowed them by their climate and circumstances. During this short harvest-time the pikas make their hay, stack it up in the sun to eure, and, when it is thoroughly dry, but not decayed, take it into their barns beneath the stones and store it as food for the long winter to come. 


\section{The Wit of the Wild \\ \&}

In doing this they keep a sharp eye upon the weather, in respect to which they seem to have remarkable foreknowledge. The pikas of Russia, which have much the same habit, but exist lower down on the mountain sides, so that they are better known to the people, are called by the peasants "weather wisers" and are depended upon as living barometers. The same faculty belongs to our "little chief," as the Northern Indians call him, and he turns it to good account.

Some day the barometer at your mountain camp will begin falling, although otherwise no sign of bad weather disturbs the serenity of the heights. But you will notice a sudden excitement and great activity on the part of your squeaking little friends among the rocks. All the afternoon, braving your presence with unwonted courage, they will toil at their work of carrying in their provender, and, though usually they go to bed at sunset, to-night you will hear them bleating and calling to one another as they hasten their harvesting until far into the night. Before morning gales and snow and 


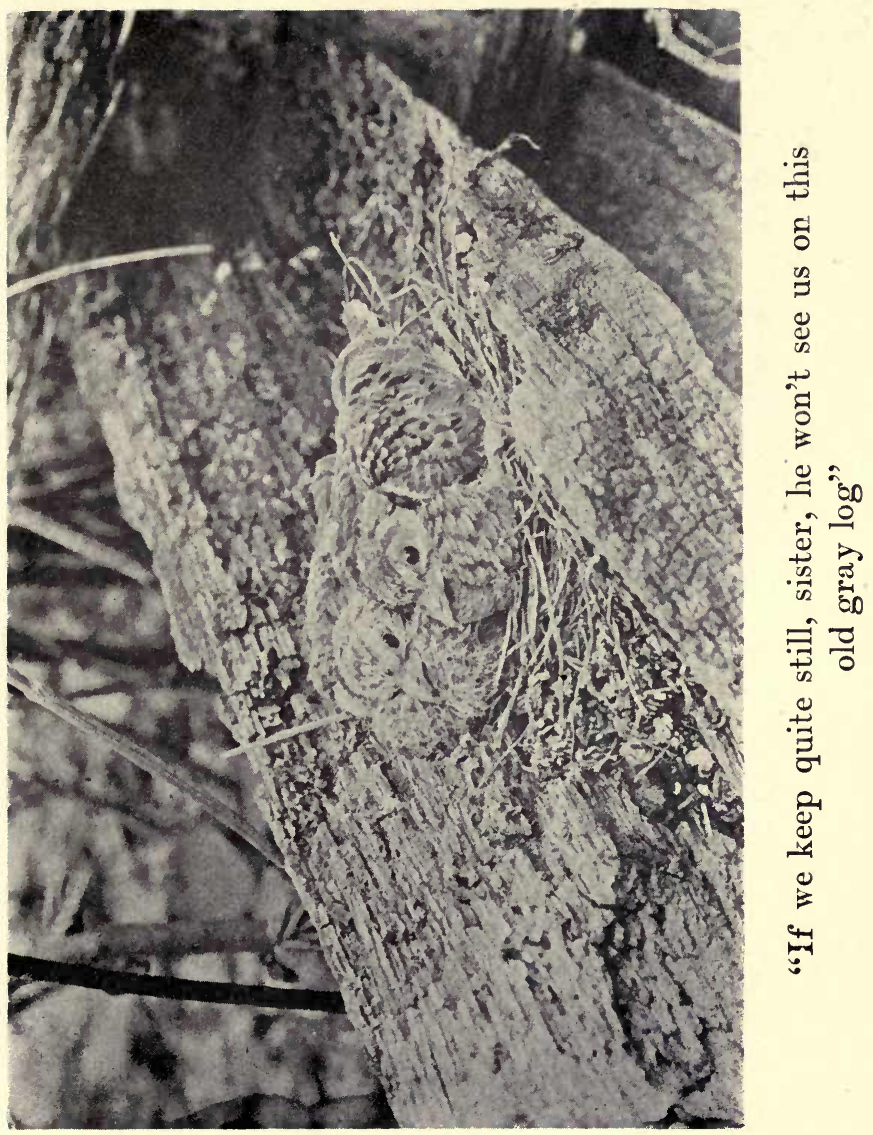





\section{The Haymakers of the Snow Peaks \&}

sleet will envelop the mountain, the first patrol of winter attacking it with a fierceness that seems an assault by all the boreal hosts. But whether you be prepared or not, the pikas have not been caught napping! Their provender is all safe in the underground barns.

An odder and less known animal, living near timber-line in the Coast ranges of Oregon and northward, is the one introduced to us a century ago by Lewis and Clark as the "sewellel,"-a name which involved one of those errors so easily and frequently made by explorers. It appears that the Chinook Indian's name for the animal itself was o-grwool-lal, but they called a robe made of its skins she-ral-lal, corrupted into "sewellel." That is, Lewis and Clark mistook the name of the garment for that of the animal. The Nisquallies, living along the shores of Puget Sound, called it shoret'l, as may be seen in some of our older books; and the white trappers soon dubbed the animal "mountain beaver," which was much closer to the truth than their names usually were.

In fact it is nearer to the beaver than to any. 


\section{The Wit of the Wild}

\&

other animal in structure, but is so generalized that some paleontologists believe it represents, better than any other existing species, the ancestral type from which the varied tribes of squirrels and squirrel-like rodents have descended. It stands in a group of its own,- - the Haplodontia.

The sewellel is about the size of a muskrat, and reddish-brown in color, with a very short, brush-shaped tail, very small eyes, and a warm, close fur, of which the Indians made much use, as also they did of that of the pika, the women fashioning baby-clothes and winter undergarments by stitching together these delicate pelts, as well as making of them blanket-like robes. All the mountain Indians are (or used to be) very fond of its flesh; and Dr. George Suckley, one of the earliest naturalists to investigate the fauna of the Columbia Valley, roasted one and "found it excellent, tasting much like chicken."

They are shy and cunning, however, and nowadays, at any rate, are trapped only with much difficulty; when chased by dogs, they fight so 


\section{The Haymakers of the Snow Peaks}

\section{\&}

well as to make a very respectable antagonist to the average terrier.

The sewellels live in wet places, where the ground is soft, rich and overrun with rank vegetation, " preferably," writes Dr. Merriam, " in springy, sloping ground, where their innumerable burrows are kept wet by the cold, trickling water." In fact, settlers complain that their burrows often start bad washouts in the hillsides, especially in clover-fields, a plant of which they are as fond as are the woodchucks. In such places they often exist in a numerous colony whose underground passages are connected in a neighborly way; and early in the morning a dozen or so may often be seen sitting at the entrances to their subterranean homes, and "whistling like prairie dogs," as one writer puts it. Long ago the Oregon people named them "boomers," in reference to the hollow tone of their voices.

These little folks, like the pikas and beavers of which they remind us, must store winter supplies, and in the late summer "they cut various plants, commonly rank or woody kinds, which 


\section{The Wit of the Wild \\ \&}

they gather and carry in bundles to their burrows or to places near by, where they spread them out to dry." They will climb a small bush some distance in order to cut off the tender upper twigs. These provisions vary with the locality, and what is there available. Twigs of thimble-berry, mountain-ash, salal, willow and other shrubs, whose bark they find edible, are common in the stacks; but most of all they gather brakeferns, sometimes a bushel or more in a single heap over or close to the principal mouth of the burrow. After these have been thoroughly dried and cured in the sun they are dragged into the innermost burrows, and used to sustain the very simple requirements of a life reduced to inertness by having very little to do or think about during the long months of imprisonment by cold and snow. They are very fat and sleek when they go in in the fall, but look decidedly seedy when they reappear in the spring.

How completely the showt'ls hibernate it is hard to determine: probably more than do the conies, and apparently far more than do their neighbors of the upper edge of the woods,- 


\section{The Haymakers of the Snow Peaks \&}

the Sierra pocket-gophers. Where the latter are numerous, as on the higher slopes of Mount Shasta, you may see, when the snow has gone off in the spring, hundreds of little cake-like elevations of soil which have been pushed up underneath its crystal covering. These deposits show that all winter these small but hardy ground-squirrels are burrowing about beneath the frost in search of tuberous roots and other food, and every now and then have poked their heads above ground to push the earth out of some newly bored tunnel, or to investigate the condition of the world and the progress of events. 


\section{A Kitten at School}

\section{\&}

MUE "back yard" of a metropolitan house does not afford much material for 1 natural history study, except, perhaps, to the insect hunter; but I have been amused and interested in watching the education and recreation of a kitten which is going on in my neighbor's little area.

It has all been seen before, no doubt, a thousand times; but it struck me that not many young animals had so much fun mixed up with their schooling as a kitten gets. Its school is, in fact, a sort of kindergarten. This old cat plays with her kitten in the most patient way, when, I have no doubt, she'd much rather be quietly asleep on the warm flagstone by the kitchen window.

Now few animals do that. The youngsters of all sorts frolic by themselves. I have seen a family of four wolf-pups rollicking at the $\rightarrow 262$ sc 


\section{A Kitten at School \\ \&}

door of their rocky den in the Green River sandhills of Wyoming, exactly as you may see a parcel of small dogs scrambling over one another and pretending to bite. Most adult beasts have some sense of humor, and many a large degree of playfulness. Who that has ever watched the monkeys in Central, or Schenley, or Lincoln parks, or in any other menagerie, can doubt that? Squirrels spend much of their time in pure play, as do all agile animals. But the instances are rare, as I have said, where the old ones seek to amuse the young, or join in with them in real sport.

I remember once lying upon the brink of a very lofty cliff, in northern Wyoming, watching for an hour or two the extraordinary agility and jollity of a lot of bighorn kids. They were racing up and down steep snowbanks, leaping over and dodging each other among the rocks like children playing tag, while the old rams and ewes lay curled up in dry spots, or fed quietly upon the fresh herbage of the alpine meadow, without paying the least attention to the games. 


\section{The Wit of the Wild}

\section{\&}

But my neighbor's tabby is evidently of the opinion that all work and no play will make of her Jack a dull cat; and there is no room in the city of New York for a dull cat! Its wits must be as sharp as its claws; it must be armed cap-àpie, so to speak, if it is to hold its own in the nocturnal competition of the back fence. What but the brightest wits would enable a cat to do as the one in the following story, related by Romanes, did?

An English family had been accustomed during a season of severe cold to throw crumbs from the breakfast-table to the birds, and presently their cat got into the habit of waiting in ambush, in the expectation (often realized) of obtaining a hearty meal from one or two of the assembled sparrows. After a time the servant neglected the practice of throwing out the crumbs, whereupon the cat was observed by several persons to get crumbs and scatter them on the grass with the obvious intention of enticing the birds anew. Dr. Romanes says he has no reason to doubt the accuracy of this narrative; and furnishes in corroboration other simi- 


\section{A Kitten at School}

\section{\&}

lar incidents, in one of which a cat scratched up and laid upon the surface decoy-crumbs that had been concealed by a slight fall of new snow.

Only two blocks away from where I write there lived until recently a tomcat of great size and marked intelligence, who once saved the house from burglary, by recognizing the intruder as a stranger improperly in the house, and thereupon making such a rumpus as to arouse the family. "If left in the yard," says an account of him in the New York Times, " this smart animal would not stand at the door and mew, as most cats would, but always reached up, and with his fore paws turned the doorknob and passed into the house."

The comprehension of mechanical appliances like that is often seen in cats. I have read of one that quickly learned to open a hinged window that was fastened with a swivel catch. Many instances are recorded of cats opening doors by springing upon the thumb latch. But success here involves more than the mere depressing of the thumb-piece of the latch, although this act alone shows close observation 


\section{The Wit of the Wild}

ริ

and reasoning on the part of the animal; for the cat at once discovers that it must, by scratching with its hind feet against the posts, or by throwing its weight against the door, push the door far enough to prevent the latch falling into the guard again, if it expects to accomplish its object. A good many smart cats have "caught on" to the fact that the ringing of a door-bell or the bell-pull in a room will summon a servant, who will understand that they want to be fed. This is quite different from the case where a captive animal is taught to ring a bell arranged for it, as is sometimes done. In the former instance the cat observes that the pulling of that bell-handle makes noise, which is followed by the appearance of a servant, who has the means to gratify its wants. It reasons: "If somebody opens the door I can get in; when men pull that handle somebody does open the door; the same result will follow if I pull the handle; therefore I will do so."

The most characteristic feature in the feline nature, probably, is the practice of keeping its half-dead victims under its paws and recaptur- 


\section{A Kitten at School}

\section{\&}

ing them again and again, as they attempt to escape, before finally giving them their quietus.

Many explanations of this have been given, none of which seem to me very satisfactory. Mr. Romanes refers it to an endowment of extra cruelty in the feline nature, which seems to me simply begging the question. I am inclined to refer it to the animal's enjoyment of playits living victim is an active toy. Few cats ever get too old to frolic with a ball. I have seen a bulldog become enraged almost to the point of insanity over a struggle with a stone globe about the size of a football. It is probable the animal thinks it alive. Tigers and lions, when they are enraged, or alarmed, and strike down a hunter, do not hesitate about killing him at once-they are in no mood for play; but domestic cats will sometimes catch animals they do not like to eat just for the fun of it. An instance in point was reported in Science Gossip (July, 1876), as follows: "We had a cat which was very fond of playing with frogs. She would hunt about the garden until she unearthed one, and pat it on the back until it leaped away 


\section{The Wit of the Wild \\ \&}

with a loud squeak. I have of ten observed her doing this, but on no occasion did she attempt to eat the frog, and I never could discover that she injured it in the least."

Moreover, it should be observed that this characteristic feline practice seems to be something a young cat is taught to do by its parents - at any rate that seemed to be the intent of what I saw going on over the fence this morning. The mother-cat brought out a bone to which considerable meat was attached, and laid it down. The kitten made a dash at it, but was driven off. Then the old cat approached the bone and began to toy with it, snatching at it with its fore paws, hopping about, and generally behaving as nearly as possible as if the bit of meat were a living prey. After a little the cat stopped this and lay down at a distance, whereupon the kitten approached and clumsily imitated its mother's action. A second time the scene was rehearsed, and only after this lesson was Kitty allowed to eat her meal as she pleased.

Inherited aptitude for its special training is 


\section{A Kitten at School}

\section{\&}

undoubtedly there, but the number of things which an animal would do when it grew up, without the training by and imitation of its parents in its youth, is, to say the least, much smaller than it used to be considered. 


\section{Catching Menhaden off Montauk}

\section{\&}

NE day a fishing-steamer came in and its captain invited me to go with him, in search of menhaden, off Montauk Point.

This promised to be good fun, and I gladly accepted the bid. That night we ran across the eastern throat of Long Island Sound, rounded Point Judith in a lively breeze, which set the little vessel dancing gayly, and next day were back again, anchored in Gardiner's Bay. The wind was wrong, or something else, I forget what, but at any rate we went into Greenport that night, and postponed fishing until the following morning. I strolled about the pretty Long Island village until bedtime, and then went aboard, for we were to be off at daylight.

What an exquisite night it was! The air was perfectly calm, the moon just risen, and no sound was to be heard save the ticking of that mighty time-piece, the tide, as its wavelets swung gently 


\section{Catching Menhaden off Montauk \\ \&}

back and forth under the weedy piers, or divided against the sharp prows of the smacks. There was light enough to show the spars and ropes of every craft in the harbor, and all lay as motionless as though fixed in rock rather than floating on liquid.

I "turned in " upon a sofa in the captain's cabin; and when I emerged, after what seemed an hour's pounding on my door by the chuggety-chugging engine, we were far down Gardiner's Bay again.

Last night the unruffled water was like bronze; now, under the soft silvery haze of the morning, the dancing surface became frosted silver, opaque and white save where the early sunbeams, striking through the mist, were reflected from the crests of the ripples in glancing ribbons of light. Shelter Island was an indistinguishable mass far astern; Long Beach light had ceased to twinkle; Orient Point was hidden in haze; Plumb Island, where eagles used to make their metropolis, and many fish-hawks now live, nesting on the ground with the gulls, was only a low bank of blue; Gull Islands could not be seen at all; and I only knew that Little Gull was there from the dot in the 


\section{The Wit of the Wild}

\section{\&}

horizon made by its lonely lighthouse, and an occasional gleam imagined to be the surf breaking on the reefs at the Race. All this was northward. Southward the wooded bluffs of Gardiner's Island, with its natural breakwater and lighthouse, like a long arm reaching out between the outer and the inner waters, limited the view. But this was soon left behind, and as the deep indentation of Napeaque came into view, the steamer's head was turned southeastward, toward Montauk, which, in the growing light, now stood out plain in every bleak feature of sandy dune and treeless moor.

Now a very sharp lookout must be kept for fish, and after the substantial breakfast in the forecastle, I climbed half way up the shrouds. Even then I could not look across Montauk, but could easily see two great ponds of fresh water, which nearly serve to make an island of the Point. One of them, Fort Pond, was once a scene of sanguinary Indian warfare between the Montauks and Narragansetts, the latter being beaten only by help from the Shelter Island Indians, who drove the invaders to their canoes. At that

\section{of 272 sco}




\section{Catching Menhaden off Montauk \&}

time the Montauks were the most powerful of all the tribes on Long Island, and appear to have been unusually upright savages. Their country, Montauk Point, was once clothed with an abundant forest, but the clearing, which took place a century and a half ago, has never been replaced by a new growth, and the whole space is now a wild waste of desolate grass, almost uninhabited, and rarely visited except by gunners and cranberry-pickers.

Off Culloden Point the lookout excitedly announced, "Fish off the port bow!" The captain seized his glass and scanned the water. So did I.

"There's a big bunch," he shouts. "Watch 'em flirt their tails! Good color! See how red the water is?"

"Oh, yes, to be sure," I cry. "By Jove, that's a good color!"

My vacant face must have belied my words, but he didn't notice it. He was shouting:

"Lower away the boats! Stand by to ship the nets!" furiously ringing signals to the engineer, giving hasty orders to the wheelsman, ensconcing himself in a pair of oilskin trousers so capacious 


\section{The Wit of the Wild \\ \&}

I half expected he would disappear altogether; and so, amid the roar of escaping steam, the creaking of davit tackle, the laughing excitement of the crews, and the rattle of rowlocks, I tumbled head-foremost into a boat, and the steamer was left behind. Now the flirting of tiny tails was plainly visible, but I must confess that I did not learn to distinguish the reddish hue which indicates a school of these fish until much later in the day.

The two large boats side by side were sculled rapidly toward the shore where the fish were seen, the forward part of each boat piled full of the brown seine, which extended in a great festoon from one to the other. There were four men in each boat, all standing up, and in our red shirts and shiny yellow oilskin overalls, we must have made a pretty picture on that sunny morning. Close by was a pound net, where a porpoise was rolling gayly, notwithstanding his captivity, but by maneuvering we got the "bunch" turned away from it and well inshore where the water was not too deep. At last we were close to them, and now came a scene of excitement. 


\section{Catching Menhaden off Montauk \&}

"Heave it!" yelled the captain, and in each boat a sailor whose place it was worked like a steamengine, throwing the net overboard, while the crews pulled with all their muscles in opposite directions around a circle perhaps a hundred yards in diameter, and defined by the line of cork buoys left behind, which should inclose the fish. In three minutes the boats were together again, the net was all paid out and an enormous weight of lead had been cast over, drawing after it a line rove through rings along the bottom of the seine. The effect, of course, was instantly to pucker the bottom of the net into a purse, and thus, before the bunkers had fairly apprehended their danger, they were caught in a bag whose invisible folds held a cubic acre or two of water. "Bunker" is one of the many so called names of the fish known in books as menhaden.

This was sport! None of the fish were to be seen. Every fin of them had discreetly sunk to the bottom. Whether we had caught ten or ten thousand remained to be proved. Now, lifting such a net is no easy job. The weight of nearly ten thousand square yards of seine, alone, is im- 


\section{The Wit of the Wild}

\section{\&}

mense, but when it is saturated with cold seawater, and held back by the pushing of thousands of energetic little noses, to pull it into a rocking boat, implies very hard work. However, little by little it came over the gunwales, the first thing being to bring up the ponderous sinker and ascertain that the closing of the purse at the bottom had been properly executed. Yard by yard the cork line was contracted, and one after another frightened captives began to appear, some folded into a wrinkle of the twine, or caught by the gills in a torn mesh (and such were thrown back), until at last the bag was reduced to only a few yards in diameter, and the menhaden were seen, a sheeny, gray, struggling mass, which bellied out the net under the cork line and under the boats, in vain anxiety to pass the curious barrier which on every side hemmed them in, and in leaping efforts to escape the crowding of their thronging fellows. How they gleamed, like fish of jewels and gold! The sunshine finding its way down through the clear green water seemed not to reflect from their iridescent scales, but to penetrate them all, and illumine their bodies from 


\section{Catching Menhaden off Montauk}

\section{\&}

within with a wonderful changing flame. Gleaming, shifting, lambent waves of color flashed and paled before my entranced eyes-gray, as the fishes turned their backs, sweeping brightly back with a thousand brilliant tints as they showed their sides-soft, undefined, and mutable, down there under the green glass of the sea; while, to show them the better, myriads of minute medusæ carried hither and thither glittering little phosphorescent lanterns in gossamer frames and transparent globes.

All possible slack having now been taken in, the steamer approaches, and towing us away to deeper water, for we are drifting toward a lee shore, comes to a standstill, and the work of loading begins. The cork line is lifted up and made fast to the steamer's bulwarks, to which the boats have already attached themselves at one end, holding together at the other. This crowds all the bunkers together in a mass between the two boats and the steamer's side, where the water boils with the churning of thousands of active fins. A twentyfoot oar is plunged into the mass, but will not suffice to sound its living depths. Then a great 


\section{The Wit of the Wild \\ \&}

dipper of strong netting on an iron hoop is let down by tackle from the yard-arm, dipped into the mass under the guidance of a man on deck who holds the handle, the pony engine puffs and shakes, and away aloft for an instant swings a mass of bunkers, only to be upset and fall like so much sparkling water into the resounding hold.

"How many fish does the dipper lift out at once?"

"About a thousand."

"Very well. I will count how many times it goes after a load."

But I didn't. I forgot it in looking down the hatchway.

The floor of the shallow hold was paved with animated silver, and every new addition falling in a lovely cataract from far overhead, seemed to shatter a million rainbows as it struck the yielding mass below and slid away on every side to glitter in a new iridescence until another myriad of diamonds rained down.

If you take it in your hand, the moss-bunker presents itself as an ordinary-looking fish, and you do not admire it; but every gleaming, fiery 


\section{Catching Menhaden off Montauk}

\section{\&}

tint that ever burned in a sunset, or tinged a gemcrystal, or painted the petals of a flower, was cast in lovely confusion into that dark hold. There lay the raw materials of beauty-the gorgeous elements out of which dyes are resolved: abstract bits of lustrous azure and purple, crimson and gold, and those indefinable greenish and pearly tints that make the luminous background of all celestial sun-painting. As the steamer rolled on the billows, and the sun struck the wet and tremulous mass at this and that angle, or the whole was in the half-shadow of the deck, now a cerulean tint, now a hot brazen glow, would spread over all for an instant, until the wriggling mixture of olive backs and pearly bellies and nacreous sides, with scarlet blood-spots where the cruel twine had wounded, was buried beneath a new stratum.

"How many?" I asked, when all were in.

"Hundred and ten thousand," replied Captain Hawkins. "Pretty fair, but I took three times as many at one haul last week."

"What are they worth?"

"Oh, something over a hundred dollars. Hard a-starboard! go ahead slow." 


\section{The Wit of the Wild}

\&

Then the labor of the engines drowned the spat, spat, spat, of the myriad of restless little tails struggling to swim out of their strange prison, while I climbed to the masthead to talk with the grizzly old lookout, who had been round Cape Horn thirteen times, yet did not think himself much of a traveler.

That day we caught 250,000 fish and made a round trip of a hundred miles, going away outside of Montauk Point, where it was frightfully rough after a two days' easterly gale. Pyramids and ridges of water, huge and irresistible, green as liquid malachite, traveled in turbulent haste to magnificent destruction on the beach, where sunlit clouds of spray were floating dense and high, and the roar of the surf came grandly to our ears wherever we went, Yet the difficulties were none too great for these hardy fishermen, who balanced themselves in their cockleshells, and rose and sank with the huge billows, without losing their hold upon the seines, or permitting a single wretched bunker to escape. 


\section{Gull Dick}

\section{\&}

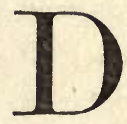

ICK was a herring-gull that first began to be noticed around the lightship which warns vessels away from Brenton's Reef, - a ledge of dangerous rocks two miles off the harbor of Newport, Rhode Island,a place of perils that will long be remembered by the gallant story of "Grace Darling" (Ida Lewis), who lived there in the little lighthouse she made famous.

As the lightship rolls and sways and tosses in the midst of never-quiet surges, her crew in their loneliness observe keenly many things that on land would escape their attention. It was thus that Dick came to be noticed one day among a flock of lively companions wheeling and curveting over the waves that rose and fell upon the cruel ledges-noticed day after day, because he seemed so much older and more feeble than his younger and gayer companions. 


\section{The Wit of the Wild \\ \&}

The sailors began to toss bits of food where he could snatch them up before some rival could get ahead of him, and Dick soon understood the game and was ready to play his part.

This went on for twenty years, but the crew of the lightship, changing year by year, passed along the tradition to the new hands, so that although by this time not a man was left of those who had first known the bird, yet all were his friends, and looked for his arrival as eagerly, perhaps, as he anticipated his return to the place where he was fed.

All our gulls are now winter visitors to the southern New England coast. Originally herring-gulls bred there on the outer islets, but one of the bad effects of civilization has been to exterminate the breeding colonies or drive them to more thinly settled northern shores, to lay their eggs and rear their young in security.

Dick was never seen in the summer, therefore, but with unfailing regularity on some fine morning in the first week of October he would reappear-always in the morning, for these birds perform their migratory journeys mainly at night. 


\section{Gull Dick}

\section{६}

Nobody could say where he had been, of course; but he almost always showed signs of wear and tear, as if from contests with gales that had torn feathers from wings and tail, and seemed tired and hungry, as if a very long flight had just been finished. No wonder, then, that he came straight to the lightship, and hovered about it in pleased expectation of rest and the full breakfast that never failed him.

One day in 1891 an ornithologist, Mr. George H. McKay, discovered what these good sailormen had known for twenty years, and straightway the comings and goings of Gull Dick began to be regularly reported and discussed in The $A u k$, quite as if he were a real Newport "swell."

Every morning at sunrise, when the great lanterns at the masthead were lowered, Dick would take it as a signal, and be seen flying steadily toward the little vessel from the rocks, two miles away, where he had spent the night roosting in some snug crevice. If now and then he was not in sight, one of the crew had only to call or whistle a minute or two, when the knowing bird would appear, and wait on the 


\section{The Wit of the Wild \\ \&}

alert for the breakfast soon to be tossed to him.

Other gulls would come, too, but none would ever approach so near as Dick, although even he never alighted upon the vessel nor allowed himself to be handled. He liked boiled pork best, but did not object to fish; and it was amazing to see the famished eagerness with which, in the first few days of the season, the bird would eat, gulping down whole six or eight pieces each the size of a hen's egg.

I am sorry to say that this voracity was not altogether hunger, but partly greediness; for Dick would usually do his best to keep any other gull in the neighborhood from getting not only what was meant for him, but morsels thrown to his companions, "making the greatest possible fuss," says the captain, "if one of the other gulls attempted to secure an occasional piece." Once, he relates, Dick seized an aggressive rival by the neck and tore out its feathers until the poor creature was glad to get away with his life.

This, I fear, is a way the gulls have all over $\rightarrow 284$ so 


\section{Gull Dick}

\section{६}

the world. They are social creatures rather from motives of economy than of good-will, I suspect, for many eyes can sweep a range of beach or tide-flat or a space of water better than a single pair; and when one discovers any food his actions will at once let the rest know of it, and then there is a rush, for at the gulls' table the rule is first come, first served.

Gulls feed on anything and everything eatable, apparently, and many go far inland for food at certain times; but carrion and fish thrown up on the beach or embayed in some litthe tide-pool, sandworms, small crabs and mollusks, form their principal fare. The floating carcass of a whale is always covered with them; and the garbage-scows that go out from the harbor of New York to throw the refuse of the city into the ocean are always accompanied in winter by so great a cloud of these birds that the scows themselves are sometimes almost invisible.

They do not catch living food by diving after it, or chasing it under water, as do some seabirds, but trust to the surface to supply them, 


\section{The Wit of the Wild \\ \&}

pouncing down in a beautiful curve when they espy anything eatable, and deftly snatching it up without actually touching the water. Where time and place favor they will "run about the fields like rooks, busying themselves with the capture of insects, slugs and worms"; and will even catch mice and small birds if they can, and devour them-bones, fur, feathers and all. They may even be taught to live wholly on grain, and in such cases the stomach is modified into an organ closely like a fowl's gizzard.

The habit of rough warfare has developed a great deal of courage in the bird, which will fight bravely in defense of its nest or young, and often boldly assails a person who has just shot a companion.

That gulls are keen-witted is plain not only to one who watches them in freedom, but from their behavior as pets. Various kinds have been easily domesticated, and this is in itself a testimony to intelligence, for it is not easy to make a pet of a stupid creature.

All accounts agree that captive gulls know and take an interest in those who show them at- 


\section{Gull Dick}

\section{\&}

tention; and that if they fly away they are pretty sure to return again and again, and perhaps will bring a mate or young ones with them.

In the light of these facts the acquaintance between the men of Brenton's Reef lightship and Gull Dick is no longer singular, although it remains interesting. All winter he would linger about the lightship, taking the raising of the lanterns as a signal to come and get his supper, after which he would fly away to his customary roost on Beaver's-tail until sunrise.

About April 6th he would be seen for the last time that season, usually remaining until nightfall of the last day. "It would seem," Captain Fogarty records for 1892, "that Dick is inclined to have company during his migration this time, for he brought another gull with him to jointly partake of the supper provided, then both went away together." In 1894, his twentythird return, a companion came with him, but Dick would not let him share even the first breakfast; and in 1895 he went away again, attended by a young gull, "after a hearty supper." 


\section{The Wit of the Wild \&}

On October 2, 1895, Dick appeared for the twenty-fourth and last time, and instead of being ragged and torn, as usual, he now looked sleek, had all his proper feathers, and was in excellent spirits, fighting off every attempt to share the lightship's bounty. After braving all the winter storms, he said good-by again on April 7, 1896, and has not since been seen. I dare say Gull Dick is dead. 



\section{DAY USE}

RETURN TO DESK FROM WHICH BORROWED

BIOLOGY LIBRARY

\section{TEL. NO. 642-2532}

This book is due on the last date stamped below, or on the date to which renewed.

Renewed books are subject to immediate recall.

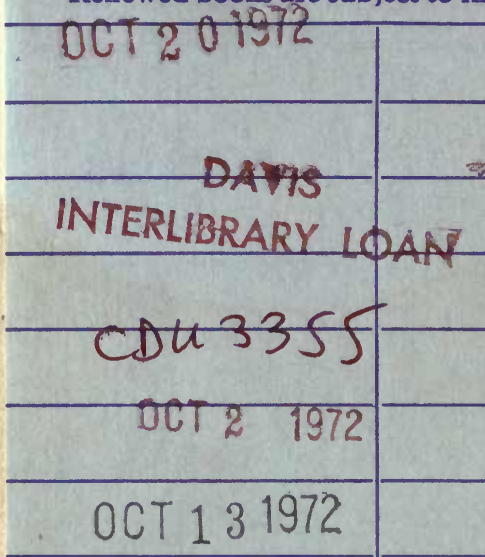


